\title{
Quarterly Sampling of the Wetlands Along the Old F Area Effluent Ditch: August 1994
}

by

C. L. Cummins

Westinghouse Savannah River Company

Savannah River Site

Aiken, South Carolina 29808

K L Dixon

Westinghouse Savannah River Company

DOE Contract No. DE-AC09-89SR18035

This paper was prepared in connection with work done under the above contract number with the U. S.

Department of Energy. By acceptance of this paper, the publisher and/or recipient acknowledges the U. S.

Government's right to retain a nonexclusive, royalty-free license in and to any copyright covering this paper, along with the right to reproduce and to authorize others to reproduce all or part of the copyrighted paper.

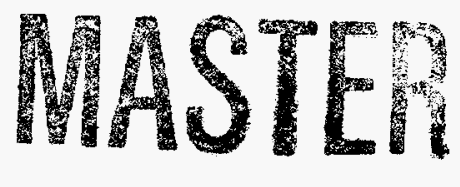


WSRC-TR-94-0543

Rev 0

\section{Quarterly Sampling of the Wetlands Along the Old F-Area Effluent Ditch: August 1994 ${ }^{(\mathrm{U})}$}

Westinghouse Savannah River Company

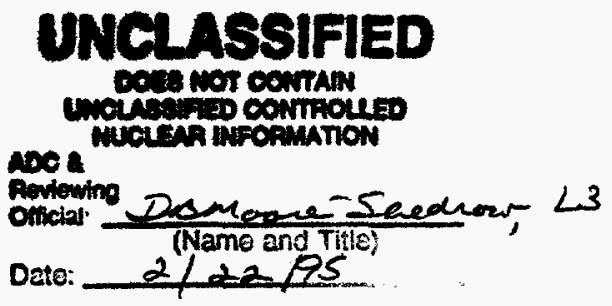

Savannah River Site

Aiken, SC 29808

Prepared for the U.S. Department of Energy under contract no. DE-AC09-89SR18035 


\section{Disclaimer}

This report was prepared as an account of work sponsored by an agency of the United States Government. Neither the United States Government nor any agency thereof, nor any of their employees, makes any warranty, express or implied, or assumes any legal liability or responsibility for the accuracy, completeness, or usefulness of any information, apparatus, product, or process disclosed, or represents that its use would not infringe privately owned rights. Reference herein to any specific commercial product, process, or service by trade name, trademark, manufacturer, or otherwise does not necessarily constitute or imply its endorsement, recommendation, or favoring by the United States Government or any agency thereof. The views and opinions of authors expressed herein do not necessarily state or reflect those of the United States Government or any agency thereof.

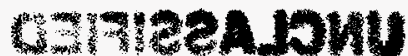

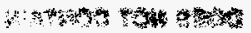 \\ 6.

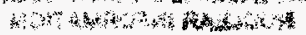 \\ ;


WSRC-TR-94-0543

Rev 0

August 1994

\title{
Quarterly Sampling of the Wetlands Along the Old F-Area Effluent Ditch: August 1994(U)
}

\author{
C. L. Cummins and K. L. Dixon
}

Prepared for the U.S. Department of Energy under contract no. DE-AC09-89SR18035 


\section{DISCLAIMER}

Portions of this document may be illegible in electronic image products. Images are produced from the best available original document. 


\title{
Quarterly Sampling of the Wetlands Along the Old F-Area Effluent Ditch: August 1994 (U)
}

\author{
C. L. Cummins and K. L. Dixon \\ Savannah River Technology Center \\ Westinghouse Savannah River Company \\ Aiken, SC 29802
}

\section{Executive Summary}

In August 1994, well point water and near-surface water samples (i.e., bucket samples) were collected to further characterize tritium and volatile organic compounds (VOC) in the wetlands along the old F-Area effluent ditch south of 643-E (old burial ground). The August sampling event was the third in a series of eight events. Groundwater flow paths suggest that compounds detected in water table wells around 643-E migrate towards the old F-Area effluent ditch and Fourmile Branch. Recent analytical results from well point and near-surface water sampling in the wetlands that comprise the old F-Area effluent ditch have shown that tritium and small quantities of VOCs are outcropping in the area. For this study, seven locations along the old F-Area effluent ditch were selected to be sampled. Well point samples were collected from all seven locations and near-surface water samples were collected at four locations.

Results of the August 1994 sampling event further support findings that tritium and volatile organic compounds originating from 643-E are outcropping in the wetlands near the old F-Area effluent ditch. Four different analytes were detected in the well points at least once at concentrations greater than the method detection limit. These analytes included 1,2-dichloroethylene (total), tetrachloroethylene, trichloroethylene, and tritium. Each analyte was detected at least once at concentrations above the Primary Drinking Water Standards (PDWS; EPA, 1991) or the Maximum Contaminant Levels (MCL; EPA, 1993a and b) list.

Five analytes, 1,2-dichloroethylene (total), tetrachloroethylene, trichloroethylene, tritium, and vinyl chloride were detected at least once in the bucket samples at concentrations greater than the method detection limit. Four of the five analytes-1,2-dichloroethylene (total), trichloroethylene, tritium, and vinyl chloride-were detected at concentrations above the limits established by the PDWS or MCL at one or more bucket locations.

A secondary objective of this project was to compare VOC concentrations between the well points installed to depths of 6 to $8 \mathrm{ft}$ and the near-surface water sampling devices (buckets) installed to depths of 1 to $2 \mathrm{ft}$. Based on differences in tritium concentrations at each location, it was determined that the sampling devices intercepted different groundwater flow paths. This negated direct comparison of analytical results between devices. However, when VOC concentrations measured at each well point and bucket location were normalized, based on the percent differences observed in tritium concentrations at that location, the resulting well point and bucket VOC concentrations were comparable in most cases. These results are consistent with the results from the three previous sampling events, and suggest that volatilization losses of VOCs from the buckets may be negligible. Since the results from the two sampling methodologies are not directly comparable, further sampling of the buckets is not planned.

The information in this report was developed during the course of work under Contract No. DE-AC0989SR18035 with the U. S. Department of Energy. 
WSRC-TR-94-0543 


\section{Introduction}

The Radioactive Waste Burial Grounds are central waste storage sites used for disposing of onsite and offsite radioactive and nonradioactive wastes (Jaegge et al., 1985). The burial grounds are divided into three areas: Building 643-E (old burial ground), which received wastes from 1952 through 1972; Building 643-7E, which has been receiving wastes since 1969; and Building 643-28E which is a closure area within Building 643-7E and is termed the Mixed Waste Management Facility (MWMF) (Jaegge et al., 1985). The sampling zone along the old F-Area effluent ditch receives discharge from shallow groundwater flowing under the southwest corner of 643-E.

Detectable quantities of organic compounds have been measured in the groundwater beneath 643-E (Hoeffner et al., 1985; Hoeffner, 1984). Potential sources of the organic compounds in 643-E were identified as liquid scintillation wastes, spent solvents, decontamination reagents, and waste oils (Hoeffner et al., 1985) as well as decomposition of humic substances. Hoeffner et al. (1985) performed in-depth analysis of semi-volatile organics (using GC/MS) on ten wells in 643-E that consistently contained measurable amounts of total organic carbon. One other well included in the study was located in close proximity to 643-E near the site of previous decontamination operations. From these 11 wells, more than 50 organic compounds were detected. Detected aromatic volatile organic compounds included benzene, toluene, phenol, and naphthalene, among others. Hoeffner et al. (1985) indicated that the primary source of these four compounds was liquid scintillation wastes.

Many water table wells (BGO series, Group D) near 643-E are sampled quarterly as part of the SRS groundwater monitoring program. These wells are sampled for all or part of the Resource Conservation and Recovery Act (RCRA), Appendix IX analyte list. Chlorinated VOCs are routinely detected in several water table wells, particularly in the southwest corner of 643-E. These compounds, which include 1,1-dichloroethane, 1,2-dichloroethylene, 1,1dichloroethylene, tetrachloroethylene, trichloroethylene, and vinyl chloride (EMS, 1993), originate from or are biodegradation products of wastes buried in 643-E (i.e., organic degreasers). Tritium is also routinely detected in the wells and originates primarily from spent melt crucibles in 643-E.

Groundwater flow paths for Aquifer Zone IIB2 (WSRC, 1991) suggest that compounds detected in the water table wells around 643-E would migrate towards the old F-Area effluent ditch and Fourmile Branch (FMB) (Figure 1). As the flow paths approach FMB, shallow groundwater outcrops into FMB and its wetlands including those along the old F-Area effluent ditch. Recent analytical results from near-surface water sampling in the wetlands that comprise the old F-Area effluent ditch have shown that tritium and small quantities of VOCs are outcropping in the area. Detected organic compounds include toluene, total 1,2-dichloroethylene, vinyl chloride, and trichloroethylene (Dixon, 1993a and b). Based on the regional groundwater flow patterns for the water table aquifer in this area, it is believed that these constituents are migrating from beneath $643-\mathrm{E}$ and outcropping into the wetlands. This hypothesis is further corroborated by tritium and conductivity results from the quarterly tritium survey (Dixon and Rogers, 1993a) conducted in the wetlands of FMB down gradient of the F- and H-Area seepage basins. Waste discharged into the Fand H-Area seepage basins, in which 643-E is located between, contained high levels of salt ions compared to waste stored in 643-E. Using a Spearman rank correlation, Dixon and Rogers (1993a) found a strong correlation between tritium activities and conductivity values at locations where wetland water was being influenced by the contaminant plumes migrating from the F- and $\mathrm{H}$-Area seepage basins. However, conductivity values measured in the wetlands south of 643-E were at or near background, even at locations where tritium activities were more than $50,000 \mathrm{pCi} / \mathrm{ml}$ (Dixon and Rogers, 1993a); no correlation exists between tritium activities and conductivity values for this wetland. These results are consistent with previous studies (Haselow et al, 1990; Dixon and Rogers, 1993b) and suggest that tritium and VOC concentrations measured in the wetlands south of 643-E originate from wastes buried in 643-E.

The purpose of this study is to further characterize tritium and VOC outcrops in the wetlands south of 643-E along the old F-Area effluent ditch. This project differs from previous sampling events in that well points (less than $10 \mathrm{ft}$ below the soil surface) are used to sample the shallow groundwater. In the past, a relatively simple near-surface water sampling methodology has been employed to collect samples from the wetlands. Using the near-surface water sampling methodology, a small hole is excavated using a shovel at each sampling location. A five gallon plastic bucket with the sides cut out is then installed in the hole to a depth of about $1.5 \mathrm{ft}$. After installation, these buckets are covered with a plastic lid. Twenty-four hours later, after water has seeped into the buckets, the water samples are collected. This methodology, while simple, provides good analytical results for a wide range of parameters at a reasonable cost for many sampling locations. Using the well point sampling methodology, the shallow well points are installed to a depth of 6 to $8 \mathrm{ft}$ and are sealed except for a small well vent to accommodate changes in air pressure inside the well casing resulting from fluctuating water levels. This should provide additional assurance that representative VOC samples are collected. For the past two sampling events, a secondary objective to characterizing VOC and tritium contamination in the wetlands has been to compare the two sampling methodologies to determine 
any differences. The goal was to show that the results from both methodologies are comparable and that it is not necessary to use the more expensive well point sampling methodology when VOCs are of interest on future projects of this type (i.e., either the near-surface water or shallow well point samples may be used to evaluate outcropping VOC plumes). The results of this comparison are discussed later in this report. 


\section{Old F-Area Elffluent Ditch}

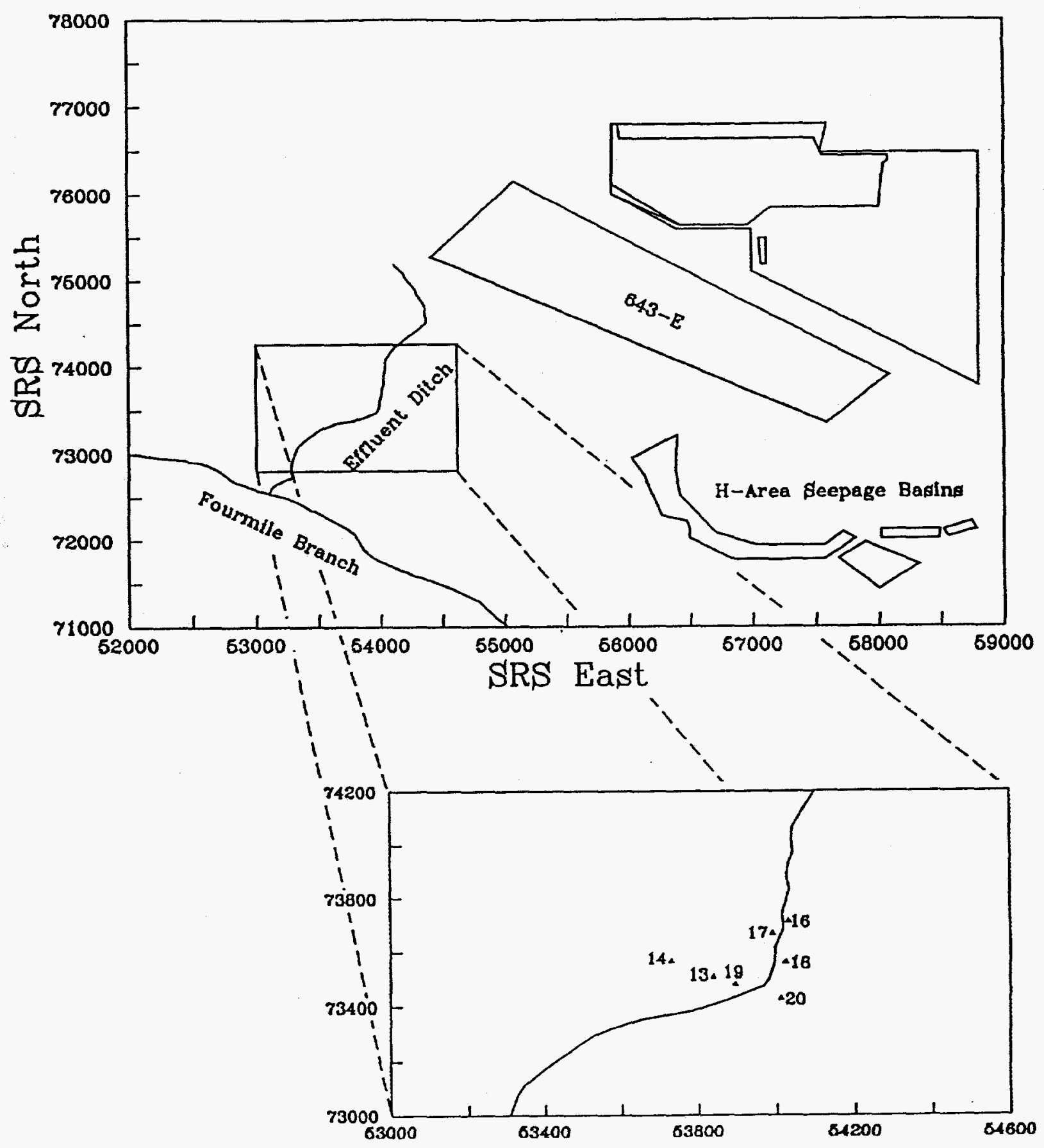

Figure 1 Sampling Locations Along the Old F-Area Effluent Ditch. (All locations are prefixed by "FHB0"). 
WSRC-TR-94-0543 


\section{Objectives}

The objectives of this report are to:

- $\quad$ present the results of the August 1994 sampling event in the wetlands south of 643-E along the old FArea effluent ditch

- $\quad$ compare, where possible, these results to related standards (Table 1)

- compare analytical results from well points and adjacent near-surface water sampling (i.e. buckets) locations

\section{Methods}

The Environmental Sciences Section (ESS) of the Savannah River Technology Center (SRTC) conducted the third round of well point volatile organic compounds $(\mathrm{VOC})$ and tritium sampling in the wetlands at the old F-Area effluent ditch on August 25, 1994. Analytical services for the well point and bucket samples were obtained through a task order under Contract AA01244N with Weston Analytics (WA). WA analyzed the samples for compounds on the Appendix IX Volatiles list. All samples were submitted to the Environmental Monitoring Section (EMS) for tritium analysis. The SRTC's Analytical Development Section (ADS) analyzed two split samples for the volatile organics listed on the Target Compound List. A tentatively identified compounds (TIC) scan was also performed on each sample analyzed by ADS. Samples analyzed by ADS were considered quality assurance samples and were not used in the analyses and interpretations. A list of the constituents analyzed by each laboratory, along with the methods used and method detection limits, is given in Tables 2 and 3.

\section{Sampling Locations}

Samples were collected from seven locations in the wetlands along the old F-Area effluent ditch (Table 4 and Figure 1). Based on data from previous studies, locations exhibiting high tritium and volatile organic compound (VOC) concentrations were selected. Well point water samples were collected at all locations and bucket samples were collected at four locations. Bucket samples and well point samples share the same identification numbers, except the identification numbers for the bucket samples are suffixed with a "B". Background well point and bucket water samples were collected at two locations in wetlands along Upper Three Runs (UTR).

A blind duplicate sample was collected at location FHB014 and submitted to WA and EMS as a quality assurance/quality control (QA/QC) sample. Split samples were collected at locations FHB013 and FHB018 and submitted to ADS. One trip blank sample, QA2, was carried throughout all sampling activities. The trip blank consisted of two $40 \mathrm{ml}$ vials of deionized water. The trip blank was carried to each sampling location, handled like the collected samples, and submitted to WA for analyses. A field blank, QA3, was collected for VOCs at location FHB018. At this location, the caps were removed from two $40 \mathrm{ml}$ vials which were filled with deionized water and the samples were exposed to the atmosphere during collection activities. A blind duplicate sample for tritium was also collected at FHB018 and labeled QA3. The VOC field blank was submitted to WA for analyses and the tritium blind duplicate was submitted to EMS for analysis.

\section{Well Point Sample Collection}

Well points were installed according to WSRC-3Q5 (Chapter 7) procedures at each sampling location in February 1994. The well points were constructed of a 2-inch diameter PVC TriLok\& material to depths ranging from approximately 6 to $8 \mathrm{ft}$ below ground level. Each well point was screened over the bottom $2.5 \mathrm{ft}$ with TriLok® well screen $(0.010$ inch slot size). Figure 2 illustrates a schematic diagram of the well points. Boreholes were hand augured to depths ranging from approximately 6 to $8 \mathrm{ft}$ or until unconsolidated material was reached. The well points were then inserted into the boreholes and driven to the final depth. After the well points were inserted into the boreholes, a plastic lid with a 2-inch diameter hole was slipped onto the casing to a depth of 6 to 8 inches below the soil surface. To create a surface seal, bentonite was placed on top of the lid and the bentonite was covered with soil from the surrounding area. No grout or filter pack material was used in the construction of the well points.

One-inch diameter, 12 VDC submersible pumps were installed in each well and connected to the well cap using stainless steel tubing and swagelok connections. Each well cap was fitted with connections to facilitate measuring water levels and making headspace measurements. 
Well point samples were collected according to procedure ESSOP 2-115 (WSRC-L-14.1, 1993a). A brief description of the sampling procedure is described in this report; however, for a detailed discussion of the sampling procedure, ESSOP 2-115 should be reviewed.

Before collecting the well point samples, water level measurements were taken to determine the volume of water contained within the well point. Once the volume of water in each well point was determined, pumping was started and the flowrate was determined. Attempts were made at each well point to purge two well volumes; however, several of the well points pumped dried before purging two well volumes. In those cases, sample collection began when the well points recovered.

Conductivity and $\mathrm{pH}$ measurements were taken initially at the start of purging, and subsequently thereafter, for at least three sets of measurements until successive readings differed by less than ten percent. When three sets of successive measurements were within ten percent, stabilization requirements had been met and sample collection began. In cases where well points pumped dry, initial conductivity and $\mathrm{pH}$ measurements were taken and sample collection began when the well point recovered. All samples were obtained by collecting discharge directly from the pump. All containers were filled to the shoulder except VOC samples, which were completely filled such that no headspace remained. Total activity samples for shipping clearance were collected at each well point except at the background locations.

\section{Near-Surface Water Sample Collection}

Near-surface water samples (bucket samples) were collected according to procedure ESSOP 2-104 (WSRC-L-14.1, 1993d). A brief description of the sampling procedure is given described in this report; however, for a detailed discussion of the sampling procedure, ESSOP 2-104 should be reviewed.

Near-surface water sampling locations were already established as part of a previous project. At each location, a hole was excavated (approximately 18 inches deep) using a decontaminated stainless steel shovel. A five-gallon plastic bucket screened on the sides and bottom was placed in the hole and covered with a lid. All buckets were bailed the day before sample collection began to ensure that a representative sample of the local shallow groundwater was being collected. Conductivity and $\mathrm{pH}$ measurements were taken at each bucket sampling location. All samples were collected by dipping the containers directly into the water in the bucket. VOC samples were completely filled such that no headspace remained. Other sample containers were filled to the shoulder.

\section{Sample Processing}

When the sample containers for a location were filled, they were stored in a cooler containing blue ice for transport to the processing area. At the processing area, the samples were stored at $4^{\circ} \mathrm{C}$ until they were packaged for shipment. Samples were packed and shipped according "Packaging Nonradioactive Water Samples for Offsite Shipment" and "Packaging Radioactive Water Samples for Offsite Shipment" (WSRC-3Q5, Ch.15) procedures. The particular procedure used was determined by the total activity results. Chain of custody procedures were followed for all samples.

\section{Data Validation}

Weston Analytics (WA) submitted hard copies and electronic data diskettes (EDD) containing the analytical data to ESS. The hard copies were considered the laboratory-validated data packages and consisted of a case narrative for each batch, the result of the analyses, and QAVQC information (i.e., spike recoveries). The EDDs consisted of one flat ASCII computer file for each laboratory batch. The data were formatted on the EDDs into the AN92 data format to provide the information in Appendix B. ADS and EMS submitted hard copies of the analytical data, which were manually entered into a spreadsheet and verified by ESS. Each EDD file was uploaded onto an IBM mainframe computer at SRS. The files were then merged to create one file to accommodate data review and validation activities.

The names of the blind replicate samples were changed to the correct location number and marked as a replicate sample. Statistical Application Software (SAS) computer programs were run on each file to verify the data. The following data verification checks were made using the SAS programs:

- verifying the location names and sample dates

- $\quad$ identifying data entry errors (incorrect methods or units)

- $\quad$ verifying that samples were analyzed within hold times

- verifying that all result and analysis qualifiers were valid. 
Any suspected data entry errors were documented and submitted to WA for verification or correction. Changes to the database were recorded in a logbook.

After all data entry errors were resolved, the data were downloaded into an Excel spreadsheet, where they were screened to identify missing analyses and duplicate records. The laboratory was notified of any data that were missing and responded by submitting an EDD for the analysis. Duplicate records were deleted from the database after the laboratory determined they had, in error, submitted the data twice.

The results from samples that were used as laboratory replicates were averaged when both analyses were above the detection limit. Data below the detection limit and data presented with result or analysis qualifiers were not averaged and are noted in the comprehensive data tables (Appendix A) by "NA" in the "Averaged" column. Data that were averaged are noted with an " $\mathrm{A}$ " in the "Averaged" column.

Other data validation checks included:

- verifying that all surrogates and spikes were within acceptable recovery ranges

- determining lab blanks with results above detection limits and verifying that these results were qualified accordingly. 
Table 1. Primary Drinking Water Standards and Maximum Contaminant Levels Used in Data Comparisons.

\begin{tabular}{|c|c|c|c|}
\hline Analyte & Standard & Units & Source \\
\hline 1,1,1,2-Tetrachloroethane & $\mathrm{NS}^{1}$ & & \\
\hline 1,1,1-Trichloroethane & 200 & $\mu g / L$ & EPA, 1993a \\
\hline 1,1,2,2-Tetrachloroethane & NS & & \\
\hline 1,1,2-Trichloroethane & 5 & $\mu g / L$ & EPA, 1993b \\
\hline 1,1-Dichloroethane & NS & & \\
\hline 1,1-Dichloroethylene & 7 & $\mu \mathrm{g} / \mathrm{L}$ & EPA, 1993a \\
\hline 1,2,3-Trichloropropane & NS & & \\
\hline 1,2-Dibromo-3-chloropropane & 0.2 & $\mu g / L$ & EPA, 1993a \\
\hline 1,2-Dibromoethane & NS & & \\
\hline 1,2-Dichloroethane & 5 & $\mu \mathrm{g} / \mathrm{L}$ & EPA, 1993a \\
\hline 1,2-Dichloroethylene (total) & $70^{2}$ & $\mu \mathrm{g} / \mathrm{L}$ & EPA, 1993a \\
\hline 1,2-Dichloropropane & 5 & $\mu \mathrm{g} / \mathrm{L}$ & EPA, 1993a \\
\hline 2-Hexanone & NS & & \\
\hline 4-Methyl-2-pentanone & NS & & \\
\hline Acetone & NS & & \\
\hline Acetonitrile (Methyl cyanide) & NS & & \\
\hline Acrolein & NS & & \\
\hline Acrylonitrile & NS & & \\
\hline Allyl chloride & NS & & \\
\hline Benzene & 5 & $\mu \mathrm{g} / \mathrm{L}$ & EPA, 1993a \\
\hline Bromodichloromethane & NS & & \\
\hline Bromoform & NS & & \\
\hline Carbon disulfide & NS & & \\
\hline Carbon tetrachloride & 5 & $\mu \mathrm{g} / \mathrm{L}$ & EPA, 1993a \\
\hline Chlorobenzene & 100 & $\mu \mathrm{g} / \mathrm{L}$ & EPA, 1993a \\
\hline Chloroethane & NS & & \\
\hline Chloroform & 100 & $\mu g / L$ & $\mathrm{EPA}, 1991 \mathrm{a}$ \\
\hline Chloroprene & NS & & \\
\hline cis-1,2-Dichloroethylene & 70 & $\mu \mathrm{g} / \mathrm{L}$ & EPA, 1993a \\
\hline cis-1,3-Dichloropropene & NS & & \\
\hline Dibromochloromethane & NS & & \\
\hline Dichlorodifluoromethane & NS & & \\
\hline Ethyl methacrylate & NS & & \\
\hline Ethylbenzene & 700 & $\mu \mathrm{g} / \mathrm{L}$ & EPA, 1993a \\
\hline Isobutyl alcohol & NS & & \\
\hline Methacrylonitrile & NS & & \\
\hline Methyl bromide & NS & & \\
\hline Methyl chloride & NS & & \\
\hline Methyl ethyl ketone & NS & & \\
\hline Methyl iodide & NS & & \\
\hline Methyl methacrylate & NS & & \\
\hline Methylene bromide & NS & & \\
\hline Methylene chloride & 5 & $\mu \mathrm{g} / \mathrm{L}$ & EPA, 1993b \\
\hline Pentachloroethane & NS & & \\
\hline Propionitrile & NS & & \\
\hline Styrene & 100 & $\mu \mathrm{g} / \mathrm{L}$ & EPA, 1993a \\
\hline Tetrachloroethylene & 5 & $\mu \mathrm{g} / \mathrm{L}$ & EPA, 1993a \\
\hline Toluene & 1000 & $\mu \mathrm{g} / \mathrm{L}$ & EPA, 1993a \\
\hline
\end{tabular}

1 No standard

${ }^{2} \mathrm{MCL}$ listed is for cis-1,2-dichloroethylene. 
Table 1. Primary Drinking Water Standards and Maximum Contaminant Levels Used in Data Comparisons. (Cont.)

\begin{tabular}{lccc} 
Analyte & Standard & Units & Source \\
\hline trans-1,2-Dichloroethylene & 100 & $\mu \mathrm{g} / \mathrm{L}$ & EPA, 1993a \\
trans-1,3-Dichloropropene & $\mathrm{NS}$ & & \\
trans-1,4-Dichloro-2-butene & $\mathrm{NS}$ & & \\
Trichloroethylene & 5 & $\mu \mathrm{g} / \mathrm{L}$ & $\mathrm{EPA}, 1991 \mathrm{a}$ \\
Trichlorofluoromethane & $\mathrm{NS}$ & & \\
Trichlorofluoromethane & $\mathrm{NS}$ & & \\
Tritium & 20 & $\mathrm{pCi} / \mathrm{ml}$ & $\mathrm{EPA}, 1993 \mathrm{a}$ \\
Vinyl acetate & $\mathrm{NS}$ & & \\
Vinyl chloride & 2 & $\mu \mathrm{g} / \mathrm{L}$ & EPA, 1993a \\
Xylenes (total) & 10000 & $\mu \mathrm{g} / \mathrm{L}$ & EPA, 1993a \\
\hline
\end{tabular}

1No standard 
Table 2. Methods and Method Detection Limits for Weston Analytics and Environmental Monitoring Section.

\begin{tabular}{|c|c|c|c|c|}
\hline Analyte & Lab & Method & MDL 1 & Units \\
\hline 1,1,1,2-Tetrachloroethane & $\overline{W A}$ & EPA8240 & 10 & $\mu \mathrm{g} / \mathrm{L}$ \\
\hline 1,1,1-Trichloroethane & WA & EPA 8240 & 5 & $\mu \mathrm{g} / \mathrm{L}$ \\
\hline 1,1,2,2-Tetrachloroethane & WA & EPA 8240 & 5 & $\mu \mathrm{g} / \mathrm{L}$ \\
\hline 1,1,2-Trichloroethane & WA & EPA8240 & 5 & $\mu \mathrm{g} / \mathrm{L}$ \\
\hline 1,1-Dichloroethane & WA & EPA 8240 & 5 & $\mu \mathrm{g} / \mathrm{L}$ \\
\hline 1,1-Dichloroethylene & WA & EPA8240 & 5 & $\mu \mathrm{g} / \mathrm{L}$ \\
\hline 1,2,3-Trichloropropane & WA & EPA 8240 & 10 & $\mu \mathrm{g} / \mathrm{L}$ \\
\hline 1,2-Dibromo-3-chloropropane & WA & EPA8240 & 20 & $\mu \mathrm{g} / \mathrm{L}$ \\
\hline 1,2-Dibromoethane & WA & EPA8240 & 20 & $\mu \mathrm{g} / \mathrm{L}$ \\
\hline 1,2-Dichloroethane & WA & EPA8240 & 5 & $\mu \mathrm{g} / \mathrm{L}$ \\
\hline 1,2-Dichloroethylene (total) & WA & EPA8240 & 5 & $\mu \mathrm{g} / \mathrm{L}$ \\
\hline 1,2-Dichloropropane & WA & EPA8240 & 5 & $\mu \mathrm{g} / \mathrm{L}$ \\
\hline 2-Hexanone & WA & EPA8240 & 10 & $\mu \mathrm{g} / \mathrm{L}$ \\
\hline 4-Methyl-2-pentanone & WA & EPA 8240 & 10 & $\mu \mathrm{g} / \mathrm{L}$ \\
\hline Acetone & WA & EPA 8240 & 10 & $\mu \mathrm{g} / \mathrm{L}$ \\
\hline Acetonitrile (Methyl cyanide) & WA & EPA 8240 & 20 & $\mu \mathrm{g} / \mathrm{L}$ \\
\hline Acrolein & WA & EPA 8240 & 10 & $\mu \mathrm{g} / \mathrm{L}$ \\
\hline Acrylonitrile & WA & EPA8240 & 10 & $\mu \mathrm{g} / \mathrm{L}$ \\
\hline Allyl chloride & WA & EPA8240 & 100 & $\mu \mathrm{g} / \mathrm{L}$ \\
\hline Benzene & WA & EPA8240 & 5 & $\mu \mathrm{g} / \mathrm{L}$ \\
\hline Bromodichloromethane & WA & EPA8240 & 5 & $\mu \mathrm{g} / \mathrm{L}$ \\
\hline Bromoform & WA & EPA 8240 & 5 & $\mu \mathrm{g} / \mathrm{L}$ \\
\hline Carbon disulfide & WA & EPA 8240 & 5 & $\mu \mathrm{g} / \mathrm{L}$ \\
\hline Carbon tetrachloride & WA & EPA8240 & 5 & $\mu \mathrm{g} / \mathrm{L}$ \\
\hline Chlorobenzene & WA & EPA8240 & 5 & $\mu \mathrm{g} / \mathrm{L}$ \\
\hline Chloroethane & WA & EPA8240 & 10 & $\mu \mathrm{g} / \mathrm{L}$ \\
\hline Chloroform & WA & EPA8240 & 5 & $\mu \mathrm{g} / \mathrm{L}$ \\
\hline Chloroprene & WA & EPA8240 & 20 & $\mu \mathrm{g} / \mathrm{L}$ \\
\hline cis-1,3-Dichloropropene & WA & EPA8240 & 5 & $\mu \mathrm{g} / \mathrm{L}$ \\
\hline Dibromochloromethane & WA & EPA8240 & 5 & $\mu \mathrm{g} / \mathrm{L}$ \\
\hline Dichlorodifluoromethane & WA & EPA8240 & 10 & $\mu \mathrm{g} / \mathrm{L}$ \\
\hline Ethylbenzene & WA & EPA8240 & 5 & $\mu \mathrm{g} / \mathrm{L}$ \\
\hline Isobutyl alcohol & WA & EPA8240 & 20 & $\mu \mathrm{g} / \mathrm{L}$ \\
\hline Methacrylonitrile & WA & EPA8240 & 20 & $\mu \mathrm{g} / \mathrm{L}$ \\
\hline Methyl bromide & WA & EPA8240 & 10 & $\mu \mathrm{g} / \mathrm{L}$ \\
\hline Methyl chloride & WA & EPA8240 & 10 & $\mu \mathrm{g} / \mathrm{L}$ \\
\hline Methyl ethyl ketone & WA & EPA8240 & 10 & $\mu \mathrm{g} / \mathrm{L}$ \\
\hline Methyl iodide & WA & EPA8240 & 10 & $\mu \mathrm{g} / \mathrm{L}$ \\
\hline Methylene bromide & WA & EPA8240 & 10 & $\mu \mathrm{g} / \mathrm{L}$ \\
\hline Methylene chloride & WA & EPA 8240 & 5 & $\mu \mathrm{g} / \mathrm{L}$ \\
\hline Propionitrile & WA & EPA8240 & 50 & $\mu \mathrm{g} / \mathrm{L}$ \\
\hline Styrene & WA & EPA8240 & 5 & $\mu \mathrm{g} / \mathrm{L}$ \\
\hline Tetrachloroethylene & WA & EPA8240 & 5 & $\mu \mathrm{g} / \mathrm{L}$ \\
\hline Toluene & WA & EPA8240 & 5 & $\mu \mathrm{g} / \mathrm{L}$ \\
\hline trans-1,3-Dichloropropene & WA & EPA8240 & 5 & $\mu \mathrm{g} / \mathrm{L}$ \\
\hline trans-1,4-Dichloro-2-butene & WA & EPA8240 & 100 & $\mu \mathrm{g} / \mathrm{L}$ \\
\hline
\end{tabular}

${ }_{1}$ MDL - Method Detection Limit 
Table 2. Methods and Method Detection Limits for Weston Analytics and Environmental Monitoring Section. (cont'd)

\begin{tabular}{lllcc} 
Analyte & Lab & Method & MDL 1 & Units \\
\hline Trichloroethylene & WA & EPA8240 & 5 & $\mu \mathrm{g} / \mathrm{L}$ \\
Trichlorofluoromethane & WA & EPA8240 & 5 & $\mu \mathrm{g} / \mathrm{L}$ \\
Tritium & EMS & EMS2760 & 1 & $\mathrm{pCi} / \mathrm{ml}$ \\
Vinyl acetate & WA & EPA8240 & 10 & $\mu \mathrm{g} / \mathrm{L}$ \\
Vinyl chloride & WA & EPA8240 & 10 & $\mu \mathrm{g} / \mathrm{L}$ \\
Xylenes (total) & WA & EPA8240 & 5 & $\mu \mathrm{g} / \mathrm{L}$ \\
\hline
\end{tabular}

${ }_{1} \mathrm{MDL}$ - Method Detection Limit 
Table 3. Methods and Practical Quantitation Limits for Analytical Development Section.

\begin{tabular}{|c|c|c|c|c|}
\hline Analyte & Lab & Method & PQL ${ }^{1}$ & Units \\
\hline 1,1,1-Trichloroethane & $\overline{\mathrm{ADS}}$ & ADS2656 & 50 & $\mu \mathrm{g} / \mathrm{L}$ \\
\hline 1,1,2,2-Tetrachloroethane & ADS & ADS2656 & 50 & $\mu \mathrm{g} / \mathrm{L}$ \\
\hline 1,1,2-Trichloroethane & ADS & ADS2656 & 50 & $\mu \mathrm{g} / \mathrm{L}$ \\
\hline 1,1-Dichloroethane & ADS & ADS2656 & 50 & $\mu \mathrm{g} / \mathrm{L}$ \\
\hline 1,1-Dichloroethylene & ADS & ADS2656 & 50 & $\mu \mathrm{g} / \mathrm{L}$ \\
\hline 1,2-Dichloroethane & ADS & ADS2656 & 50 & $\mu \mathrm{g} / \mathrm{L}$ \\
\hline 1,2-Dichloropropane & ADS & ADS2656 & 50 & $\mu \mathrm{g} / \mathrm{L}$ \\
\hline 2-Hexanone & ADS & ADS2656 & 50 & $\mu \mathrm{g} / \mathrm{L}$ \\
\hline 4-Methyl-2-pentanone & ADS & ADS2656 & 50 & $\mu \mathrm{g} / \mathrm{L}$ \\
\hline Acetone & ADS & ADS2656 & 50 & $\mu \mathrm{g} / \mathrm{L}$ \\
\hline Benzene & ADS & ADS2656 & 50 & $\mu \mathrm{g} / \mathrm{L}$ \\
\hline Bromodichloromethane & ADS & ADS2656 & 50 & $\mu \mathrm{g} / \mathrm{L}$ \\
\hline Bromoform & ADS & ADS2656 & 50 & $\mu \mathrm{g} / \mathrm{L}$ \\
\hline Carbon disulfide & ADS & ADS2656 & 50 & $\mu \mathrm{g} / \mathrm{L}$ \\
\hline Carbon tetrachloride & ADS & ADS2656 & 50 & $\mu \mathrm{g} / \mathrm{L}$ \\
\hline Chlorobenzene & ADS & ADS2656 & 50 & $\mu \mathrm{g} / \mathrm{L}$ \\
\hline Chloroethane & ADS & ADS2656 & 50 & $\mu \mathrm{g} / \mathrm{L}$ \\
\hline Chloroform & ADS & ADS2656 & 50 & $\mu \mathrm{g} / \mathrm{L}$ \\
\hline cis-1,2-Dichloroethylene & ADS & ADS2656 & 50 & $\mu \mathrm{g} / \mathrm{L}$ \\
\hline cis-1,3-Dichloropropene & ADS & ADS2656 & 50 & $\mu \mathrm{g} / \mathrm{L}$ \\
\hline Dibromochloromethane & $\mathrm{ADS}$ & ADS2656 & 50 & $\mu \mathrm{g} / \mathrm{L}$ \\
\hline Ethylbenzene & ADS & ADS2656 & 50 & $\mu \mathrm{g} / \mathrm{L}$ \\
\hline Methyl ethyl ketone & ADS & ADS2656 & 50 & $\mu \mathrm{g} / \mathrm{L}$ \\
\hline Methylene chloride & ADS & ADS2656 & 50 & $\mu \mathrm{g} / \mathrm{L}$ \\
\hline Styrene & ADS & ADS2656 & 50 & $\mu \mathrm{g} / \mathrm{L}$ \\
\hline Tetrachloroethylene & ADS & ADS2656 & 50 & $\mu \mathrm{g} / \mathrm{L}$ \\
\hline Toluene & ADS & ADS2656 & 50 & $\mu \mathrm{g} / \mathrm{L}$ \\
\hline trans-1,2-Dichloroethylene & ADS & ADS2656 & 50 & $\mu \mathrm{g} / \mathrm{L}$ \\
\hline trans-1,3-Dichloropropene & ADS & ADS2656 & 50 & $\mu \mathrm{g} / \mathrm{L}$ \\
\hline Trichloroethylene & ADS & ADS2656 & 50 & $\mu \mathrm{g} / \mathrm{L}$ \\
\hline Vinyl Acetate & ADS & ADS2656 & 50 & $\mu \mathrm{g} / \mathrm{L}$ \\
\hline Vinyl chloride & ADS & ADS2656 & 50 & $\mu \mathrm{g} / \mathrm{L}$ \\
\hline Xylenes (total) & ADS & ADS2656 & 50 & $\mu \mathrm{g} / \mathrm{L}$ \\
\hline
\end{tabular}

${ }^{1}$ Practical Quantitation Limit. The PQL is sample specific and is dependent upon the number of dilutions made to the sample. The $\mathrm{PQL}$ for all samples was $50 \mu \mathrm{g} /$, based on a five-fold dilution of the samples. 
Table 4. Well Point and Near-Surface Water (bucket) Sampling Locations.

\begin{tabular}{lccc} 
Sampling Location & $\begin{array}{r}\text { SRS } \\
\text { North }\end{array}$ & $\begin{array}{c}\text { Coordinates } \\
\text { East }\end{array}$ & $\begin{array}{c}\text { Elevation } \\
\text { (msI) }\end{array}$ \\
\hline FHB013 & 73514 & 53840 & 211.2 \\
FHB013B $^{2}$ & 73514 & 53840 & 211.2 \\
FHB014 & 73571 & 53729 & 212.0 \\
FHB014B & 73571 & 53729 & 212.0 \\
FHB016 & 73718 & 54032 & 217.4 \\
FHB017 & 73672 & 53990 & 217.5 \\
FHB018 & 73567 & 54024 & 214.4 \\
FHB018B & 73567 & 54024 & 214.4 \\
FHB019 & 73489 & 53896 & 211.6 \\
FHB020 & 73431 & 54011 & 212.4 \\
FHB020B & 73431 & 54011 & 212.4 \\
BGS002 & 93839 & 87018 & 177.7 \\
BGS002B & 93839 & 87018 & 177.7 \\
BGS003 & 94252 & 81794 & 178.6 \\
BGS003B & 94252 & 81794 & 178.6 \\
\hline
\end{tabular}

$1_{\text {Ground elevation above mean sea level. }}$

${ }^{2}$ Location identification numbers ending with the suffix " $\mathrm{B}$ " designate nearsurface water, or bucket, sampling locations. 


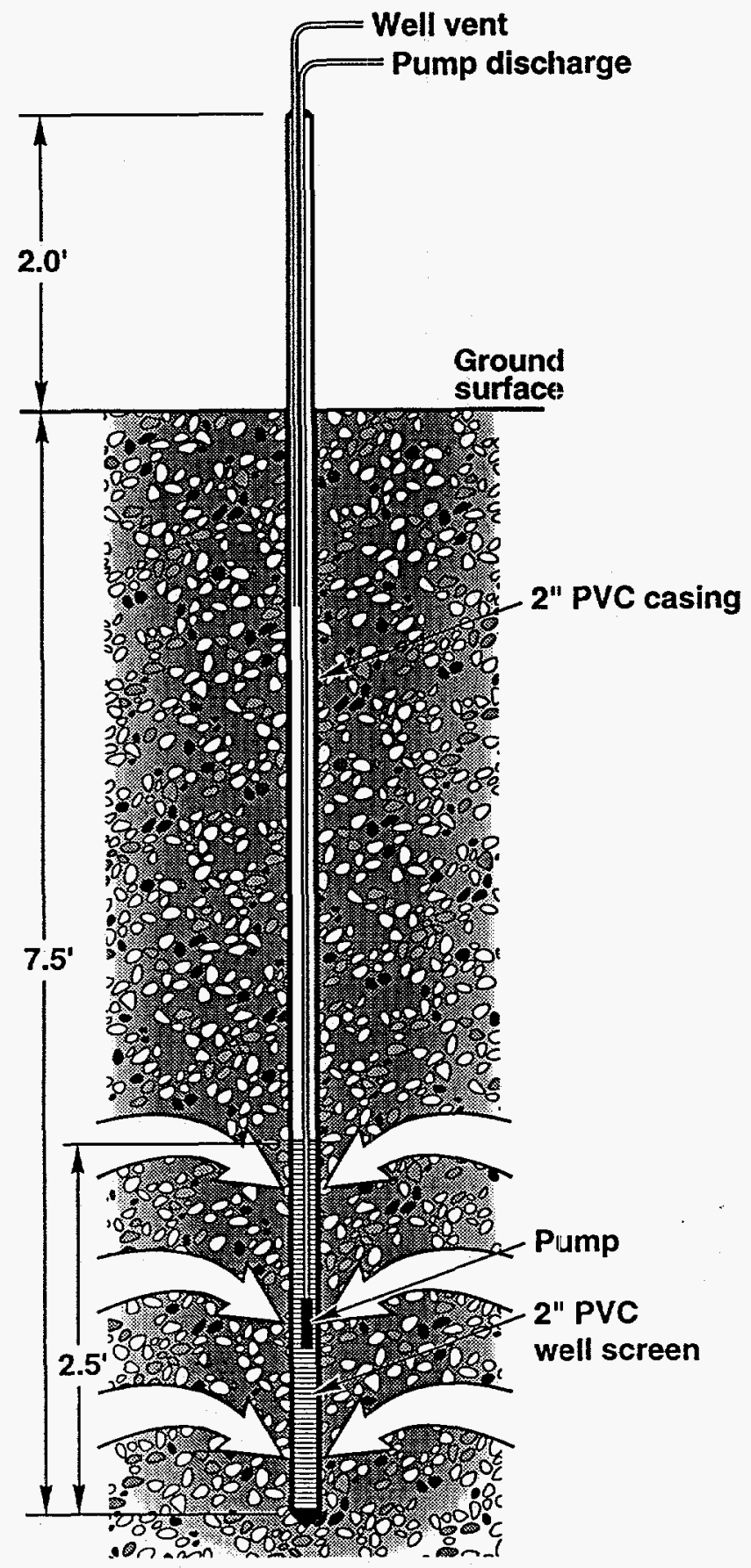

Figure 2. Schematic Diagram of Well Points. 


\section{Discussion}

Analytical services were provided by three laboratories. Weston Analytics (WA) was used as the reference laboratory for volatile organic compound (VOC) analyses and the Environmental Protection Department's (EPD) Environmental Monitoring Section (EMS) was used as the reference laboratory for the tritium analyses. SRTC's Analytical Development Section (ADS) analyzed split samples. The samples analyzed by WA and EMS were considered the reference samples on which all analyses and interpretations were based. Well point samples analyzed by ADS were considered the quality assurance samples and were not used in the analyses and interpretations. These considerations should prevent inter-lab variability of constituent concentrations from biasing the analyses and interpretation.

Analytical results for the August 1994 sampling event in the wetlands along the old F-Area effluent ditch south of 643-E (old burial ground) are presented in Appendix A. Location identification numbers ending with the "B" suffix designate bucket water sampling locations. All other identification numbers, excluding quality assurance samples, are well point locations. The results are presented in a format similar to that used in the quarterly groundwater monitoring reports issued by EMS (EMS, 1993). For each sampling location, the sampling date, field measurements, including water level elevation (well points only), $\mathrm{pH}$, conductivity, etc., and all laboratory analyses, are presented (excluding lab blanks and standards). Included in the laboratory analysis tables for each location and analyte is the lab that performed the analyses, result or analytical modifiers, the analytical results, and standards (PDWS and MCL). The legend at the beginning of Appendix A explains the abbreviations and modifiers used to present the data. For locations where split samples were collected (well points FHB013 and FHB018), results from each lab are presented for each analyte. Laboratory duplicates were averaged with their corresponding reference samples, except in cases where the duplicate or reference analysis was reported at or below detection limit or in cases where results were qualified with a result or analysis qualifier.

In addition to the split samples, other standard quality assurance/quality control (QA/QC) samples were collected. These included a blind replicate sample collected at FHB014 (FHB014 R), a volatile trip blank shipped with the nonradioactive samples (FVA001), a trip blank sample carried throughout sampling activities (QA2), a field blank sample collected at FHB018 (QA3) for VOCs, and a blind duplicate sample (QA3) collected at FHB018 for tritium. All samples deemed nonradioactive, as defined by Department of Transportation (DOT) regulations, were shipped in the same shipping container on August 29, 1994. By the same definition, samples considered to be limited quantities of excepted radioactive material were shipped in the same shipping container on August 29, 1994. To minimize volume for the radioactive shipment, a volatile trip blank was not shipped with these samples.

\section{Field Measurements}

Conductivity and $\mathrm{pH}$ were measured at each well point and bucket location and the results are presented in Appendix A. Conductivity and $\mathrm{pH}$ results for well point and bucket locations are measurements taken as the samples were collected. Conductivity and $\mathrm{pH}$ measurements taken during well purging are given in the field data sheets. The $\mathrm{pH}$ of the well point and bucket locations ranged from 4.9 to 5.8 and 4.9 to 5.6, respectively. The average $\mathrm{pH}$ of the well point and bucket locations was 5.3 and 5.3 , respectively. The conductivity of the well point and bucket locations ranged from 29 to $55 \mu \mathrm{S} / \mathrm{cm}$ and 34 to $196 \mu \mathrm{S} / \mathrm{cm}$, respectively. The $\mathrm{pH}$ values measured for the well point and bucket locations are comparable to the $\mathrm{pH}$ measured at the background locations, while conductivity values suggest some locations are being influenced by elevated ion concentrations. Conductivity and $\mathrm{pH}$ measurements for well points and buckets are within the range commonly observed in the water table wells around 643-E.

\section{Comparison of Well and Bucket Sampling Locations to Established Standards}

Since most of the analytical data from the well point and bucket sampling locations in the wetlands along the old FArea effluent ditch were reported as below the method detection limit (MDL) and virtually all of the background data was reported as below the MDL, interpretation and analysis of the data are based completely on observed trends rather than statistical analyses. The small sample size and numerous data reported below the MDL make statistical analysis of the data impractical.

Four different analytes were detected at concentrations above the MDL for the well points (including background locations). These analytes were reported without any type of result or analysis qualifiers and represented eight percent of the analyses performed for each well point. Table 5 lists the detected analytes and the number of well points at which each analyte was detected. 
Figures 3, 4, and 5 show maps of the 1,2-dichloroethylene (total), trichloroethylene, and tritium plumes as measured in the well points at the old F-Area effluent ditch. For each figure, the symbol size for the analyte presented is linearly proportional to the concentration measured. These figures should give the reader a feel for the general location where each of these analytes were measured as well as the concentration of each analyte. The highest 1,2dichloroethylene (total) and tritium concentrations $(336 \mu \mathrm{g} / \mathrm{L}$ and $61,300 \mathrm{pCi} / \mathrm{ml}$, respectively) were measured at well point FHB018, whereas the highest tetrachloroethylene and trichloroethylene concentrations (16.1 and $34.8 \mu \mathrm{g} / \mathrm{L}$, respectively) were measured at well point FHB019.

A list of analytes, along with the corresponding well point locations where concentrations were at levels greater than those established by the PDWS (EPA, 1991) or the MCL (EPA, 1993a and b), is given in Table 6. Four analytes, 1,2-dichloroethylene (total), tetrachloroethylene, trichloroethylene, and tritium, were found to be above these standards at one or more well point locations.

Five different analytes were detected at concentrations above MDL for the bucket locations (including background locations). These analytes-1,2-dichloroethylene, tetrachloroethlyene, trichloroethylene, tritium, and vinyl chloride - were reported without result or analysis qualifiers and represented approximately 15 percent of the analyses performed for each bucket location. Table 7 lists the detected analytes and the number of buckets at which each analyte was detected.

A list of analytes, along with the corresponding bucket sampling locations where concentrations were at levels greater than those established by the PDWS (EPA, 1991) or the MCL (EPA, 1993a and b), is given in Table 8. Four analytes-1,2-dichloroethylene (total), trichloroethylene, tritium and. vinyl chloride-were above these standards at one or more bucket locations.

\section{Comparison of Well and Bucket Sampling Locations}

As mentioned earlier, a secondary objective of this project: is to compare analytical results from the well and bucket sampling methodologies to determine differences. For the August sampling event, the VOCs common to both well point and bucket samples were 1,2-dichloroethylene (total), trichloroethylene, and tetrachloroethylene. Vinyl chloride was detected at least once in the buckets but not in the well points

Local flow lines in areas of shallow groundwater discharge can be complex. Therefore, it would not be uncommon for sampling locations in close proximity to intercept different flow lines and yield water with different chemical characteristics, as illustrated in Figure 6. For this project, well points and buckets were within a few feet of each other, but installed at different depths. Figure 6 shows a schematic diagram of the water table flow lines near 643-E. This figure clearly shows that well points and buckets (or near-surface samplers) installed at different depths can intercept different groundwater flow paths and plume concentration zones. Since plume concentrations can vary substantially across different flow lines, direct comparison of the results obtained from the two sampling devices would be inappropriate.

Volatilization losses of tritium should be negligible and if the sampling devices intercept the same flow lines, tritium results between the well points and buckets should be comparable. Percent differences between tritium concentrations measured in the well points and those measured in the buckets are shown in Table 9. Observed differences are substantial for those locations where significant concentrations were measured. These differences suggest that the well points and buckets do intercept different flow lines. As a result, differences would be expected and were observed between VOC concentrations measured in the well points and those measured in the buckets.

For the August 1994 sampling event, VOC concentrations measured at each well point and bucket location were normalized based on the percent differences observed in tritium concentrations at that location. Resulting well point and bucket VOC concentrations were comparable in most cases. These results suggested that volatilization losses of organic compounds from the buckets may be negligible. For direct comparison of results in the future, it will be necessary to install well points and buckets to about the same depth to ensure that the devices intercept the same groundwater flow paths. 


\section{1,2-Dichloroethylene Plume at Old F-Area Effluent Ditch}

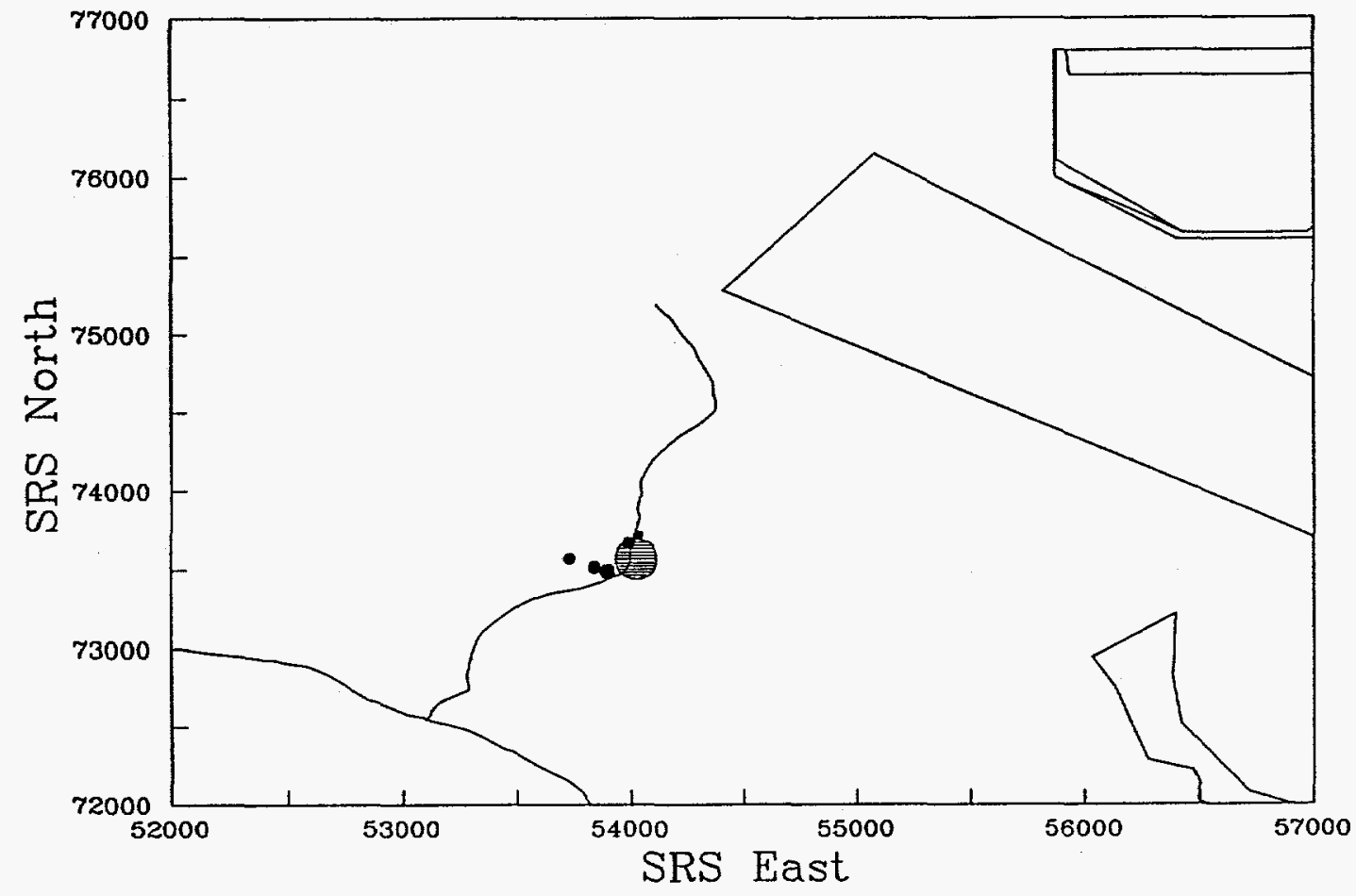

Figure 3. 1,2-Dichloroethylene (total) Plume at the Old F-Area Effluent Ditch.

Note: The symbol size for the analyte presented is linearly proportional to the concentration measuired. This figure should give the reader a general feel for the general location where the analyte was detected and the concentration of the analyte. 


\section{Trichloroethylene Plume at Old F-Area Effluent Ditch}

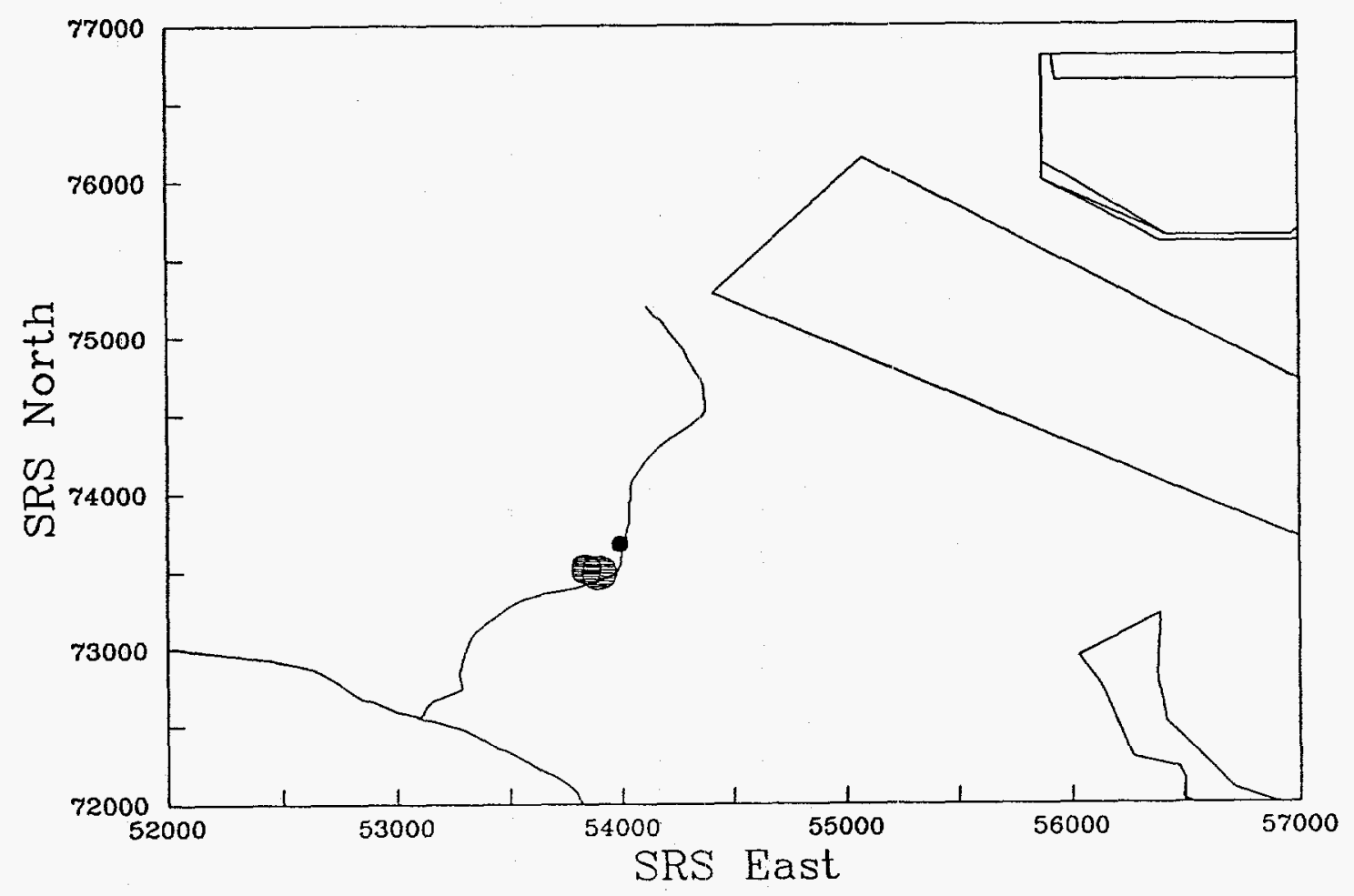

Figure 4. Trichloroethylene Plume at the Old F-Area Effluent Ditch.

Note: The symbol size for the analyte presented is linearly proportional to the concentration measured. This figure should give the reader a general feel for the general location where the analyte was detected and the concentration of the analyte. 


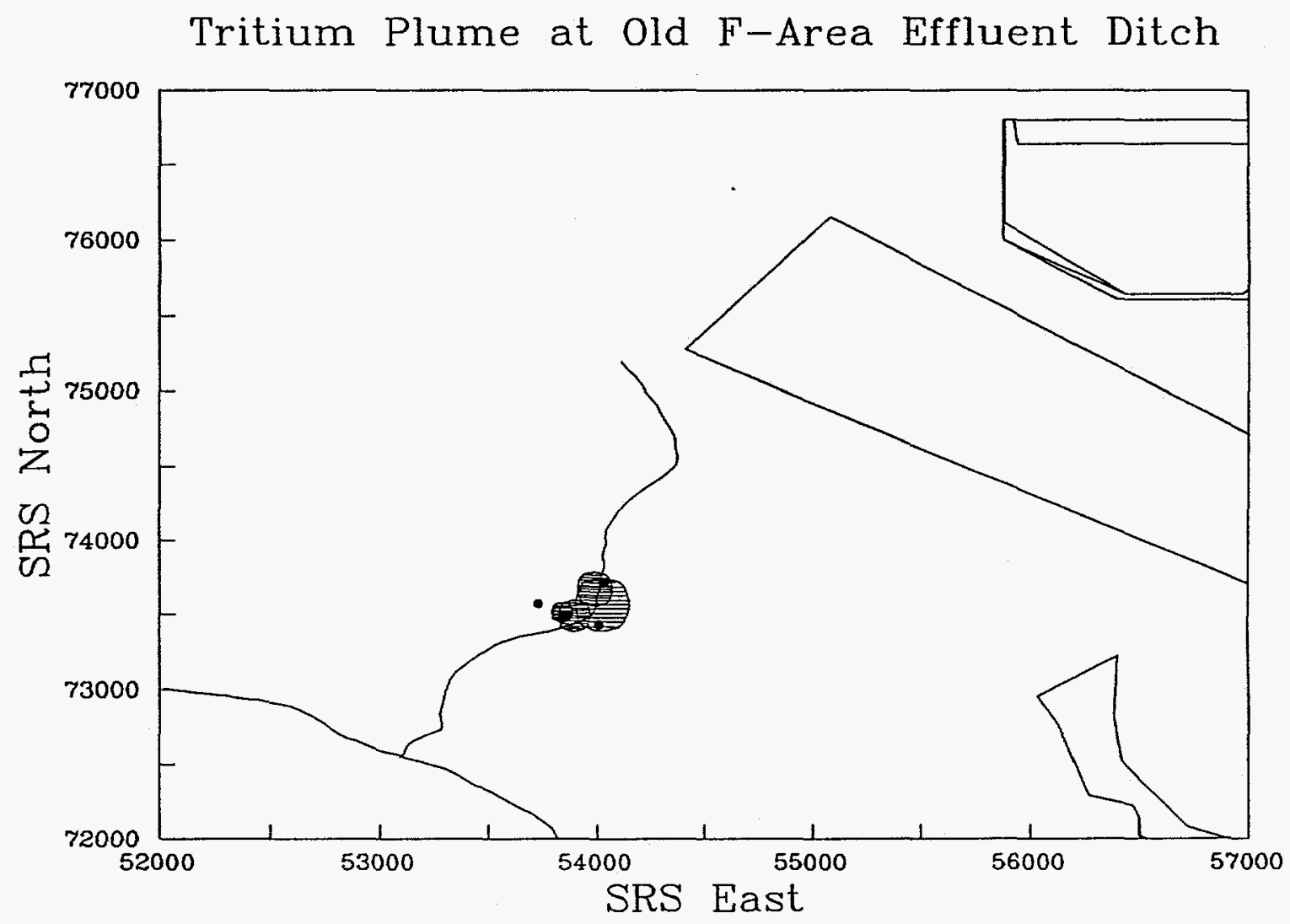

Figure 5. Tritium Plume at the Old F A Area Effluent Ditch.

Note: The symbol size for the analyte presented is linearly proportional to the concentration measured. This figure should give the reader a general feel for the general location where the analyte was detected and the concentration of the analyte. 


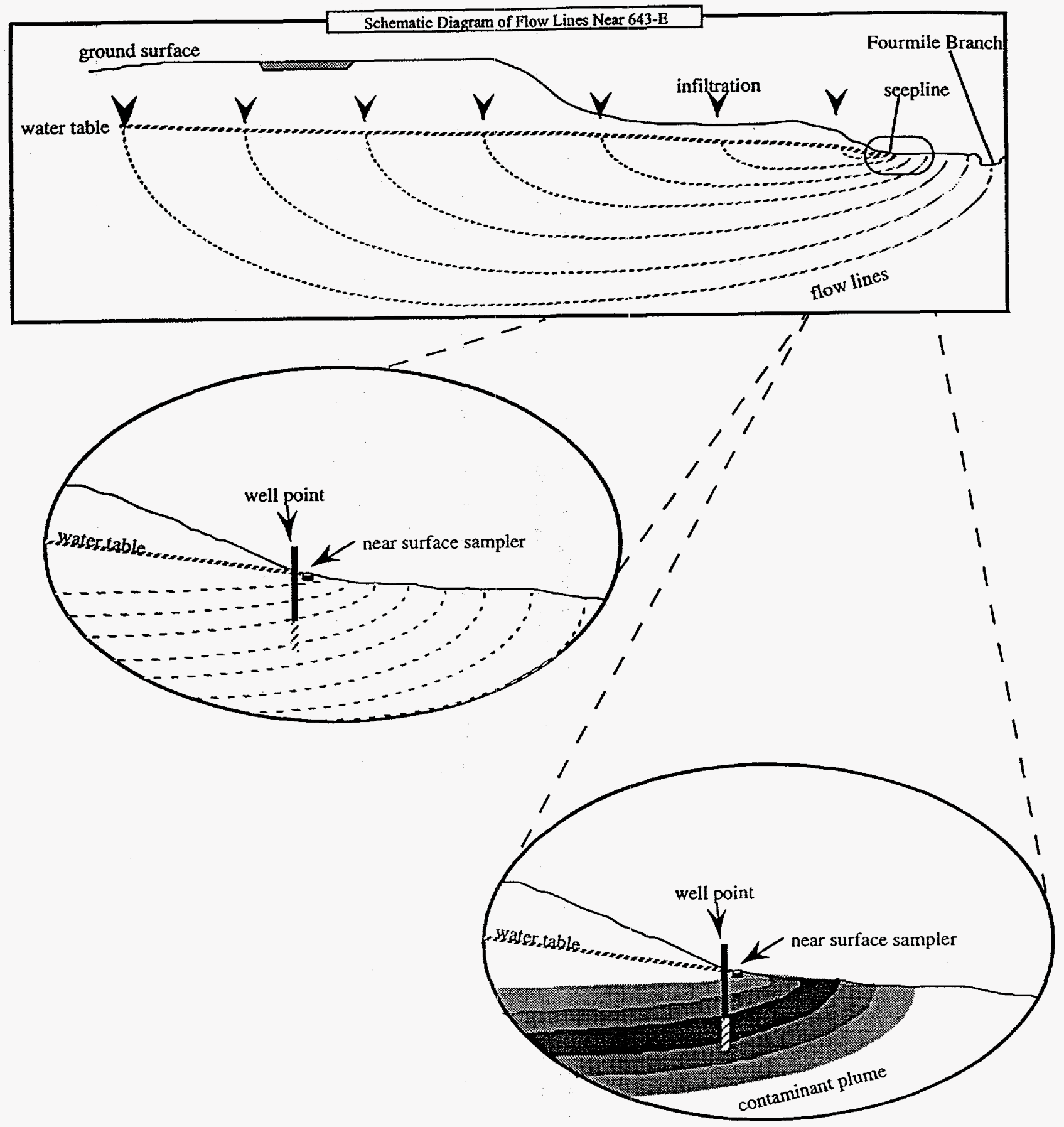

Figure 6. Schematic Diagram of Flow Lines Near 643-E with the Seepline Intercept Enlarged to Show How Well Points and Near-Surface Water Samplers (buckets) Intercept Different Flow Lines and Plume Concentrations Zones. 
Table 5. Analytes Detected at Well Point Locations.

\begin{tabular}{lcc} 
Analyte & $\begin{array}{c}\text { Number of } \\
\text { Well Points }\end{array}$ & $\begin{array}{c}\text { Number of } \\
\text { Detects }\end{array}$ \\
\hline 1,2-Dichloroethylene (total) & 9 & 6 \\
Tetrachloroethylene & 9 & 2 \\
Trichloroethylene & 9 & 3 \\
Tritium & 9 & 9 \\
\hline
\end{tabular}

Table 6. Analytes and Corresponding Well Point Locations Where August 1994 Concentrations Exceeded the Primary Drinking Water Standards or Maximum Contaminant Levels.

\begin{tabular}{lcccccc} 
Analyte & Lab & Result & Accuracy & Standard & Units & Location \\
\hline 1,2-Dichloroethylene (total) & WA & 336 & & 70 & $\mathrm{mg} / \mathrm{L}$ & FHB018 \\
Tetrachloroethylene & WA & 5.94 & & 5 & $\mathrm{mg} / \mathrm{L}$ & FHB013 \\
Tetrachloroethylene & WA & 16.1 & & 5 & $\mathrm{mg} / \mathrm{L}$ & FHB019 \\
Trichloroethylene & WA & 29.7 & & 5 & $\mathrm{mg} / \mathrm{L}$ & FHB013 \\
Trichloroethylene & WA & 13.2 & & 5 & $\mathrm{mg} / \mathrm{L}$ & FHB017 \\
Trichloroethylene & WA & 34.8 & & 5 & $\mathrm{mg} / \mathrm{L}$ & FHB019 \\
Tritium & EMS & 889 & 13.5 & 20 & $\mathrm{pCi} / \mathrm{ml}$ & FHB014 \\
Tritium & EMS & 1520 & 19.3 & 20 & $\mathrm{pCi} / \mathrm{ml}$ & FHB016 \\
Tritium & EMS & 35500 & 346 & 20 & $\mathrm{pCi} / \mathrm{ml}$ & FHB017 \\
Tritium & EMS & 61300 & 572 & 20 & $\mathrm{pCi} / \mathrm{ml}$ & FHB018 \\
Tritium & EMS & 31500 & 308 & 20 & $\mathrm{pCi} / \mathrm{ml}$ & FHB019 \\
Tritium & EMS & 13500 & 125 & 20 & $\mathrm{pCi} / \mathrm{ml}$ & FHB013B \\
\hline
\end{tabular}

Table 7. Analytes Detected at Bucket Locations.

\begin{tabular}{lcc} 
Analyte & $\begin{array}{c}\text { Number of } \\
\text { Buckets }\end{array}$ & $\begin{array}{c}\text { Number of } \\
\text { Detects }\end{array}$ \\
\hline 1,2-Dichloroethylene (total) & 6 & 3 \\
Tetrachloroethylene & 6 & 1 \\
Trichloroethylene & 6 & 1 \\
Tritium & 6 & 6 \\
Vinyl chloride & 6 & 1 \\
\hline
\end{tabular}

Table 8. Analytes and Corresponding Bucket Locations Where August 1994 Concentrations Exceeded the Primary Drinking Water Standards or Maximum Contaminant Levels.

\begin{tabular}{lcccccc} 
Analyte & Lab & Result & Accuracy & Standard & Units & Location \\
\hline 1,2-Dichloroethylene (total) & WA & 85.4 & & 70 & $\mathrm{mg} / \mathrm{L}$ & FHB018B \\
Trichloroethylene & WA & 12.7 & & 5 & $\mathrm{mg} / \mathrm{L}$ & FHB018B \\
Tritium & EMS & 601 & 5.93 & 20 & $\mathrm{pCi} / \mathrm{ml}$ & FHB014B \\
Tritium & EMS & 36800 & 359 & 20 & $\mathrm{pCi} / \mathrm{ml}$ & FHB018B \\
Tritium & EMS & 34.9 & 0.851 & 20 & $\mathrm{pCi} / \mathrm{ml}$ & FHB020B \\
Vinyl chloride & WA & 15.1 & & 2 & $\mathrm{mg} / \mathrm{L}$ & FHB018B \\
\hline
\end{tabular}


Table 9. Comparison of Tritium Results (pCi/mL) from Well and Bucket Locations.

\begin{tabular}{|c|c|c|c|c|}
\hline Location & Analyte & Bucket & Well Point & $\begin{array}{c}\text { Percent } \\
\text { Difference }\end{array}$ \\
\hline BGS002 & Tritium & 3.65 & 7.07 & 48.4 \\
\hline BGS003 & Tritium & 2.69 & 2.53 & -6.3 \\
\hline FHB013 & Tritium & 13500 & 16700 & 19.2 \\
\hline FHB014 & Tritium & 601 & 889 & 32.4 \\
\hline FHB018 & Tritium & 36800 & 61300 & 40.0 \\
\hline FHB020 & Tritium & 34.9 & 18.3 & -90.7 \\
\hline
\end{tabular}




\section{Summary}

Results of the August 1994 sampling event suggest that tritium and volatile organic compounds originating from 643-E are outcropping in the wetlands near the old F-Area effluent ditch. Samples collected from well point and bucket sampling locations contained measurable quantities of organics and tritium. These findings were expected because organics are routinely detected in water table wells in the vicinity of 643-E and shallow groundwater flowing beneath the southwest corner of 643-E outcrops in the wetlands along the old F-Area effluent ditch.

Four different analytes were detected in the well points at least once at concentrations greater than the method detection limit. These analytes included 1,2-dichloroethylene, tetrachloroethylene, trichloroethylene, and tritium. All four analytes were detected at levels above the PDWS or the MCL at one or more locations.

Five analytes, chloromethane, 1,2-dichloroethylene (total), tetrachloroethylene, trichloroethylene. tritium, and vinyl chloride were detected in the buckets, at least once, at concentrations greater than the method detection limit. Tritium, 1,2-dichloroethylene (total), trichloroethylene, and vinyl chloride were detected at concentrations above the limits established by the PDWS or MCL at one or more bucket locations.

An attempt was made to compare analytical results between well point and bucket sampling locations. Differences in tritium concentrations at each location indicated that the different sampling devices, which were installed at different depths, intercepted different groundwater flow paths. This negated direct comparison of analytical results. However, VOC concentrations were normalized based on percent differences in tritium concentrations measured in the well points and buckets. Results suggested that volatilization losses of VOCs from the buckets were negligible. In the future, well points and buckets should be installed to about the same depth for adequate comparisons of the two sampling methodologies. 
WSRC-TR-94-0543 


\section{References}

Dixon, K.L. and C.L. Cummins. 1994. Quarterly Sampling of the Wetlands Along the Old F-Area Effluent Ditch: May 1994. WSRC-TR-94-0365, Westinghouse Savannah River Company, Savannah River Technology Center, Aiken SC.

Dixon, K.L., C.L. Cummins, and V.A. Rogers. 1994. Quarterly Sampling of the Wetlands Along the Old F-Area Effluent Ditch: March 1994. WSRC-TR-94-0225, Westinghouse Savannah River Company, Savannah River Technology Center, Aiken SC.

Dixon, K.L. 1993a. Preliminary results of volatile organic analysis of UTRC-MWMF wetland water samples. SRTESS-93-0658, Westinghouse Savannah River Company, Savannah River Technology Center, Aiken SC.

Dixon, K.L. 1993b. Preliminary results of volatile organic analysis of UTRC-MWMF wetland water samples. SRTESS-93-0751, Westinghouse Savannah River Company, Savannah River Technology Center, Aiken SC.

Dixon, K. L. and V. A. Rogers. 1993a. Results of the quarterly tritium survey of Four Mile Creek and its seeplines in the F- and H- Areas of SRS: June 1993. WSRC-TR-93-0656, Westinghouse Savannah River Company, Savannah River Technology Center, Aiken SC.

Dixon, K. L. and V. A. Rogers. 1993b. Semi-annual sampling of Fourmile Branch and its seeplines in the F- and H-Areas of SRS: July 1992. WSRC-TR-93-289, Westinghouse Savannah River Company, Savannah River Technology Center, Aiken SC.

Environmental Monitoring Section. 1993. The Savannah River Site's Groundwater Monitoring Program, Second Quarter Report. ESH-EMS-930097, Westinghouse Savannah River Company, Aiken SC.

Haselow, J. S., M. Harris, B. B. Looney, N. V. Halverson, and J. B. Gladden. 1990. Analysis of soil and water at the Four Mile Creek seepline near the F- and H-Areas of SRS. WSRC-RP-90-0591, Westinghouse Savannah River Company, Savannah River Technology Center, Aiken SC.

Hoeffner, S. L. 1984. Organics in the Building 643-G burial ground. DPST-84-738, Savannah River Laboratory, Aiken, SC.

Hoeffner, S. L., E. L. Denham, and S.B. Oblath. 1985. Analysis of organics in Building 643-G groundwaters by GC/MS. DPST-85-783, Savannah River Laboratory, Aiken, SC.

Jaegge, W. J., N. L. Kolb, B. B. Looney, I. W. Marine, O. A. Towler, and J. R. Cook. 1985. Radioactive waste burial grounds. DPST-85-694, Savannah River Laboratory, Aiken, SC.

Science Applications International Corporation (SAIC). 1992. Hydrogeologic characterization of the Mixed Waste Management Facility. WSRC-RP-92-837, Rev. 2.0, Westinghouse Savannah River Company, Savannah River Technology Center, Aiken SC.

U. S. Environmental Protection Agency (EPA). 1986. Test Methods for Evaluating Solid Waste, Vol. 1A, 1B, and IC, third edition. SW846. Washington, D.C.

U. S. Environmental Protection Agency (EPA). 1991. National Primary Drinking Water Regulations. Code of Federal Regulations, Title 40, Part 141, pp. 578-715, Washington, DC.

U. S. Environmental Protection Agency (EPA). 1993a. National Primary Drinking Water Regulations-Safe Drinking Water Act Maximum Contaminant Levels (MCL), Code of Federal Regulations, Title 40, Part 141, Washington, DC.

U. S. Environmental Protection Agency (EPA). 1993b. "National Primary Drinking Water Regulations-Safe Drinking Water Act Maximum Contaminant Levels (MCL)", Federal Register, 57FR31776, Effective January 17,1994, Washington, DC.

WSRC-IM-91-53. 1991. Mixed Waste Management Facility Corrective Action Plan-Final Draft. Westinghouse Savannah River Company, Aiken SC. 
WSRC-3Q1-4. 1992a. Determination of tritium in water. Procedure 2760, Rev. 0. Westinghouse Savannah River Company, Aiken SC.

WSRC-3Q5 (Rev.1). 1992b. Hydrogeologic data collection. Westinghouse Savannah River Company, Aiken SC.

WSRC-L14.1. 1993a. Procedure for sampling water table wells in 643-E wetlands-FHB and BGS well series. Procedure 2-115, Rev. 0. Westinghouse Savannah River Company, Aiken SC.

WSRC-L14.1. 1993b. Procedure for seepline and wetland surface water sampling. Procedure 2-104, Rev. 0. Westinghouse Savannah River Company, Aiken SC.

WSRC-L16.1 (Vol. 4). 1993. EPA RCRA Organics. ADS2656. GC/MS for volatile organics-contract laboratory protocol methods. Analytical Development Section-Analytical Operating Procedures. Westinghouse Savannah River Company, Aiken SC. 
Appendix A

August 1994 Analytical Results 


\section{ANALYTICAL RESULTS}

Analytical results from the August 1994 sampling event in the wetlands along the old F-Area effluent ditch are presented in this section. The analytical data for each location (well point and bucket) are presented in tabular format with the background samples presented first followed by the well point samples, bucket samples, and QA/QC samples. Locations ending with the suffix "B" designate bucket sampling locations.

For each sampling location, the results of all field measurements are presented including depth to water (well points only), water level elevation (well points only), $\mathrm{pH}$, and specific conductance. This information is followed by all laboratory analyses for each location. For each analyte in the laboratory analyses tables, the following information is presented: the lab that performed the analysis, any result and analysis qualifiers, the analytical results, any appropriate standard for comparison, and the units in which the results are presented.

The following is a list of abbreviations used in the tables:

Lab Laboratory performing analysis

Mod Result or analysis qualifier

Rep Replicate sample (denoted by "R")

Avg Average code

"A" - reference sample averaged with lab duplicates for that sample

"NA" - reference sample not averaged with lab duplicates for that sample

WA Weston Analytics

ADS Analytical Development Section

EMS Environmental Monitoring Section

Result and Analysis Qualifiers

\begin{tabular}{|l|l|}
\hline \multicolumn{2}{|l|}{ Result Qualifiers } \\
\hline CODE & DESCRIPTION \\
\hline (BLANK) & Data not remarked. Number should be interpreted exactly as reported. \\
\hline $\mathrm{J}$ & The analytical result is an estimated quantity. \\
\hline $\mathrm{R}$ & $\begin{array}{l}\text { Rejected because of performance requirements in the sample or associated quality } \\
\text { control analyses were not met. The analyte may or may not be present. }\end{array}$ \\
\hline $\mathrm{U}$ & $\begin{array}{l}\text { Material analyzed for but not detected. Value reported is the sample quantification } \\
\text { limit. }\end{array}$ \\
\hline
\end{tabular}

\begin{tabular}{|l|l|}
\hline \multicolumn{2}{|l|}{ Analysis Qualifiers } \\
\hline CODE & DESCRIPTION \\
\hline Q & $\begin{array}{l}\text { Sample held beyond normal holding time. If holding time is exceeded by less than } 30 \\
\text { days, used with "J". If holding time is exceeded by more than } 30 \text { days, used with "R". }\end{array}$ \\
\hline V & Indicates the analyte was detected in both the sample and associated method blank. \\
\hline
\end{tabular}


BGS002

Field Measurements:

Sample Date: 08/25/94

Depth to Water: $5.5 \mathrm{ft}$ below TOC

Water Level Elevation: $176 \mathrm{msl}$

$\mathrm{pH}: 4.81$

Conductivity: $44 \mu \mathrm{S} / \mathrm{cm}$

\begin{tabular}{|c|c|c|c|c|c|c|c|c|}
\hline Analyte & Lab & Rep & Avg & Qualifier & Result & Acc & Standard & Units \\
\hline 1,1,1,2-Tetrachloroethane & WA & & NA & $\bar{U}$ & 10 & & NS & $\mu \mathrm{g} / \mathrm{L}$ \\
\hline 1,1,1,2-Tetrachloroethane & WA & & NA & $\mathrm{U}$ & 10 & & NS & $\mu \mathrm{g} / \mathrm{L}$ \\
\hline 1,1,1,2-Tetrachloroethane & WA & & & $\mathrm{U}$ & 10 & & NS & $\mu \mathrm{g} / \mathrm{L}$ \\
\hline 1,1,1-Trichloroethane & WA & & NA & $\mathrm{U}$ & 5 & & 200 & $\mu \mathrm{g} / \mathrm{L}$ \\
\hline 1,1,1-Trichloroethane & WA & & NA & $\mathrm{U}$ & 5 & & 200 & $\mu \mathrm{g} / \mathrm{L}$ \\
\hline 1,1,1-Trichloroethane & WA & & & U & 5 & & 200 & $\mu \mathrm{g} / \mathrm{L}$ \\
\hline 1,1,2,2-Tetrachloroethane & WA & & NA & U & 5 & & NS & $\mu \mathrm{g} / \mathrm{L}$ \\
\hline 1,1,2,2-Tetrachloroethane & WA & & NA & $\mathrm{U}$ & 5 & & NS & $\mu \mathrm{g} / \mathrm{L}$ \\
\hline 1,1,2,2-Tetrachloroethane & WA & & & $\mathrm{U}$ & 5 & & NS & $\mu \mathrm{g} / \mathrm{L}$ \\
\hline 1,1,2-Trichloroethane & WA & & NA & $\mathrm{U}$ & 5 & & 5 & $\mu \mathrm{g} / \mathrm{L}$ \\
\hline 1,1,2-Trichloroethane & WA & & NA & $\mathrm{U}$ & 5 & & 5 & $\mu \mathrm{g} / \mathrm{L}$ \\
\hline 1,1,2-Trichloroethane & WA & & & U & 5 & & 5 & $\mu \mathrm{g} / \mathrm{L}$ \\
\hline 1,1-Dichloroethane & WA & & NA & U & 5 & & NS & $\mu \mathrm{g} / \mathrm{L}$ \\
\hline 1,1-Dichloroethane & WA & & & $\mathrm{U}$ & 5 & & NS & $\mu g / L$ \\
\hline 1,1-Dichloroethane & WA & & NA & $\mathrm{U}$ & 5 & & NS & $\mu \mathrm{g} / \mathrm{L}$ \\
\hline 1,1-Dichloroethylene & WA & & & $\mathrm{U}$ & 5 & & 7 & $\mu \mathrm{g} / \mathrm{L}$ \\
\hline 1,2,3-Trichloropropane & WA & & NA & $\mathbf{U}$ & 10 & & NS & $\mu \mathrm{g} / \mathrm{L}$ \\
\hline 1,2,3-Trichloropropane & WA & & NA & $\mathbf{U}$ & 10 & & NS & $\mu \mathrm{g} / \mathrm{L}$ \\
\hline 1,2,3-Trichloropropane & WA & & & $\mathrm{U}$ & 10 & & NS & $\mu g / L$ \\
\hline 1,2-Dibromo-3-chloropropane & WA & & NA & $\mathrm{U}$ & 20 & & 0.2 & $\mu \mathrm{g} / \mathrm{L}$ \\
\hline 1,2-Dibromo-3-chloropropane & WA & & NA & $\mathrm{U}$ & 20 & & 0.2 & $\mu \mathrm{g} / \mathrm{L}$ \\
\hline 1,2-Dibromo-3-chloropropane & WA & & & $\mathrm{U}$ & 20 & & 0.2 & $\mu \mathrm{g} / \mathrm{L}$ \\
\hline 1,2-Dibromoethane & WA & & NA & $\mathrm{U}$ & 20 & & NS & $\mu \mathrm{g} / \mathrm{L}$ \\
\hline 1,2-Dibromoethane & WA & & NA & $\mathrm{U}$ & 20 & & NS & $\mu g / L$ \\
\hline 1,2-Dibromoethane & WA & & & $\mathrm{U}$ & 20 & & NS & $\mu \mathrm{g} / \mathrm{L}$ \\
\hline 1,2-Dichloroethane & WA & & & $\mathbf{U}$ & 5 & & 5 & $\mu \mathrm{g} / \mathrm{L}$ \\
\hline 1,2-Dichloroethane & WA & & NA & $\mathbf{U}$ & 5 & & 5 & $\mu g / L$ \\
\hline 1,2-Dichloroethane & WA & & NA & $\mathbf{U}$ & 5 & & 5 & $\mu g / L$ \\
\hline 1,2-Dichloroethylene (total) & WA & & NA & $\mathrm{U}$ & 5 & & 70 & $\mu \mathrm{g} / \mathrm{L}$ \\
\hline 1,2-Dichloroethylene (total) & WA & & NA & $\mathrm{U}$ & 5 & & 70 & $\mu g / L$ \\
\hline 1,2-Dichloroethylene (total) & WA & & & $\mathrm{U}$ & 5 & & 70 & $\mu g / L$ \\
\hline 1,2-Dichloropropane & WA & & NA & $\mathrm{U}$ & 5 & & 5 & $\mu g / L$ \\
\hline 1,2-Dichloropropane & WA & & & $\mathrm{U}$ & 5 & & 5 & $\mu \mathrm{g} / \mathrm{L}$ \\
\hline 1,2-Dichloropropane & WA & & $\mathrm{NA}$ & $\mathrm{U}$ & 5 & & 5 & $\mu \mathrm{g} / \mathrm{L}$ \\
\hline 2-Hexanone & WA & & & $\mathbf{U}$ & 10 & & NS & $\mu \mathrm{g} / \mathrm{L}$ \\
\hline 2-Hexanone & WA & & $\mathrm{NA}$ & $\mathrm{U}$ & 10 & & NS & $\mu \mathrm{g} / \mathrm{L}$ \\
\hline 2-Hexanone & WA & & NA & $\mathbf{U}$ & 10 & & NS & $\mu g / L$ \\
\hline 4-Methyl-2-pentanone & WA & & & $\mathrm{U}$ & 10 & & NS & $\mu \mathrm{g} / \mathrm{L}$ \\
\hline 4-Methyl-2-pentanone & WA & & $\mathrm{NA}$ & $\mathrm{U}$ & 10 & & NS & $\mu \mathrm{g} / \mathrm{L}$ \\
\hline
\end{tabular}


BGS002 (cont'd)

\begin{tabular}{|c|c|c|c|c|c|c|c|c|}
\hline Analyte & $\mathrm{Lab}$ & Rep & Avg & Qualifier & Result & Acc & Standard & Units \\
\hline Acetone & WA & & & $\bar{U}$ & 10 & & NS & $\mu \mathrm{g} / \mathrm{L}$ \\
\hline Acetone & WA & & $\mathrm{NA}$ & $\mathrm{U}$ & 10 & & NS & $\mu \mathrm{g} / \mathrm{L}$ \\
\hline Acetone & WA & & NA & $\mathrm{U}$ & 10 & & NS & $\mu g / L$ \\
\hline Acetonitrile (Methyl cyanide) & WA & & NA & $\mathrm{U}$ & 20 & & NS & $\mu \mathrm{g} / \mathrm{L}$ \\
\hline Acetonitrile (Methyl cyanide) & WA & & NA & $\mathrm{U}$ & 20 & & NS & $\mu \mathrm{g} / \mathrm{L}$ \\
\hline Acetonitrile (Methyl cyanide) & WA & & & $\mathrm{U}$ & 20 & & NS & $\mu \mathrm{g} / \mathrm{L}$ \\
\hline Acrolein & WA & & & $U$ & 10 & & NS & $\mu \mathrm{g} / \mathrm{L}$ \\
\hline Acrolein & WA & & NA & $U$ & 10 & & NS & $\mu \mathrm{g} / \mathrm{L}$ \\
\hline Acrolein & WA & & $\mathrm{NA}$ & $\mathrm{U}$ & 10 & & NS & $\mu \mathrm{g} / \mathrm{L}$ \\
\hline Acrylonitrile & WA & & & $\mathrm{U}$ & 10 & & NS & $\mu \mathrm{g} / \mathrm{L}$ \\
\hline Acrylonitrile & WA & & NA & $\mathbf{U}$ & 10 & & NS & $\mu \mathrm{g} / \mathrm{L}$ \\
\hline Acrylonitrile & WA & & NA & $\mathrm{U}$ & 10 & & NS & $\mu \mathrm{g} / \mathrm{L}$ \\
\hline Allyl chloride & WA & & NA & $\mathrm{U}$ & 100 & & NS & $\mu \mathrm{g} / \mathrm{L}$ \\
\hline Allyl chloride & WA & & NA & $\mathrm{U}$ & 100 & & NS & $\mu \mathrm{g} / \mathrm{L}$ \\
\hline Allyl chloride & WA & & & $\mathrm{U}$ & 100 & & NS & $\mu \mathrm{g} / \mathrm{L}$ \\
\hline Benzene & WA & & & $\mathrm{U}$ & 5 & & 5 & $\mu \mathrm{g} / \mathrm{L}$ \\
\hline Bromodichloromethane & WA & & & $U$ & 5 & & NS & $\mu \mathrm{g} / \mathrm{L}$ \\
\hline Bromodichloromethane & WA & & NA & $\mathrm{U}$ & 5 & & NS & $\mu \mathrm{g} / \mathrm{L}$ \\
\hline Bromodichloromethane & WA & & NA & $\mathrm{U}$ & 5 & & NS & $\mu \mathrm{g} / \mathrm{L}$ \\
\hline Bromoform & WA & & NA & $\mathbf{U}$ & 5 & & NS & $\mu \mathrm{g} / \mathrm{L}$ \\
\hline Bromoform & WA & & NA & $\mathrm{U}$ & 5 & & NS & $\mu \mathrm{g} / \mathrm{L}$ \\
\hline Bromoform & WA & & & $\mathrm{U}$ & 5 & & NS & $\mu \mathrm{g} / \mathrm{L}$ \\
\hline Carbon disulfide & WA & & NA & $\mathrm{U}$ & 5 & & NS & $\mu \mathrm{g} / \mathrm{L}$ \\
\hline Carbon disulfide & WA & & & $\mathrm{U}$ & 5 & & NS & $\mu g / L$ \\
\hline Carbon disulfide & WA & & NA & $\mathrm{U}$ & 5 & & NS & $\mu \mathrm{g} / \mathrm{L}$ \\
\hline Carbon tetrachloride & WA & & & $\mathrm{U}$ & 5 & & 5 & $\mu \mathrm{g} / \mathrm{L}$ \\
\hline Carbon tetrachloride & WA & & NA & $\mathrm{U}$ & 5 & & 5 & $\mu \mathrm{g} / \mathrm{L}$ \\
\hline Carbon tetrachloride & WA & & NA & $\mathrm{U}$ & 5 & & 5 & $\mu \mathrm{g} / \mathrm{L}$ \\
\hline Chlorobenzene & WA & & & $\mathbf{U}$ & 5 & & 100 & $\mu \mathrm{g} / \mathrm{L}$ \\
\hline Chloroethane & WA & & NA & $\mathbf{U}$ & 10 & & NS & $\mu \mathrm{g} / \mathrm{L}$ \\
\hline Chloroethane & WA & & NA & $\mathrm{U}$ & 10 & & NS & $\mu g / L$ \\
\hline Chloroethane & WA & & & $U$ & 10 & & NS & $\mu \mathrm{g} / \mathrm{L}$ \\
\hline Chloroform & WA & & NA & $\mathrm{U}$ & 5 & & 100 & $\mu \mathrm{g} / \mathrm{L}$ \\
\hline Chloroform & WA & & $\mathrm{NA}$ & $U$ & 5 & & 100 & $\mu \mathrm{g} / \mathrm{L}$ \\
\hline Chloroform & WA & & & $\mathrm{U}$ & 5 & & 100 & $\mu \mathrm{g} / \mathrm{L}$ \\
\hline Chloroprene & WA & & NA & $U$ & 20 & & NS & $\mu \mathrm{g} / \mathrm{L}$ \\
\hline Chloroprene & WA & & NA & $\mathrm{U}$ & 20 & & NS & $\mu \mathrm{g} / \mathrm{L}$ \\
\hline Chloroprene & WA & & & $\mathrm{U}$ & 20 & & NS & $\mu \mathrm{g} / \mathrm{L}$ \\
\hline cis-1,3-Dichloropropene & WA & & & $\mathrm{U}$ & 5 & & NS & $\mu \mathrm{g} / \mathrm{L}$ \\
\hline cis-1,3-Dichloropropene & WA & & NA & $\mathrm{U}$ & 5 & & NS & $\mu \mathrm{g} / \mathrm{L}$ \\
\hline cis-1,3-Dichloropropene & WA & & NA & $\mathrm{U}$ & 5 & & NS & $\mu \mathrm{g} / \mathrm{L}$ \\
\hline Dibromochloromethane & WA & & NA & $\mathrm{U}$ & 5 & & NS & $\mu g / L$ \\
\hline Dibromochloromethane & WA & & NA & $\mathrm{U}$ & 5 & & NS & $\mu \mathrm{g} / \mathrm{L}$ \\
\hline Dibromochloromethane & WA & & & $\mathrm{U}$ & 5 & & NS & $\mu \mathrm{g} / \mathrm{L}$ \\
\hline Dichlorodifluoromethane & WA & & NA & $\mathrm{U}$ & 10 & & NS & $\mu \mathrm{g} / \mathrm{L}$ \\
\hline Dichlorodifluoromethane & WA & & NA & $U$ & 10 & & NS & $\mu g / L$ \\
\hline Dichlorodifluoromethane & WA & & & $\mathrm{U}$ & 10 & & NS & $\mu \mathrm{g} / \mathrm{L}$ \\
\hline
\end{tabular}


BGS002 (cont'd)

\begin{tabular}{|c|c|c|c|c|c|c|c|c|}
\hline Analyte & $\mathrm{Lab}$ & Rep & Avg & Qualifier & Result & Acc & Standard & Units \\
\hline Ethylbenzene & WA & & & $\mathrm{U}$ & 5 & & 700 & $\mu \mathrm{g} / \mathrm{L}$ \\
\hline Ethylbenzene & WA & & $\mathrm{NA}$ & $U$ & 5 & & 700 & $\mu \mathrm{g} / \mathrm{L}$ \\
\hline Ethylbenzene & WA & & NA & U & 5 & & 700 & $\mu \mathrm{g} / \mathrm{L}$ \\
\hline Isobutyl alcohol & WA & & NA & $\mathrm{U}$ & 20 & & NS & $\mu \mathrm{g} / \mathrm{L}$ \\
\hline Isobutyl alcohol & WA & & & $\mathrm{U}$ & 20 & & NS & $\mu \mathrm{g} / \mathrm{L}$ \\
\hline Isobutyl alcohol & WA & & NA & U & 20 & & NS & $\mu \mathrm{g} / \mathrm{L}$ \\
\hline Methacrylonitrile & WA & & NA & U & 20 & & NS & $\mu \mathrm{g} / \mathrm{L}$ \\
\hline Methacrylonitrile & WA & & NA & $\mathrm{U}$ & 20 & & NS & $\mu \mathrm{g} / \mathrm{L}$ \\
\hline Methacrylonitrile & WA & & & $\mathrm{U}$ & 20 & & NS & $\mu \mathrm{g} / \mathrm{L}$ \\
\hline Methyl bromide & WA & & & $U$ & 10 & & NS & $\mu g / L$ \\
\hline Methyl bromide & WA & & NA & $U$ & 10 & & NS & $\mu \mathrm{g} / \mathrm{L}$ \\
\hline Methyl bromide & WA & & NA & $U$ & 10 & & NS & $\mu \mathrm{g} / \mathrm{L}$ \\
\hline Methyl chloride & WA & & & $\mathrm{U}$ & 10 & & NS & $\mu \mathrm{g} / \mathrm{L}$ \\
\hline Methyl chloride & WA & & $\mathrm{NA}$ & $\mathrm{U}$ & 10 & & NS & $\mu \mathrm{g} / \mathrm{L}$ \\
\hline Methyl chloride & WA & & NA & $\mathrm{U}$ & 10 & & NS & $\mu \mathrm{g} / \mathrm{L}$ \\
\hline Methyl ethyl ketone & WA & & NA & $\mathrm{U}$ & 10 & & NS & $\mu \mathrm{g} / \mathrm{L}$ \\
\hline Methyl ethyl ketone & WA & & $\mathrm{NA}$ & $\mathrm{U}$ & 10 & & NS & $\mu \mathrm{g} / \mathrm{L}$ \\
\hline Methyl ethyl ketone & WA & & & $\mathrm{U}$ & 10 & & NS & $\mu \mathrm{g} / \mathrm{L}$ \\
\hline Methyl iodide & WA & & NA & $U$ & 10 & & NS & $\mu \mathrm{g} / \mathrm{L}$ \\
\hline Methyl iodide & WA & & NA & $\mathrm{U}$ & 10 & & NS & $\mu \mathrm{g} / \mathrm{L}$ \\
\hline Methyl iodide & WA & & & $\mathrm{U}$ & 10 & & NS & $\mu \mathrm{g} / \mathrm{L}$ \\
\hline Methylene bromide & WA & & NA & $\mathrm{U}$ & 10 & & NS & $\mu g / L$ \\
\hline Methylene bromide & WA & & & $U$ & 10 & & NS & $\mu \mathrm{g} / \mathrm{L}$ \\
\hline Methylene bromide & WA & & NA & $\mathbf{U}$ & 10 & & NS & $\mu \mathrm{g} / \mathrm{L}$ \\
\hline Methylene chloride & WA & & NA & $\mathrm{J}$ & 1.3 & & 5 & $\mu \mathrm{g} / \mathrm{L}$ \\
\hline Methylene chloride & WA & & $\mathrm{NA}$ & J & 1.37 & & 5 & $\mu \mathrm{g} / \mathrm{L}$ \\
\hline Methylene chloride & WA & & & $\mathrm{U}$ & 5 & & 5 & $\mu \mathrm{g} / \mathrm{L}$ \\
\hline Propionitrile & WA & & NA & $U$ & 50 & & NS & $\mu \mathrm{g} / \mathrm{L}$ \\
\hline Propionitrile & WA & & $\mathrm{NA}$ & $\mathrm{U}$ & 50 & & NS & $\mu \mathrm{g} / \mathrm{L}$ \\
\hline Propionitrile & WA & & & $\mathrm{U}$ & 50 & & NS & $\mu \mathrm{g} / \mathrm{L}$ \\
\hline Styrene & WA & & & $\mathrm{U}$ & 5 & & 100 & $\mu \mathrm{g} / \mathrm{L}$ \\
\hline Styrene & WA & & $\mathrm{NA}$ & $\mathrm{U}$ & 5 & & 100 & $\mu \mathrm{g} / \mathrm{L}$ \\
\hline Styrene & WA & & NA & $\mathrm{U}$ & 5 & & 100 & $\mu \mathrm{g} / \mathrm{L}$ \\
\hline Tetrachloroethylene & WA & & NA & U & 5 & & 5 & $\mu \mathrm{g} / \mathrm{L}$ \\
\hline Tetrachloroethylene & WA & & & $\mathrm{U}$ & 5 & & 5 & $\mu \mathrm{g} / \mathrm{L}$ \\
\hline Tetrachloroethylene & WA & & $\mathrm{NA}$ & $\mathrm{U}$ & 5 & & 5 & $\mu \mathrm{g} / \mathrm{L}$ \\
\hline Toluene & WA & & & U & 5 & & 1000 & $\mu \mathrm{g} / \mathrm{L}$ \\
\hline trans-1,3-Dichloropropene & WA & & & $\mathbf{U}$ & 5 & & NS & $\mu g / L$ \\
\hline trans-1,3-Dichloropropene & WA & & NA & $\mathrm{U}$ & 5 & & NS & $\mu \mathrm{g} / \mathrm{L}$ \\
\hline trans-1,3-Dichloropropene & WA & & NA & $\mathrm{U}$ & 5 & & NS & $\mu \mathrm{g} / \mathrm{L}$ \\
\hline trans-1,4-Dichloro-2-butene & WA & & & $\mathrm{U}$ & 100 & & NS & $\mu \mathrm{g} / \mathrm{L}$ \\
\hline trans-1,4-Dichloro-2-butene & WA & & NA & $\mathrm{U}$ & 100 & & NS & $\mu \mathrm{g} / \mathrm{L}$ \\
\hline trans-1,4-Dichloro-2-butene & WA & & NA & $\mathrm{U}$ & 100 & & NS & $\mu \mathrm{g} / \mathrm{L}$ \\
\hline Trichloroethylene & WA & & & $\mathrm{U}$ & 5 & & 5 & $\mu \mathrm{g} / \mathrm{L}$ \\
\hline
\end{tabular}


BGS002 (cont'd)

\begin{tabular}{|c|c|c|c|c|c|c|c|c|}
\hline Analyte & Lab & Rep & Avg & Qualifier & Result & Acc & Standard & Units \\
\hline Trichlorofluoromethane & $\overline{\text { WA }}$ & & $\mathrm{NA}$ & $\bar{U}$ & 5 & & NS & $\mu \mathrm{g} / \mathrm{L}$ \\
\hline Trichlorofluoromethane & WA & & & U & 5 & & NS & $\mu \mathrm{g} / \mathrm{L}$ \\
\hline Tritium & EMS & & & & 7.07 & 0.49 & 20 & $\mathrm{pCi} / \mathrm{ml}$ \\
\hline Vinyl acetate & WA & & $\mathrm{NA}$ & $\mathrm{U}$ & 10 & & NS & $\mu g / L$ \\
\hline Vinyl acetate & WA & & & $\mathbf{U}$ & 10 & & NS & $\mu \mathrm{g} / \mathrm{L}$ \\
\hline Vinyl acetate & WA & & NA & $\mathrm{U}$ & 10 & & NS & $\mu \mathrm{g} / \mathrm{L}$ \\
\hline Vinyl chloride & WA & & NA & U & 10 & & 2 & $\mu \mathrm{g} / \mathrm{L}$ \\
\hline Vinyl chloride & WA & & NA & $\mathrm{U}$ & 10 & & 2 & $\mu \mathrm{g} / \mathrm{L}$ \\
\hline Vinyl chloride & WA & & & $\mathrm{U}$ & 10 & & 2 & $\mu \mathrm{g} / \mathrm{L}$ \\
\hline Xylenes (total) & WA & & NA & $\mathrm{U}$ & 5 & & 10000 & $\mu \mathrm{g} / \mathrm{L}$ \\
\hline Xylenes (total) & WA & & & $\mathrm{U}$ & 5 & & 10000 & $\mu g / L$ \\
\hline Xylenes (total) & WA & & NA & U & 5 & & 10000 & $\mu g / L$ \\
\hline
\end{tabular}


BGS002B

Field Measurements:

Sample Date: 08/25/94

pH: 4.77

Conductivity: $28 \mu \mathrm{S} / \mathrm{cm}$

\begin{tabular}{|c|c|c|c|c|c|c|c|c|}
\hline Analyte & $\mathrm{Lab}$ & Rep & Avg & Qualifier & Result & Acc & Standard & Units \\
\hline 1,1,1,2-Tetrachloroethane & WA & & & $\bar{U}$ & 10 & & NS & $\mu \mathrm{g} / \mathrm{L}$ \\
\hline 1,1,1-Trichloroethane & WA & & & $\mathrm{U}$ & 5 & & 200 & $\mu \mathrm{g} / \mathrm{L}$ \\
\hline 1,1,2,2-Tetrachloroethane & WA & & & $\mathrm{U}$ & 5 & & NS & $\mu \mathrm{g} / \mathrm{L}$ \\
\hline 1,1,2-Trichloroethane & WA & & & $\mathrm{U}$ & 5 & & 5 & $\mu \mathrm{g} / \mathrm{L}$ \\
\hline 1,1-Dichloroethane & WA & & & U & 5 & & NS & $\mu \mathrm{g} / \mathrm{L}$ \\
\hline 1,1-Dichloroethylene & WA & & & $\mathrm{U}$ & 5 & & 7 & $\mu \mathrm{g} / \mathrm{L}$ \\
\hline 1,2,3-Trichloropropane & WA & & & $\mathrm{U}$ & 10 & & NS & $\mu \mathrm{g} / \mathrm{L}$ \\
\hline 1,2-Dibromo-3-chloropropane & WA & & & $\mathrm{U}$ & 20 & & 0.2 & $\mu \mathrm{g} / \mathrm{L}$ \\
\hline 1,2-Dibromoethane & WA & & & $\mathrm{U}$ & 20 & & NS & $\mu \mathrm{g} / \mathrm{L}$ \\
\hline 1,2-Dichloroethane & WA & & & $U$ & 5 & & 5 & $\mu \mathrm{g} / \mathrm{L}$ \\
\hline 1,2-Dichloroethylene (total) & WA & & & $\mathrm{U}$ & 5 & & 70 & $\mu \mathrm{g} / \mathrm{L}$ \\
\hline 1,2-Dichloropropane & WA & & & $\mathrm{U}$ & 5 & & 5 & $\mu \mathrm{g} / \mathrm{L}$ \\
\hline 2-Hexanone & WA & & & $\mathrm{U}$ & 10 & & NS & $\mu \mathrm{g} / \mathrm{L}$ \\
\hline 4-Methyl-2-pentanone & WA & & & $\mathrm{U}$ & 10 & & NS & $\mu \mathrm{g} / \mathrm{L}$ \\
\hline Acetone & WA & & & $\mathrm{U}$ & 10 & & NS & $\mu g / L$ \\
\hline Acetonitrile (Methyl cyanide) & WA & & & U & 20 & & NS & $\mu \mathrm{g} / \mathrm{L}$ \\
\hline Acrolein & WA & & & $\mathrm{U}$ & 10 & & NS & $\mu \mathrm{g} / \mathrm{L}$ \\
\hline Acrylonitrile & WA & & & $\mathbf{U}$ & 10 & & NS & $\mu \mathrm{g} / \mathrm{L}$ \\
\hline Allyl chloride & WA & & & $\mathrm{U}$ & 100 & & NS & $\mu \mathrm{g} / \mathrm{L}$ \\
\hline Benzene & WA & & & $\mathrm{U}$ & 5 & & 5 & $\mu \mathrm{g} / \mathrm{L}$ \\
\hline Bromodichloromethane & WA & & & $\mathbf{U}$ & 5 & & NS & $\mu \mathrm{g} / \mathrm{L}$ \\
\hline Bromoform & WA & & & $\mathrm{U}$ & 5 & & NS & $\mu \mathrm{g} / \mathrm{L}$ \\
\hline Carbon disulfide & WA & & & $\mathbf{U}^{\prime}$ & 5 & & NS & $\mu \mathrm{g} / \mathrm{L}$ \\
\hline Carbon tetrachloride & WA & & & $\mathbf{U}^{\prime}$ & 5 & & 5 & $\mu \mathrm{g} / \mathrm{L}$ \\
\hline Chlorobenzene & WA & & & $\mathrm{U}$ & 5 & & 100 & $\mu \mathrm{g} / \mathrm{L}$ \\
\hline Chloroethane & WA & & & $\mathrm{U}$ & 10 & & NS & $\mu \mathrm{g} / \mathrm{L}$ \\
\hline Chloroform & WA & & & $\mathrm{U}$ & 5 & & 100 & $\mu \mathrm{g} / \mathrm{L}$ \\
\hline Chloroprene & WA & & & $\mathrm{U}$ & 20 & & NS & $\mu g / L$ \\
\hline cis-1,3-Dichloropropene & WA & & & $\mathrm{U}$ & 5 & & NS & $\mu \mathrm{g} / \mathrm{L}$ \\
\hline Dibromochloromethane & WA & & & $\mathrm{U}$ & 5 & & NS & $\mu \mathrm{g} / \mathrm{L}$ \\
\hline Dichlorodifluoromethane & WA & & & $\mathrm{U}$ & 10 & & NS & $\mu \mathrm{g} / \mathrm{L}$ \\
\hline Ethylbenzene & WA & & & $\mathrm{U}$ & 5 & & 700 & $\mu \mathrm{g} / \mathrm{L}$ \\
\hline Isobutyl alcohol & WA & & & $\mathbf{U}$ & 20 & & NS & $\mu \mathrm{g} / \mathrm{L}$ \\
\hline Methacrylonitrile & WA & & & $\mathrm{U}$ & 20 & & NS & $\mu \mathrm{g} / \mathrm{L}$ \\
\hline Methyl bromide & WA & & & $\mathrm{U}$ & 10 & & NS & $\mu g / L$ \\
\hline Methyl chloride & WA & & & $\mathbf{J}$ & 3.92 & & NS & $\mu \mathrm{g} / \mathrm{L}$ \\
\hline Methyl ethyl ketone & WA & & & $\mathrm{U}$ & 10 & & NS & $\mu \mathrm{g} / \mathrm{L}$ \\
\hline Methyl iodide & WA & & & $\mathrm{U}$ & 10 & & NS & $\mu \mathrm{g} / \mathrm{L}$ \\
\hline Methylene bromide & WA & & & $\mathrm{U}$ & 10 & & NS & $\mu \mathrm{g} / \mathrm{L}$ \\
\hline Methylene chloride & WA & & & $\mathrm{U}$ & 5 & & 5 & $\mu g / L$ \\
\hline Propionitrile & WA & & & $\mathrm{U}$ & 50 & & NS & $\mu \mathrm{g} / \mathrm{L}$ \\
\hline
\end{tabular}


BGS002B (cont'd)

\begin{tabular}{|c|c|c|c|c|c|c|c|c|}
\hline Analyte & Lab & Rep & Avg & Qualifier & Result & Acc & Standard & Units \\
\hline Styrene & WA & & & $\mathrm{U}$ & 5 & & 100 & $\mu \mathrm{g} / \mathrm{L}$ \\
\hline Tetrachloroethylene & WA & & & U & 5 & & 5 & $\mu \mathrm{g} / \mathrm{L}$ \\
\hline Toluene & WA & & & $\mathrm{U}$ & 5 & & 1000 & $\mu \mathrm{g} / \mathrm{L}$ \\
\hline trans-1,3-Dichloropropene & WA & & & $\mathrm{U}$ & 5 & & NS & $\mu \mathrm{g} / \mathrm{L}$ \\
\hline trans-1,4-Dichloro-2-butene & WA & & & $\mathrm{U}$ & 100 & & NS & $\mu \mathrm{g} / \mathrm{L}$ \\
\hline Trichloroethylene & WA & & & $\mathrm{U}$ & 5 & & 5 & $\mu \mathrm{g} / \mathrm{L}$ \\
\hline Trichlorofluoromethane & WA & & & $\mathrm{U}$ & 5 & & NS & $\mu \mathrm{g} / \mathrm{L}$ \\
\hline Tritium & EMS & & & & 3.65 & 0.43 & 20 & $\mathrm{pCi} / \mathrm{ml}$ \\
\hline Vinyl acetate & WA & & & $\mathbf{U}$ & 10 & & NS & $\mu \mathrm{g} / \mathrm{L}$ \\
\hline Vinyl chloride & WA & & & U & 10 & & 2 & $\mu \mathrm{g} / \mathrm{L}$ \\
\hline Xylenes (total) & WA & & & $\mathrm{U}$ & 5 & & 10000 & $\mu \mathrm{g} / \mathrm{L}$ \\
\hline
\end{tabular}




\section{BGS003}

Field Measurements:

Sample Date: 08/26/94

Depth to Water: $3.57 \mathrm{ft}$ below TOC

Water Level Elevation: $177 \mathrm{msl}$

pH: 4.97

Conductivity: $24 \mu \mathrm{S} / \mathrm{cm}$

\begin{tabular}{|c|c|c|c|c|c|c|c|}
\hline Analyte & $\mathrm{Lab}$ & Rep & Qualifier & Result & Acc & Standard & Units \\
\hline 1,1,1,2-Tetrachloroethane & WA & & $\overline{\mathrm{U}}$ & 10 & & NS & $\mu \mathrm{g} / \mathrm{L}$ \\
\hline 1,1,1-Trichloroethane & WA & & $\mathrm{U}$ & 5 & & 200 & $\mu \mathrm{g} / \mathrm{L}$ \\
\hline 1,1,2,2-Tetrachloroethane & WA & & $\mathrm{U}$ & 5 & & NS & $\mu \mathrm{g} / \mathrm{L}$ \\
\hline 1,1,2-Trichloroethane & WA & & $\mathrm{U}$ & 5 & & 5 & $\mu \mathrm{g} / \mathrm{L}$ \\
\hline 1,1-Dichloroethane & WA & & $\mathrm{U}$ & 5 & & NS & $\mu \mathrm{g} / \mathrm{L}$ \\
\hline 1,1-Dichloroethylene & WA & & $\mathrm{U}$ & 5 & & 7 & $\mu \mathrm{g} / \mathrm{L}$ \\
\hline 1,2,3-Trichloropropane & WA & & $\mathrm{U}$ & 10 & & NS & $\mu g / L$ \\
\hline 1,2-Dibromo-3-chloropropane & WA & & $\mathrm{U}$ & 20 & & 0.2 & $\mu \mathrm{g} / \mathrm{L}$ \\
\hline 1,2-Dibromoethane & WA & & $\mathrm{U}$ & 20 & & NS & $\mu \mathrm{g} / \mathrm{L}$ \\
\hline 1,2-Dichloroethane & WA & & $\mathrm{U}$ & 5 & & 5 & $\mu \mathrm{g} / \mathrm{L}$ \\
\hline 1,2-Dichloroethylene (total) & WA & & $\mathbf{U}$ & 5 & & 70 & $\mu \mathrm{g} / \mathrm{L}$ \\
\hline 1,2-Dichloropropane & WA & & $\mathrm{U}$ & 5 & & 5 & $\mu \mathrm{g} / \mathrm{L}$ \\
\hline 2-Hexanone & WA & & $\mathrm{U}$ & 10 & & NS & $\mu \mathrm{g} / \mathrm{L}$ \\
\hline 4-Methyl-2-pentanone & WA & & $\mathbf{U}$ & 10 & & NS & $\mu \mathrm{g} / \mathrm{L}$ \\
\hline Acetone & WA & & $\mathrm{V}$ & 10.5 & & NS & $\mu \mathrm{g} / \mathrm{L}$ \\
\hline Acetonitrile (Methyl cyanide) & WA & & $\mathrm{U}$ & 20 & & NS & $\mu \mathrm{g} / \mathrm{L}$ \\
\hline Acrolein & WA & & $\mathrm{U}$ & 10 & & NS & $\mu \mathrm{g} / \mathrm{L}$ \\
\hline Acrylonitrile & WA & & $\mathrm{U}$ & 10 & & NS & $\mu \mathrm{g} / \mathrm{L}$ \\
\hline Allyl chloride & WA & & $\mathrm{U}$ & 100 & & NS & $\mu \mathrm{g} / \mathrm{L}$ \\
\hline Benzene & WA & & $\mathrm{U}$ & 5 & & 5 & $\mu \mathrm{g} / \mathrm{L}$ \\
\hline Bromodichloromethane & WA & & $\mathrm{U}$ & 5 & & NS & $\mu \mathrm{g} / \mathrm{L}$ \\
\hline Bromoform & WA & & $\mathrm{U}$ & 5 & & NS & $\mu \mathrm{g} / \mathrm{L}$ \\
\hline Carbon disulfide & WA & & $U$ & 5 & & NS & $\mu \mathrm{g} / \mathrm{L}$ \\
\hline Carbon tetrachloride & WA & & $\mathrm{U}$ & 5 & & 5 & $\mu \mathrm{g} / \mathrm{L}$ \\
\hline Chlorobenzene & WA & & $\mathrm{U}$ & 5 & & 100 & $\mu \mathrm{g} / \mathrm{L}$ \\
\hline Chloroethane & WA & & $U$ & 10 & & NS & $\mu \mathrm{g} / \mathrm{L}$ \\
\hline Chloroform & WA & & $\mathrm{U}$ & 5 & & 100 & $\mu \mathrm{g} / \mathrm{L}$ \\
\hline Chloroprene & WA & & $\mathrm{U}$ & 20 & & NS & $\mu \mathrm{g} / \mathrm{L}$ \\
\hline cis-1,3-Dichloropropene & WA & & $\mathrm{U}$ & 5 & & NS & $\mu \mathrm{g} / \mathrm{L}$ \\
\hline Dibromochloromethane & WA & & $\mathrm{U}$ & 5 & & NS & $\mu \mathrm{g} / \mathrm{L}$ \\
\hline Dichlorodifluoromethane & WA & & $\mathrm{U}$ & 10 & & NS & $\mu \mathrm{g} / \mathrm{L}$ \\
\hline Ethylbenzene & WA & & $\mathrm{J}$ & 3.67 & & 700 & $\mu \mathrm{g} / \mathrm{L}$ \\
\hline Isobutyl alcohol & WA & & $\mathrm{U}$ & 20 & & NS & $\mu \mathrm{g} / \mathrm{L}$ \\
\hline Methacrylonitrile & WA & & $\mathrm{U}$ & 20 & & NS & $\mu \mathrm{g} / \mathrm{L}$ \\
\hline Methyl bromide & WA & & $\mathrm{U}$ & 10 & & NS & $\mu \mathrm{g} / \mathrm{L}$ \\
\hline Methyl chloride & WA & & $\mathbf{J}$ & 3.33 & & NS & $\mu \mathrm{g} / \mathrm{L}$ \\
\hline Methyl ethyl ketone & WA & & $\mathrm{U}$ & 10 & & NS & $\mu \mathrm{g} / \mathrm{L}$ \\
\hline Methyl iodide & WA & & $\mathrm{U}$ & 10 & & NS & $\mu g / L$ \\
\hline Methylene bromide & WA & & $\mathrm{U}$ & 10 & & NS & $\mu \mathrm{g} / \mathrm{L}$ \\
\hline Methylene chloride & WA & & $\mathrm{U}$ & 5 & & 5 & $\mu \mathrm{g} / \mathrm{L}$ \\
\hline
\end{tabular}


BGS003 (cont'd)

\begin{tabular}{|c|c|c|c|c|c|c|c|c|}
\hline Analyte & Lab & Rep & Avg & Qualifier & Result & Acc & Standard & Units \\
\hline Propionitrile & WA & & & $\bar{U}$ & 50 & & NS & $\mu \mathrm{g} / \mathrm{L}$ \\
\hline Styrene & WA & & & U & 5 & & 100 & $\mu \mathrm{g} / \mathrm{L}$ \\
\hline Tetrachloroethylene & WA & & & $\mathrm{U}$ & 5 & & 5 & $\mu \mathrm{g} / \mathrm{L}$ \\
\hline Toluene & WA & & & $\mathrm{U}$ & 5 & & 1000 & $\mu g / L$ \\
\hline trans-1,3-Dichloropropene & WA & & & $\mathrm{U}$ & 5 & & NS & $\mu \mathrm{g} / \mathrm{L}$ \\
\hline trans-1,4-Dichloro-2-butene & WA & & & $\mathrm{U}$ & 100 & & NS & $\mu \mathrm{g} / \mathrm{L}$ \\
\hline Trichloroethylene & WA & & & $\mathrm{U}$ & 5 & & 5 & $\mu \mathrm{g} / \mathrm{L}$ \\
\hline Trichlorofluoromethane & WA & & & $\mathrm{U}$ & 5 & & NS & $\mu \mathrm{g} / \mathrm{L}$ \\
\hline Tritium & EMS & & & & 2.53 & 0.40 & 20 & $\mathrm{pCi} / \mathrm{ml}$ \\
\hline Vinyl acetate & WA & & & U & 10 & & NS & $\mu \mathrm{g} / \mathrm{L}$ \\
\hline Vinyl chloride & WA & & & $\mathrm{U}$ & 10 & & 2 & $\mu \mathrm{g} / \mathrm{L}$ \\
\hline Xylenes (total) & WA & & & $\mathrm{U}$ & 5 & & 10000 & $\mu \mathrm{g} / \mathrm{L}$ \\
\hline
\end{tabular}




\section{BGS003B}

Field Measurements:

Sample Date: 08/25/94

$\mathrm{pH}: 4.52$

Conductivity: $34 \mu \mathrm{S} / \mathrm{cm}$

\begin{tabular}{|c|c|c|c|c|c|c|c|c|}
\hline Analyte & $\mathrm{Lab}$ & Rep & Avg & Qualifier & Result & Acc & Standard & Units \\
\hline 1,1,1,2-Tetrachloroethane & WA & & & $\bar{U}$ & 10 & & NS & $\mu \mathrm{g} / \mathrm{L}$ \\
\hline 1,1,1-Trichloroethane & WA & & & $\mathrm{U}$ & 5 & & 200 & $\mu \mathrm{g} / \mathrm{L}$ \\
\hline 1,1,2,2-Tetrachloroethane & WA & & & $\mathrm{U}$ & 5 & & NS & $\mu \mathrm{g} / \mathrm{L}$ \\
\hline 1,1,2-Trichloroethane & WA & & & $\mathrm{U}$ & 5 & & 5 & $\mu \mathrm{g} / \mathrm{L}$ \\
\hline 1,1-Dichloroethane & WA & & & $\mathrm{U}$ & 5 & & NS & $\mu \mathrm{g} / \mathrm{L}$ \\
\hline 1,1-Dichloroethylene & WA & & & $\mathrm{U}$ & 5 & & 7 & $\mu \mathrm{g} / \mathrm{L}$ \\
\hline 1,2,3-Trichloropropane & WA & & & $\mathrm{U}$ & 10 & & NS & $\mu \mathrm{g} / \mathrm{L}$ \\
\hline 1,2-Dibromo-3-chloropropane & WA & & & $\mathrm{U}$ & 20 & & 0.2 & $\mu \mathrm{g} / \mathrm{L}$ \\
\hline 1,2-Dibromoethane & WA & & & $U$ & 20 & & NS & $\mu \mathrm{g} / \mathrm{L}$ \\
\hline 1,2-Dichloroethane & WA & & & $\mathrm{U}$ & 5 & & 5 & $\mu \mathrm{g} / \mathrm{L}$ \\
\hline 1,2-Dichloroethylene (total) & WA & & & $\mathrm{U}$ & 5 & & 70 & $\mu \mathrm{g} / \mathrm{L}$ \\
\hline 1,2-Dichloropropane & WA & & & $\mathrm{U}$ & 5 & & 5 & $\mu \mathrm{g} / \mathrm{L}$ \\
\hline 2-Hexanone & WA & & & $\mathrm{U}$ & 10 & & NS & $\mu \mathrm{g} / \mathrm{L}$ \\
\hline 4-Methyl-2-pentanone & WA & & & $\mathrm{U}$ & 10 & & NS & $\mu \mathrm{g} / \mathrm{L}$ \\
\hline Acetone & WA & & & JV & 5.49 & & NS & $\mu \mathrm{g} / \mathrm{L}$ \\
\hline Acetonitrile (Methyl cyanide) & WA & & & $U$ & 20 & & NS & $\mu \mathrm{g} / \mathrm{L}$ \\
\hline Acrolein & WA & & & $\mathrm{U}$ & 10 & & NS & $\mu \mathrm{g} / \mathrm{L}$ \\
\hline Acrylonitrile & WA & & & $\mathrm{U}$ & 10 & & NS & $\mu \mathrm{g} / \mathrm{L}$ \\
\hline Allyl chloride & WA & & & $\mathrm{U}$ & 100 & & NS & $\mu \mathrm{g} / \mathrm{L}$ \\
\hline Benzene & WA & & & $\mathbf{U}$ & 5 & & 5 & $\mu \mathrm{g} / \mathrm{L}$ \\
\hline Bromodichloromethane & WA & & & $\mathrm{U}$ & 5 & & NS & $\mu \mathrm{g} / \mathrm{L}$ \\
\hline Bromoform & WA & & & $\mathrm{U}$ & 5 & & NS & $\mu \mathrm{g} / \mathrm{L}$ \\
\hline Carbon disulfide & WA & & & $\mathrm{U}$ & 5 & & NS & $\mu \mathrm{g} / \mathrm{L}$ \\
\hline Carbon tetrachloride & WA & & & $\mathrm{U}$ & 5 & & 5 & $\mu \mathrm{g} / \mathrm{L}$ \\
\hline Chlorobenzene & WA & & & $\mathrm{U}$ & 5 & & 100 & $\mu \mathrm{g} / \mathrm{L}$ \\
\hline Chloroethane & WA & & & $\mathrm{U}$ & 10 & & NS & $\mu \mathrm{g} / \mathrm{L}$ \\
\hline Chloroform & WA & & & $\mathrm{U}$ & 5 & & 100 & $\mu \mathrm{g} / \mathrm{L}$ \\
\hline Chloroprene & WA & & & $\mathrm{U}$ & 20 & & NS & $\mu \mathrm{g} / \mathrm{L}$ \\
\hline cis-1,3-Dichloropropene & WA & & & $\mathrm{U}$ & 5 & & NS & $\mu \mathrm{g} / \mathrm{L}$ \\
\hline Dibromochloromethane & WA & & & $\mathrm{U}$ & 5 & & NS & $\mu \mathrm{g} / \mathrm{L}$ \\
\hline Dichlorodifluoromethane & WA & & & $\mathrm{U}$ & 10 & & NS & $\mu \mathrm{g} / \mathrm{L}$ \\
\hline Ethylbenzene & WA & & & $U$ & 5 & & 700 & $\mu \mathrm{g} / \mathrm{L}$ \\
\hline Isobutyl alcohol & WA & & & $\mathrm{U}$ & 20 & & NS & $\mu \mathrm{g} / \mathrm{L}$ \\
\hline Methacrylonitrile & WA & & & $\mathbf{U}$ & 20 & & NS & $\mu \mathrm{g} / \mathrm{L}$ \\
\hline Methyl bromide & WA & & & $\mathrm{U}$ & 10 & & NS & $\mu \mathrm{g} / \mathrm{L}$ \\
\hline Methyl chloride & WA & & & $\mathrm{J}$ & 2.2 & & NS & $\mu \mathrm{g} / \mathrm{L}$ \\
\hline Methyl ethyl ketone & WA & & & $\mathrm{U}$ & 10 & & NS & $\mu \mathrm{g} / \mathrm{L}$ \\
\hline Methyl iodide & WA & & & $\mathrm{U}$ & 10 & & NS & $\mu \mathrm{g} / \mathrm{L}$ \\
\hline Methylene bromide & WA & & & $\mathrm{U}$ & 10 & & NS & $\mu \mathrm{g} / \mathrm{L}$ \\
\hline Methylene chloride & WA & & & $\mathrm{U}$ & 5 & & 5 & $\mu \mathrm{g} / \mathrm{L}$ \\
\hline Propionitrile & WA & & & $\mathrm{U}$ & 50 & & NS & $\mu \mathrm{g} / \mathrm{L}$ \\
\hline
\end{tabular}


BGS003B (cont'd)

\begin{tabular}{|c|c|c|c|c|c|c|c|c|}
\hline Analyte & Lab & $\operatorname{Rep}$ & Avg & Qualifier & Result & Acc & Standard & Units \\
\hline$\overline{\text { Styrene }}$ & WA & & & $\mathrm{U}$ & 5 & & 100 & $\mu \mathrm{g} / \mathrm{L}$ \\
\hline Tetrachloroethylene & WA & & & $\mathrm{U}$ & 5 & & 5 & $\mu \mathrm{g} / \mathrm{L}$ \\
\hline Toluene & WA & & & $\mathrm{U}$ & 5 & & 1000 & $\mu \mathrm{g} / \mathrm{L}$ \\
\hline trans-1,3-Dichloropropene & WA & & & $\mathrm{U}$ & 5 & & NS & $\mu \mathrm{g} / \mathrm{L}$ \\
\hline trans-1,4-Dichloro-2-butene & WA & & & $\mathrm{U}$ & 100 & & NS & $\mu \mathrm{g} / \mathrm{L}$ \\
\hline Trichloroethylene & WA & & & $\mathrm{U}$ & 5 & & 5 & $\mu \mathrm{g} / \mathrm{L}$ \\
\hline Trichlorofluoromethane & WA & & & $\mathrm{U}$ & 5 & & NS & $\mu \mathrm{g} / \mathrm{L}$ \\
\hline Tritium & EMS & & & & 2.69 & 0.41 & 20 & $\mathrm{pCi} / \mathrm{ml}$ \\
\hline Vinyl acetate & WA & & & $\mathrm{U}$ & 10 & & NS & $\mu \mathrm{g} / \mathrm{L}$ \\
\hline Vinyl chloride & WA & & & $\mathrm{U}$ & 10 & & 2 & $\mu \mathrm{g} / \mathrm{L}$ \\
\hline Xylenes (total) & WA & & & $U$ & 5 & & 10000 & $\mu \mathrm{g} / \mathrm{L}$ \\
\hline
\end{tabular}




\section{FHB013}

Field Measurements:

Sample Date: 08/25/94

Depth to Water: $3.05 \mathrm{ft}$ below TOC

Water Level Elevation: $211 \mathrm{msl}$

pH: 5.31

Conductivity: $44 \mu \mathrm{S} / \mathrm{cm}$

\begin{tabular}{|c|c|c|c|c|c|c|c|}
\hline Analyte & Lab & $\operatorname{Rep}$ & Qualifier & Result & Acc & Standard & Units \\
\hline 1,1,1,2-Tetrachloroethane & WA & & $\overline{\mathrm{U}}$ & 10 & & NS & $\mu \mathrm{g} / \mathrm{L}$ \\
\hline 1,1,1-Trichloroethane & ADS & & U & 50 & & 200 & $\mu \mathrm{g} / \mathrm{L}$ \\
\hline 1,1,1-Trichloroethane & WA & & $\mathrm{U}$ & 5 & & 200 & $\mu \mathrm{g} / \mathrm{L}$ \\
\hline 1,1,2,2-Tetrachloroethane & ADS & & U & 50 & & NS & $\mu \mathrm{g} / \mathrm{L}$ \\
\hline 1,1,2,2-Tetrachloroethane & WA & & $\mathrm{U}$ & 5 & & NS & $\mu \mathrm{g} / \mathrm{L}$ \\
\hline 1,1,2-Trichloroethane & $\mathrm{ADS}$ & & U & 50 & & 5 & $\mu \mathrm{g} / \mathrm{L}$ \\
\hline 1,1,2-Trichloroethane & WA & & $\mathrm{U}$ & 5 & & 5 & $\mu \mathrm{g} / \mathrm{L}$ \\
\hline 1,1-Dichloroethane & ADS & & U & 50 & & NS & $\mu \mathrm{g} / \mathrm{L}$ \\
\hline 1,1-Dichloroethane & WA & & U & 5 & & NS & $\mu \mathrm{g} / \mathrm{L}$ \\
\hline 1,1-Dichloroethene & ADS & & $\mathrm{U}$ & 50 & & 5 & $\mu \mathrm{g} / \mathrm{L}$ \\
\hline 1,1-Dichloroethylene & WA & & $\mathrm{U}$ & 5 & & 7 & $\mu \mathrm{g} / \mathrm{L}$ \\
\hline 1,2,3-Trichloropropane & WA & & $\mathrm{U}$ & 10 & & NS & $\mu \mathrm{g} / \mathrm{L}$ \\
\hline 1,2-Dibromo-3-chloropropane & WA & & $\mathrm{U}$ & 20 & & 0.2 & $\mu \mathrm{g} \Omega$ \\
\hline 1,2-Dibromoethane & WA & & $\mathrm{U}$ & 20 & & NS & $\mu \mathrm{g} / \mathrm{L}$ \\
\hline 1,2-Dichloroethane & ADS & & U & 50 & & 5 & $\mu \mathrm{g} / \mathrm{L}$ \\
\hline 1,2-Dichloroethane & WA & & $\mathrm{U}$ & 5 & & 5 & $\mu \mathrm{g} / \mathrm{L}$ \\
\hline 1,2-Dichloroethylene (total) & WA & & & 42.3 & & 70 & $\mu g / L$ \\
\hline 1,2-Dichloropropane & ADS & & $\mathrm{U}$ & 50 & & NS & $\mu \mathrm{g} / \mathrm{L}$ \\
\hline 1,2-Dichloropropane & WA & & $\mathrm{U}$ & 5 & & 5 & $\mu \mathrm{g} / \mathrm{L}$ \\
\hline 2-Butanone & $\mathrm{ADS}$ & & $\mathrm{U}$ & 50 & & NS & $\mu \mathrm{g} / \mathrm{L}$ \\
\hline 2-Hexanone & ADS & & $\mathrm{U}$ & 50 & & NS & $\mu \mathrm{g} / \mathrm{L}$ \\
\hline 2-Hexanone & WA & & $\mathrm{U}$ & 10 & & NS & $\mu \mathrm{g} / \mathrm{L}$ \\
\hline 4-Methyl-2-Pentanone & ADS & & $\mathrm{U}$ & 50 & & NS & $\mu \mathrm{g} / \mathrm{L}$ \\
\hline 4-Methyl-2-pentanone & WA & & $\mathrm{U}$ & 10 & & NS & $\mu \mathrm{g} / \mathrm{L}$ \\
\hline Acetone & ADS & & $\mathrm{U}$ & 50 & & NS & $\mu \mathrm{g} / \mathrm{L}$ \\
\hline Acetone & WA & & $\mathrm{U}$ & 10 & & NS & $\mu \mathrm{g} / \mathrm{L}$ \\
\hline Acetonitrile (Methyl cyanide) & WA & & $\mathrm{U}$ & 20 & & NS & $\mu \mathrm{g} / \mathrm{L}$ \\
\hline Acrolein & WA & & $\mathrm{U}$ & 10 & & NS & $\mu \mathrm{g} / \mathrm{L}$ \\
\hline Acrylonitrile & WA & & $\mathrm{U}$ & 10 & & NS & $\mu \mathrm{g} / \mathrm{L}$ \\
\hline Allyl chloride & WA & & $\mathrm{U}$ & 100 & & NS & $\mu \mathrm{g} / \mathrm{L}$ \\
\hline Benzene & ADS & & $\mathrm{J}$ & 2 & & 5 & $\mu \mathrm{g} / \mathrm{L}$ \\
\hline Benzene & WA & & $\mathrm{U}$ & 5 & & 5 & $\mu \mathrm{g} / \mathrm{L}$ \\
\hline Bromodichloromethane & $\mathrm{ADS}$ & & $\mathbf{U}$ & 50 & & NS & $\mu \mathrm{g} / \mathrm{L}$ \\
\hline Bromodichloromethane & WA & & $\mathrm{U}$ & 5 & & NS & $\mu \mathrm{g} / \mathrm{L}$ \\
\hline Bromoform & ADS & & $\mathrm{U}$ & 50 & & NS & $\mu \mathrm{g} / \mathrm{L}$ \\
\hline Bromoform & WA & & $\mathrm{U}$ & 5 & & NS & $\mu \mathrm{g} / \mathrm{L}$ \\
\hline Bromomethane & ADS & & $\mathrm{J}$ & 7 & & NS & $\mu \mathrm{g} / \mathrm{L}$ \\
\hline Carbon Disulfide & ADS & & $\mathbf{J}$ & 2 & & NS & $\mu \mathrm{g} / \mathrm{L}$ \\
\hline Carbon disulfide & WA & & $\mathrm{U}$ & 5 & & NS & $\mu \mathrm{g} / \mathrm{L}$ \\
\hline Carbon Tetrachloride & ADS & & J & 2 & & 5 & $\mu \mathrm{g} / \mathrm{L}$ \\
\hline Carbon tetrachloride & WA & & $\mathrm{U}$ & 5 & & 5 & $\mu \mathrm{g} / \mathrm{L}$ \\
\hline
\end{tabular}


FHB013 (cont'd)

\begin{tabular}{|c|c|c|c|c|c|c|c|}
\hline Analyte & Lab & Rep & Qualifier & Result & Acc & Standard & Units \\
\hline Chlorobenzene & ADS & & $\bar{U}$ & 50 & & 100 & $\mu \mathrm{g} / \mathrm{L}$ \\
\hline Chlorobenzene & WA & & $\mathrm{U}$ & 5 & & 100 . & $\mu \mathrm{g} / \mathrm{L}$ \\
\hline Chloroethane & ADS & & $\mathrm{U}$ & 50 & & NS & $\mu \mathrm{g} / \mathrm{L}$ \\
\hline Chloroethane & WA & & $\mathrm{U}$ & 10 & & NS & $\mu \mathrm{g} / \mathrm{L}$ \\
\hline Chloroform & ADS & & $\mathbf{J}$ & 3 & & 100 & $\mu \mathrm{g} / \mathrm{L}$ \\
\hline Chloroform & WA & & J & 1.63 & & 100 & $\mu \mathrm{g} / \mathrm{L}$ \\
\hline Chloromethane & $\mathrm{ADS}$ & & U & 50 & & NS & $\mu \mathrm{g} / \mathrm{L}$ \\
\hline Chloroprene & WA & & $\mathrm{U}$ & 20 & & NS & $\mu \mathrm{g} / \mathrm{L}$ \\
\hline cis-1,2-Dichloroethene & ADS & & & 74 & & 70 & $\mu \mathrm{g} / \mathrm{L}$ \\
\hline cis-1,3-Dichloropropene & $\mathrm{ADS}$ & & U & 50 & & NS & $\mu \mathrm{g} / \mathrm{L}$ \\
\hline cis-1,3-Dichloropropene & WA & & $\mathrm{U}$ & 5 & & NS & $\mu \mathrm{g} / \mathrm{L}$ \\
\hline Dibromochloromethane & ADS & & $\mathrm{U}$ & 50 & & NS & $\mu \mathrm{g} / \mathrm{L}$ \\
\hline Dibromochloromethane & WA & & $\mathrm{U}$ & 5 & & NS & $\mu \mathrm{g} / \mathrm{L}$ \\
\hline Dichlorodifluoromethane & WA & & J & 1.38 & & NS & $\mu \mathrm{g} / \mathrm{L}$ \\
\hline Ethylbenzene & ADS & & U & 50 & & 700 & $\mu \mathrm{g} / \mathrm{L}$ \\
\hline Ethylbenzene & WA & & $\mathrm{U}$ & 5 & & 700 & $\mu \mathrm{g} / \mathrm{L}$ \\
\hline Isobutyl alcohol & WA & & U & 20 & & NS & $\mu \mathrm{g} / \mathrm{L}$ \\
\hline Methacrylonitrile & WA & & $\mathrm{U}$ & 20 & & NS & $\mu \mathrm{g} / \mathrm{L}$ \\
\hline Methyl bromide & WA & & $\mathrm{U}$ & 10 & & NS & $\mu \mathrm{g} / \mathrm{L}$ \\
\hline Methyl chloride & WA & & U & 10 & & NS & $\mu \mathrm{g} / \mathrm{L}$ \\
\hline Methyl ethyl ketone & WA & & U & 10 & & NS & $\mu \mathrm{g} / \mathrm{L}$ \\
\hline Methyl iodide & WA & & $\mathbf{U}$ & 10 & & NS & $\mu \mathrm{g} / \mathrm{L}$ \\
\hline Methylene bromide & WA & & $\mathrm{U}$ & 10 & & NS & $\mu \mathrm{g} / \mathrm{L}$ \\
\hline Methylene Chloride & ADS & & $\mathrm{U}$ & 50 & & 5 & $\mu \mathrm{g} / \mathrm{L}$ \\
\hline Methylene chloride & WA & & $\mathrm{U}$ & 5 & & 5 & $\mu \mathrm{g} / \mathrm{L}$ \\
\hline Propionitrile & WA & & $\mathrm{U}$ & 50 & & NS & $\mu \mathrm{g} / \mathrm{L}$ \\
\hline Styrene & ADS & & U & 50 & & 100 & $\mu \mathrm{g} / \mathrm{L}$ \\
\hline Styrene & WA & & U & 5 & & 100 & $\mu \mathrm{g} / \mathrm{L}$ \\
\hline Tetrachloroethene & ADS & & $\mathrm{J}$ & 13 & & 5 & $\mu \mathrm{g} / \mathrm{L}$ \\
\hline Tetrachloroethylene & WA & & & 5.94 & & 5 & $\mu \mathrm{g} / \mathrm{L}$ \\
\hline Toluene & ADS & & U & 50 & & 1000 & $\mu \mathrm{g} / \mathrm{L}$ \\
\hline Toluene & WA & & U & 5 & & 1000 & $\mu \mathrm{g} / \mathrm{L}$ \\
\hline trans-1,2-Dichloroethene & ADS & & $\mathrm{U}$ & 50 & & 100 & $\mu \mathrm{g} / \mathrm{L}$ \\
\hline trans-1,3-Dichloropropene & ADS & & U & 50 & & NS & $\mu \mathrm{g} / \mathrm{L}$ \\
\hline trans-1,3-Dichloropropene & WA & & U & 5 & & NS & $\mu \mathrm{g} / \mathrm{L}$ \\
\hline trans-1,4-Dichloro-2-butene & WA & & $\mathrm{U}$ & 100 & & NS & $\mu \mathrm{g} / \mathrm{L}$ \\
\hline Trichloroethene & ADS & & $J$ & 41 & & 5 & $\mu \mathrm{g} / \mathrm{L}$ \\
\hline Trichloroethylene & WA & & & 29.7 & & 5 & $\mu \mathrm{g} / \mathrm{L}$ \\
\hline Trichlorofluoromethane & WA & & $\mathrm{U}$ & 5 & & NS & $\mu \mathrm{g} / \mathrm{L}$ \\
\hline Tritium & EMS & & & 16700 & 180 & 20 & $\mathrm{pCi} / \mathrm{ml}$ \\
\hline Vinyl Acetate & $\mathrm{ADS}$ & & U & 50 & & NS & $\mu \mathrm{g} / \mathrm{L}$ \\
\hline Vinyl acetate & WA & & $\mathrm{U}$ & 10 & & NS & $\mu \mathrm{g} / \mathrm{L}$ \\
\hline Vinyl Chloride & ADS & & $\mathrm{U}$ & 50 & & 2 & $\mu g / L$ \\
\hline Vinyl chloride & WA & & U & 10 & & 2 & $\mu \mathrm{g} / \mathrm{L}$ \\
\hline Xylenes (total) & WA & & U & 5 & & 10000 & $\mu \mathrm{g} / \mathrm{L}$ \\
\hline Xylenes (total) 1 & ADS & & $\mathrm{U}$ & 100 & & 10000 & $\mu \mathrm{g} / \mathrm{L}$ \\
\hline
\end{tabular}

${ }^{1}$ ADS analyzes xylenes as m-Xylene and otho+para-Xylenes and reports them separately. The result reported is the sum of the two analytes. 


\section{FHB013B}

Field Measurements:

Sample Date: 08/25/94

pH: 5.15

Conductivity: $45 \mu \mathrm{S} / \mathrm{cm}$

\begin{tabular}{|c|c|c|c|c|c|c|c|c|}
\hline Analyte & Lab & Rep & Avg & Qualifier & Result & Acc & Standard & Units \\
\hline 1,1,1,2-Tetrachloroethane & WA & & & $\bar{U}$ & 10 & & NS & $\mu \mathrm{g} / \mathrm{L}$ \\
\hline 1,1,1-Trichloroethane & WA & & & $U$ & 5 & & 200 & $\mu \mathrm{g} / \mathrm{L}$ \\
\hline 1,1,2,2-Tetrachloroethane & WA & & & $\mathrm{U}$ & 5 & & NS & $\mu \mathrm{g} / \mathrm{L}$ \\
\hline 1,1,2-Trichloroethane & WA & & & $U$ & 5 & & 5 & $\mu \mathrm{g} / \mathrm{L}$ \\
\hline 1,1-Dichloroethane & WA & & & $\mathrm{U}$ & 5 & & NS & $\mu \mathrm{g} / \mathrm{L}$ \\
\hline 1,1-Dichloroethylene & WA & & & $\mathrm{U}$ & 5 & & 7 & $\mu \mathrm{g} / \mathrm{L}$ \\
\hline 1,2,3-Trichloropropane & WA & & & $\mathrm{U}$ & 10 & & NS & $\mu \mathrm{g} / \mathrm{L}$ \\
\hline 1,2-Dibromo-3-chloropropane & WA & & & $\mathrm{U}$ & 20 & & 0.2 & $\mu \mathrm{g} / \mathrm{L}$ \\
\hline 1,2-Dibromoethane & WA & & & $U$ & 20 & & NS & $\mu \mathrm{g} / \mathrm{L}$ \\
\hline 1,2-Dichloroethane & WA & & & $\mathrm{U}$ & 5 & & 5 & $\mu \mathrm{g} / \mathrm{L}$ \\
\hline 1,2-Dichloroethylene (total) & WA & & & & 36.7 & & 70 & $\mu \mathrm{g} / \mathrm{L}$ \\
\hline 1,2-Dichloropropane & WA & & & $\mathrm{U}$ & 5 & & 5 & $\mu \mathrm{g} / \mathrm{L}$ \\
\hline 2-Hexanone & WA & & & $\mathrm{U}$ & 10 & & NS & $\mu \mathrm{g} / \mathrm{L}$ \\
\hline 4-Methyl-2-pentanone & WA & & & $\mathrm{U}$ & 10 & & NS & $\mu \mathrm{g} / \mathrm{L}$ \\
\hline Acetone & WA & & & V & 13.3 & & NS & $\mu \mathrm{g} / \mathrm{L}$ \\
\hline Acetonitrile (Methyl cyanide) & WA & & & $\mathrm{U}$ & 20 & & NS & $\mu \mathrm{g} / \mathrm{L}$ \\
\hline Acrolein & WA & & & $\mathrm{U}$ & 10 & & NS & $\mu \mathrm{g} / \mathrm{L}$ \\
\hline Acrylonitrile & WA & & & $\mathrm{U}$ & 10 & & NS & $\mu \mathrm{g} / \mathrm{L}$ \\
\hline Allyl chloride & WA & & & $\mathrm{U}$ & 100 & & NS & $\mu \mathrm{g} / \mathrm{L}$ \\
\hline Benzene & WA & & & $\mathrm{U}$ & 5 & & 5 & $\mu \mathrm{g} / \mathrm{L}$ \\
\hline Bromodichloromethane & WA & & & $\mathrm{U}$ & 5 & & NS & $\mu \mathrm{g} / \mathrm{L}$ \\
\hline Bromoform & WA & & & $\mathrm{U}$ & 5 & & NS & $\mu \mathrm{g} / \mathrm{L}$ \\
\hline Carbon disulfide & WA & & & $\mathrm{U}$ & 5 & & NS & $\mu \mathrm{g} / \mathrm{L}$ \\
\hline Carbon tetrachloride & WA & & & $\mathrm{U}$ & 5 & & 5 & $\mu \mathrm{g} / \mathrm{L}$ \\
\hline Chlorobenzene & WA & & & $\mathrm{U}$ & 5 & & 100 & $\mu \mathrm{g} / \mathrm{L}$ \\
\hline Chloroethane & WA & & & $\mathrm{U}$ & 10 & & NS & $\mu \mathrm{g} / \mathrm{L}$ \\
\hline Chloroform & WA & & & $\mathrm{U}$ & 5 & & 100 & $\mu \mathrm{g} / \mathrm{L}$ \\
\hline Chloroprene & WA & & & $U$ & 20 & & NS & $\mu \mathrm{g} / \mathrm{L}$ \\
\hline cis-1,3-Dichloropropene & WA & & & $\mathrm{U}$ & 5 & & NS & $\mu g / L$ \\
\hline Dibromochloromethane & WA & & & $\mathrm{U}$ & 5 & & NS & $\mu \mathrm{g} / \mathrm{L}$ \\
\hline Dichlorodifluoromethane & WA & & & $\mathrm{U}$ & 10 & & NS & $\mu \mathrm{g} / \mathrm{L}$ \\
\hline Ethylbenzene & WA & & & $\mathrm{U}$ & 5 & & 700 & $\mu \mathrm{g} / \mathrm{L}$ \\
\hline Isobutyl alcohol & WA & & & $\mathrm{U}$ & 20 & & NS & $\mu \mathrm{g} / \mathrm{L}$ \\
\hline Methacrylonitrile & WA & & & $\mathrm{U}$ & 20 & & NS & $\mu \mathrm{g} / \mathrm{L}$ \\
\hline Methyl bromide & WA & & & $\mathbf{U}$ & 10 & & NS & $\mu \mathrm{g} / \mathrm{L}$ \\
\hline Methyl chloride & WA & & & $\mathrm{U}$ & 10 & & NS & $\mu \mathrm{g} / \mathrm{L}$ \\
\hline Methyl ethyl ketone & WA & & & $\mathrm{U}$ & 10 & & NS & $\mu \mathrm{g} / \mathrm{L}$ \\
\hline Methyl iodide & WA & & & $\mathrm{U}$ & 10 & & NS & $\mu \mathrm{g} / \mathrm{L}$ \\
\hline Methylene bromide & WA & & & $U$ & 10 & & NS & $\mu \mathrm{g} / \mathrm{L}$ \\
\hline Methylene chloride & WA & & & $\mathbf{U}$ & 5 & & 5 & $\mu \mathrm{g} / \mathrm{L}$ \\
\hline Propionitrile & WA & & & $\underline{U}$ & 50 & & NS & $\mu \mathrm{g} / \mathrm{L}$ \\
\hline
\end{tabular}


FHB013B (cont'd)

\begin{tabular}{|c|c|c|c|c|c|c|c|c|}
\hline Analyte & Lab & Rep & Avg & Qualifier & Result & Acc & Standard & Units \\
\hline$\overline{\text { Styrene }}$ & WA & & & $\bar{U}$ & 5 & & 100 & $\mu \mathrm{g} / \mathrm{L}$ \\
\hline Tetrachloroethylene & WA & & & $U$ & 5 & & 5 & $\mu \mathrm{g} / \mathrm{L}$ \\
\hline Toluene & WA & & & $\mathrm{J}$ & 1.33 & & 1000 & $\mu \mathrm{g} / \mathrm{L}$ \\
\hline trans-1,3-Dichloropropene & WA & & & $\mathrm{U}$ & 5 & & NS & $\mu \mathrm{g} / \mathrm{L}$ \\
\hline trans-1,4-Dichloro-2-butene & WA & & & $\mathrm{U}$ & 100 & & NS & $\mu \mathrm{g} / \mathrm{L}$ \\
\hline Trichloroethylene & WA & & & $J$ & 3.01 & & 5 & $\mu \mathrm{g} / \mathrm{L}$ \\
\hline Trichlorofluoromethane & WA & & & $\mathrm{U}$ & 5 & & NS & $\mu \mathrm{g} / \mathrm{L}$ \\
\hline Tritium & EMS & & & & 13500 & 125 & 20 & $\mathrm{pCi} / \mathrm{ml}$ \\
\hline Vinyl acetate & WA & & & $\mathbf{U}$ & 10 & & NS & $\mu \mathrm{g} / \mathrm{L}$ \\
\hline Vinyl chloride & WA & & & $\mathrm{U}$ & 10 & & 2 & $\mu g / L$ \\
\hline Xylenes (total) & WA & & & $\mathrm{U}$ & 5 & & 10000 & $\mu \mathrm{g} / \mathrm{L}$ \\
\hline
\end{tabular}




\section{FHB014}

Field Measurements:

Sample Date: 08/25/94

Depth to Water: $3.8 \mathrm{ft}$ below TOC

Water Level Elevation: $211 \mathrm{msl}$

pH: 5.4

Conductivity: $38 \mu \mathrm{S} / \mathrm{cm}$

\begin{tabular}{|c|c|c|c|c|c|c|c|c|}
\hline Analyte & $\mathrm{Lab}$ & $\operatorname{Rep}$ & Avg & Qualifier & Result & Acc & Standard & Units \\
\hline 1,1,1,2-Tetrachloroethane & WA & & & $\overline{\mathrm{U}}$ & 10 & & NS & $\mu \mathrm{g} / \mathrm{L}$ \\
\hline 1,1,1,2-Tetrachloroethane & WA & $\mathbf{R}$ & & $\mathrm{U}$ & 10 & & NS & $\mu \mathrm{g} / \mathrm{L}$ \\
\hline 1,1,1-Trichloroethane & WA & & & $\mathrm{U}$ & 5 & & 200 & $\mu \mathrm{g} / \mathrm{L}$ \\
\hline 1,1,1-Trichloroethane & WA & $\mathbf{R}$ & & $\mathrm{U}$ & 5 & & 200 & $\mu \mathrm{g} / \mathrm{L}$ \\
\hline 1,1,2,2-Tetrachloroethane & WA & & & $\mathbf{U}$ & 5 & & NS & $\mu \mathrm{g} / \mathrm{L}$ \\
\hline 1,1,2,2-Tetrachloroethane & WA & $\mathbf{R}$ & & $\mathrm{U}$ & 5 & & NS & $\mu g / L$ \\
\hline 1,1,2-Trichloroethane & WA & & & $\mathrm{U}$ & 5 & & 5 & $\mu \mathrm{g} / \mathrm{L}$ \\
\hline 1,1,2-Trichloroethane & WA & $\mathbf{R}$ & & $\mathbf{U}$ & 5 & & 5 & $\mu \mathrm{g} / \mathrm{L}$ \\
\hline 1,1-Dichloroethane & WA & & & $\mathrm{U}$ & 5 & & NS & $\mu \mathrm{g} / \mathrm{L}$ \\
\hline 1,1-Dichloroethane & WA & $\mathbf{R}$ & & $\mathrm{U}$ & 5 & & NS & $\mu \mathrm{g} / \mathrm{L}$ \\
\hline 1,1-Dichloroethylene & WA & & & $\mathrm{U}$ & 5 & & 7 & $\mu \mathrm{g} / \mathrm{L}$ \\
\hline 1,1-Dichloroethylene & WA & $\mathbf{R}$ & & $\mathrm{U}$ & 5 & & 7 & $\mu \mathrm{g} / \mathrm{L}$ \\
\hline 1,2,3-Trichloropropane & WA & & & $\mathrm{U}$ & 10 & & NS & $\mu g / L$ \\
\hline 1,2,3-Trichloropropane & WA & $\mathbf{R}$ & & $\mathrm{U}$ & 10 & & NS & $\mu \mathrm{g} / \mathrm{L}$ \\
\hline 1,2-Dibromo-3-chloropropane & WA & & & $\mathbf{U}$ & 20 & & 0.2 & $\mu \mathrm{g} / \mathrm{L}$ \\
\hline 1,2-Dibromo-3-chloropropane & WA & $\mathbf{R}$ & & $\mathrm{U}$ & 20 & & 0.2 & $\mu \mathrm{g} / \mathrm{L}$ \\
\hline 1,2-Dibromoethane & WA & & & $\mathrm{U}$ & 20 & & NS & $\mu \mathrm{g} / \mathrm{L}$ \\
\hline 1,2-Dibromoethane & WA & $\mathbf{R}$ & & $\mathrm{U}$ & 20 & & NS & $\mu \mathrm{g} / \mathrm{L}$ \\
\hline 1,2-Dichloroethane & WA & & & $\mathrm{U}$ & 5 & & 5 & $\mu \mathrm{g} / \mathrm{L}$ \\
\hline 1,2-Dichloroethane & WA & $\mathbf{R}$ & & $\mathrm{U}$ & 5 & & 5 & $\mu \mathrm{g} / \mathrm{L}$ \\
\hline 1,2-Dichloroethylene (total) & WA & & & & 25.3 & & 70 & $\mu \mathrm{g} / \mathrm{L}$ \\
\hline 1,2-Dichloroethylene (total) & WA & $\mathrm{R}$ & & & 25.4 & & 70 & $\mu \mathrm{g} / \mathrm{L}$ \\
\hline 1,2-Dichloropropane & WA & & & $\mathrm{U}$ & 5 & & 5 & $\mu \mathrm{g} / \mathrm{L}$ \\
\hline 1,2-Dichloropropane & WA & $\mathbf{R}$ & & $\mathrm{U}$ & 5 & & 5 & $\mu \mathrm{g} / \mathrm{L}$ \\
\hline 2-Hexanone & WA & & & $\mathrm{U}$ & 10 & & NS & $\mu \mathrm{g} / \mathrm{L}$ \\
\hline 2-Hexanone & WA & $\mathbf{R}$ & & $\mathrm{U}$ & 10 & & NS & $\mu \mathrm{g} / \mathrm{L}$ \\
\hline 4-Methyl-2-pentanone & WA & & & $\mathrm{U}$ & 10 & & NS & $\mu \mathrm{g} / \mathrm{L}$ \\
\hline 4-Methyl-2-pentanone & WA & $\mathbf{R}$ & & $\mathrm{U}$ & 10 & & NS & $\mu \mathrm{g} / \mathrm{L}$ \\
\hline Acetone & WA & & & $\mathrm{U}$ & 10 & & NS & $\mu \mathrm{g} / \mathrm{L}$ \\
\hline Acetone & WA & $\mathrm{R}$ & & $\mathrm{N}$ & 7.05 & & NS & $\mu \mathrm{g} / \mathrm{L}$ \\
\hline Acetonitrile (Methyl cyanide) & WA & & & $\mathrm{U}$ & 20 & & NS & $\mu \mathrm{g} / \mathrm{L}$ \\
\hline Acetonitrile (Methyl cyanide) & WA & $\mathbf{R}$ & & $\mathrm{U}$ & 20 & & NS & $\mu \mathrm{g} / \mathrm{L}$ \\
\hline Acrolein & WA & & & $\mathrm{U}$ & 10 & & NS & $\mu \mathrm{g} / \mathrm{L}$ \\
\hline Acrolein & WA & $\mathbf{R}$ & & $\mathrm{U}$ & 10 & & NS & $\mu \mathrm{g} / \mathrm{L}$ \\
\hline Acrylonitrile & WA & & & $\mathrm{U}$ & 10 & & NS & $\mu \mathrm{g} / \mathrm{L}$ \\
\hline Acrylonitrile & WA & $\mathbf{R}$ & & $\mathrm{U}$ & 10 & & NS & $\mu \mathrm{g} / \mathrm{L}$ \\
\hline Allyl chloride & WA & & & $\mathrm{U}$ & 100 & & NS & $\mu \mathrm{g} / \mathrm{L}$ \\
\hline Allyl chloride & WA & $\mathbf{R}$ & & $\mathrm{U}$ & 100 & & NS & $\mu \mathrm{g} / \mathrm{L}$ \\
\hline Benzene & WA & & & $\mathbf{U}$ & 5 & & 5 & $\mu \mathrm{g} / \mathrm{L}$ \\
\hline Benzene & WA & $\mathbf{R}$ & & $\mathrm{U}$ & 5 & & 5 & $\mu \mathrm{g} / \mathrm{L}$ \\
\hline
\end{tabular}


FHB014 (cont'd)

\begin{tabular}{|c|c|c|c|c|c|c|c|c|}
\hline Analyte & $\mathrm{Lab}$ & Rep & Avg & Qualifier & Result & Acc & Standard & Units \\
\hline Bromodichloromethane & WA & & & $\bar{U}$ & 5 & & NS & $\mu \mathrm{g} / \mathrm{L}$ \\
\hline Bromodichloromethane & WA & $\mathbf{R}$ & & $\mathrm{U}$ & 5 & & NS & $\mu \mathrm{g} / \mathrm{L}$ \\
\hline Bromoform & WA & & & $\mathrm{U}$ & 5 & & NS & $\mu \mathrm{g} / \mathrm{L}$ \\
\hline Bromoform & WA & $\mathbf{R}$ & & $U$ & 5 & & NS & $\mu \mathrm{g} / \mathrm{L}$ \\
\hline Carbon disulfide & WA & & & $\mathrm{U}$ & 5 & & NS & $\mu \mathrm{g} / \mathrm{L}$ \\
\hline Carbon disulfide & WA & $\mathbf{R}$ & & $\mathrm{U}$ & 5 & & NS & $\mu \mathrm{g} / \mathrm{L}$ \\
\hline Carbon tetrachloride & WA & & & $U$ & 5 & & 5 & $\mu \mathrm{g} / \mathrm{L}$ \\
\hline Carbon tetrachloride & WA & $\mathbf{R}$ & & $\mathrm{U}$ & 5 & & 5 & $\mu \mathrm{g} / \mathrm{L}$ \\
\hline Chlorobenzene & WA & & & $\mathrm{U}$ & 5 & & 100 & $\mu \mathrm{g} / \mathrm{L}$ \\
\hline Chlorobenzene & WA & $\mathbf{R}$ & & $\mathrm{U}$ & 5 & & 100 & $\mu \mathrm{g} / \mathrm{L}$ \\
\hline Chloroethane & WA & & & $\mathrm{U}$ & 10 & & NS & $\mu g / L$ \\
\hline Chloroethane & WA & $\mathbf{R}$ & & $\mathrm{U}$ & 10 & & NS & $\mu \mathrm{g} / \mathrm{L}$ \\
\hline Chloroform & WA & & & $\mathrm{U}$ & 5 & & 100 & $\mu \mathrm{g} / \mathrm{L}$ \\
\hline Chloroform & WA & $\mathbf{R}$ & & $\mathrm{U}$ & 5 & & 100 & $\mu \mathrm{g} / \mathrm{L}$ \\
\hline Chloroprene & WA & & & $\mathrm{U}$ & 20 & & NS & $\mu \mathrm{g} / \mathrm{L}$ \\
\hline Chloroprene & WA & $\mathbf{R}$ & & $\mathrm{U}$ & 20 & & NS & $\mu g / L$ \\
\hline cis-1,3-Dichloropropene & WA & & & $\mathrm{U}$ & 5 & & NS & $\mu \mathrm{g} / \mathrm{L}$ \\
\hline cis-1,3-Dichloropropene & WA & $\mathbf{R}$ & & $\mathrm{U}$ & 5 & & NS & $\mu \mathrm{g} / \mathrm{L}$ \\
\hline Dibromochloromethane & WA & & & U & 5 & & NS & $\mu \mathrm{g} / \mathrm{L}$ \\
\hline Dibromochloromethane & WA & $\mathbf{R}$ & & $\mathrm{U}$ & 5 & & NS & $\mu \mathrm{g} / \mathrm{L}$ \\
\hline Dichlorodifluoromethane & WA & & & $\mathbf{J}$ & 1.3 & & NS & $\mu \mathrm{g} / \mathrm{L}$ \\
\hline Dichlorodifluoromethane & WA & $\mathbf{R}$ & & $\mathbf{J}$ & 1.39 & & NS & $\mu \mathrm{g} / \mathrm{L}$ \\
\hline Ethylbenzene & WA & & & $\mathrm{U}$ & 5 & & 700 & $\mu \mathrm{g} / \mathrm{L}$ \\
\hline Ethylbenzene & WA & $\mathbf{R}$ & & $U$ & 5 & & 700 & $\mu \mathrm{g} / \mathrm{L}$ \\
\hline Isobutyl alcohol & WA & & & $\mathrm{U}$ & 20 & & NS & $\mu \mathrm{g} / \mathrm{L}$ \\
\hline Isobutyl alcohol & WA & $\mathbf{R}$ & & $\mathrm{U}$ & 20 & & NS & $\mu \mathrm{g} / \mathrm{L}$ \\
\hline Methacrylonitrile & WA & & & $\mathrm{U}$ & 20 & & NS & $\mu \mathrm{g} / \mathrm{L}$ \\
\hline Methacrylonitrile & WA & $\mathbf{R}$ & & $\mathrm{U}$ & 20 & & NS & $\mu \mathrm{g} / \mathrm{L}$ \\
\hline Methyl bromide & WA & & & U & 10 & & NS & $\mu \mathrm{g} / \mathrm{L}$ \\
\hline Methyl bromide & WA & $\mathbf{R}$ & & $\mathrm{U}$ & 10 & & NS & $\mu \mathrm{g} / \mathrm{L}$ \\
\hline Methyl chloride & WA & & & U & 10 & & NS & $\mu \mathrm{g} / \mathrm{L}$ \\
\hline Methyl chloride & WA & $\mathbf{R}$ & & $\mathbf{J}$ & 6.57 & & NS & $\mu \mathrm{g} / \mathrm{L}$ \\
\hline Methyl ethyl ketone & WA & & & $\mathrm{U}$ & 10 & & NS & $\mu \mathrm{g} / \mathrm{L}$ \\
\hline Methyl ethyl ketone & WA & $\mathbf{R}$ & & $\mathrm{U}$ & 10 & & NS & $\mu \mathrm{g} / \mathrm{L}$ \\
\hline Methyl iodide & WA & & & $\mathrm{U}$ & 10 & & NS & $\mu \mathrm{g} / \mathrm{L}$ \\
\hline Methyl iodide & WA & $\mathbf{R}$ & & U & 10 & & NS & $\mu \mathrm{g} / \mathrm{L}$ \\
\hline Methylene bromide & WA & & & $\mathrm{U}$ & 10 & & NS & $\mu \mathrm{g} / \mathrm{L}$ \\
\hline Methylene bromide & WA & $\mathbf{R}$ & & $\mathrm{U}$ & 10 & & NS & $\mu \mathrm{g} / \mathrm{L}$ \\
\hline Methylene chloride & WA & & & $\mathbf{J}$ & 1.16 & & 5 & $\mu \mathrm{g} / \mathrm{L}$ \\
\hline Methylene chloride & WA & $\mathbf{R}$ & & $\mathbf{J}$ & 1.03 & & 5 & $\mu \mathrm{g} / \mathrm{L}$ \\
\hline Propionitrile & WA & & & $\mathrm{U}$ & 50 & & NS & $\mu g / L$ \\
\hline Propionitrile & WA & $\mathbf{R}$ & & $\mathrm{U}$ & 50 & & NS & $\mu \mathrm{g} / \mathrm{L}$ \\
\hline Styrene & WA & & & $\mathrm{U}$ & 5 & & 100 & $\mu \mathrm{g} / \mathrm{L}$ \\
\hline Styrene & WA & $\mathbf{R}$ & & $\mathrm{U}$ & 5 & & 100 & $\mu \mathrm{g} / \mathrm{L}$ \\
\hline
\end{tabular}


FHB014 (cont'd)

\begin{tabular}{|c|c|c|c|c|c|c|c|c|}
\hline Analyte & Lab & $\operatorname{Rep}$ & Avg & Qualifier & Result & Acc & Standard & Units \\
\hline Tetrachloroethylene & WA & & & $\mathrm{U}$ & 5 & & 5 & $\mu \mathrm{g} / \mathrm{L}$ \\
\hline Tetrachloroethylene & WA & $\mathbf{R}$ & & $\mathrm{U}$ & 5 & & 5 & $\mu \mathrm{g} / \mathrm{L}$ \\
\hline Toluene & WA & & & $\mathrm{U}$ & 5 & & 1000 & $\mu \mathrm{g} / \mathrm{L}$ \\
\hline Toluene & WA & $\mathbf{R}$ & & $\mathrm{U}$ & 5 & & 1000 & $\mu \mathrm{g} / \mathrm{L}$ \\
\hline trans-1,3-Dichloropropene & WA & & & $U$ & 5 & & NS & $\mu \mathrm{g} / \mathrm{L}$ \\
\hline trans-1,3-Dichloropropene & WA & $\mathbf{R}$ & & $\mathrm{U}$ & 5 & & NS & $\mu g / L$ \\
\hline trans-1,4-Dichloro-2-butene & WA & & & $\mathrm{U}$ & 100 & & NS & $\mu \mathrm{g} / \mathrm{L}$ \\
\hline trans-1,4-Dichloro-2-butene & WA & R & & $U$ & 100 & & NS & $\mu \mathrm{g} / \mathrm{L}$ \\
\hline Trichloroethylene & WA & & & $\pi$ & 1.94 & & 5 & $\mu g / L$ \\
\hline Trichloroethylene & WA & $\mathbf{R}$ & & J & 1.86 & & 5 & $\mu \mathrm{g} / \mathrm{L}$ \\
\hline Trichlorofluoromethane & WA & & & $\mathrm{U}$ & 5 & & NS & $\mu \mathrm{g} / \mathrm{L}$ \\
\hline Trichlorofluoromethane & WA & $\mathbf{R}$ & & $\mathrm{U}$ & 5 & & NS & $\mu \mathrm{g} / \mathrm{L}$ \\
\hline Tritium & EMS & & & & 889 & 14 & 20 & $\mathrm{pCi} / \mathrm{ml}$ \\
\hline Tritium & EMS & $\mathbf{R}$ & & & 865 & 13 & 20 & $\mathrm{pCi} / \mathrm{ml}$ \\
\hline Vinyl acetate & WA & & & $\mathrm{U}$ & 10 & & NS & $\mu \mathrm{g} / \mathrm{L}$ \\
\hline Vinyl acetate & WA & $\mathbf{R}$ & & $\mathrm{U}$ & 10 & & NS & $\mu \mathrm{g} / \mathrm{L}$ \\
\hline Vinyl chloride & WA & & & $\mathrm{U}$ & 10 & & 2 & $\mu \mathrm{g} / \mathrm{L}$ \\
\hline Vinyl chloride & WA & $\mathbf{R}$ & & $\mathrm{U}$ & 10 & & 2 & $\mu \mathrm{g} / \mathrm{L}$ \\
\hline Xylenes (total) & WA & & & $\mathrm{U}$ & 5 & & 10000 & $\mu \mathrm{g} / \mathrm{L}$ \\
\hline Xylenes (total) & WA & $\mathbf{R}$ & & $\mathrm{U}$ & 5 & & 10000 & $\mu \mathrm{g} / \mathrm{L}$ \\
\hline
\end{tabular}


FHB014B

Field Measurements:

Sample Date: 08/25/94

pH: 4.86

Conductivity: $34 \mu \mathrm{S} / \mathrm{cm}$

\begin{tabular}{|c|c|c|c|c|c|c|c|c|}
\hline Analyte & Lab & Rep & Avg & Qualifier & Result & Acc & Standard & Units \\
\hline $1,1,1,2$-Tetrachloroethane & WA & & & $\bar{U}$ & 10 & & NS & $\mu \mathrm{g} / \mathrm{L}$ \\
\hline 1,1,1-Trichloroethane & WA & & & $\mathrm{U}$ & 5 & & 200 & $\mu \mathrm{g} / \mathrm{L}$ \\
\hline $1,1,2,2$-Tetrachloroethane & WA & & & $\mathrm{U}$ & 5 & & NS & $\mu \mathrm{g} / \mathrm{L}$ \\
\hline 1,1,2-Trichloroethane & WA & & & $\mathrm{U}$ & 5 & & 5 & $\mu \mathrm{g} / \mathrm{L}$ \\
\hline 1,1-Dichloroethane & WA & & & $\mathbf{U}$ & 5 & & NS & $\mu \mathrm{g} / \mathrm{L}$ \\
\hline 1,1-Dichloroethylene & WA & & & $\mathrm{U}$ & 5 & & 7 & $\mu \mathrm{g} / \mathrm{L}$ \\
\hline 1,2,3-Trichloropropane & WA & & & $\mathrm{U}$ & 10 & & NS & $\mu \mathrm{g} / \mathrm{L}$ \\
\hline 1,2-Dibromo-3-chloropropane & WA & & & $\mathrm{U}$ & 20 & & 0.2 & $\mu \mathrm{g} / \mathrm{L}$ \\
\hline 1,2-Dibromoethane & WA & & & $U$ & 20 & & NS & $\mu \mathrm{g} / \mathrm{L}$ \\
\hline 1,2-Dichloroethane & WA & & & $\mathrm{U}$ & 5 & & 5 & $\mu \mathrm{g} / \mathrm{L}$ \\
\hline 1,2-Dichloroethylene (total) & WA & & & & 13.6 & & 70 & $\mu \mathrm{g} / \mathrm{L}$ \\
\hline 1,2-Dichloropropane & WA & & & $\mathrm{U}$ & 5 & & 5 & $\mu \mathrm{g} / \mathrm{L}$ \\
\hline 2-Hexanone & WA & & & $\mathrm{U}$ & 10 & & NS & $\mu g / L$ \\
\hline 4-Methyl-2-pentanone & WA & & & $\mathrm{U}$ & 10 & & NS & $\mu \mathrm{g} / \mathrm{L}$ \\
\hline Acetone & WA & & & JV & 3.69 & & NS & $\mu \mathrm{g} / \mathrm{L}$ \\
\hline Acetonitrile (Methyl cyanide) & WA & & & $\mathrm{U}$ & 20 & & NS & $\mu \mathrm{g} / \mathrm{L}$ \\
\hline Acrolein & WA & & & $\mathrm{U}$ & 10 & & NS & $\mu \mathrm{g} / \mathrm{L}$ \\
\hline Acrylonitrile & WA & & & $\mathrm{U}$ & 10 & & NS & $\mu \mathrm{g} / \mathrm{L}$ \\
\hline Allyl chloride & WA & & & $\mathrm{U}$ & 100 & & NS & $\mu \mathrm{g} / \mathrm{L}$ \\
\hline Benzene & WA & & & $\mathrm{U}$ & 5 & & 5 & $\mu \mathrm{g} / \mathrm{L}$ \\
\hline Bromodichloromethane & WA & & & $\mathrm{U}$ & 5 & & NS & $\mu \mathrm{g} / \mathrm{L}$ \\
\hline Bromoform & WA & & & $\mathrm{U}$ & 5 & & NS & $\mu \mathrm{g} / \mathrm{L}$ \\
\hline Carbon disulfide & WA & & & $\mathrm{U}$ & 5 & & NS & $\mu \mathrm{g} / \mathrm{L}$ \\
\hline Carbon tetrachloride & WA & & & $\mathrm{U}$ & 5 & & 5 & $\mu \mathrm{g} / \mathrm{L}$ \\
\hline Chlorobenzene & WA & & & $\mathrm{U}$ & 5 & & 100 & $\mu \mathrm{g} / \mathrm{L}$ \\
\hline Chloroethane & WA & & & $\mathrm{U}$ & 10 & & NS & $\mu \mathrm{g} / \mathrm{L}$ \\
\hline Chloroform & WA & & & $\mathbf{U}$ & 5 & & 100 & $\mu \mathrm{g} / \mathrm{L}$ \\
\hline Chloroprene & WA & & & $\mathbf{U}$ & 20 & & NS & $\mu \mathrm{g} / \mathrm{L}$ \\
\hline cis-1,3-Dichloropropene & WA & & & $\mathrm{U}$ & 5 & & NS & $\mu \mathrm{g} / \mathrm{L}$ \\
\hline Dibromochloromethane & WA & & & $\mathrm{U}$ & 5 & & NS & $\mu \mathrm{g} / \mathrm{L}$ \\
\hline Dichlorodifluoromethane & WA & & & $\mathrm{U}$ & 10 & & NS & $\mu \mathrm{g} / \mathrm{L}$ \\
\hline Ethylbenzene & WA & & & $U$ & 5 & & 700 & $\mu \mathrm{g} / \mathrm{L}$ \\
\hline Isobutyl alcohol & WA & & & $\mathrm{U}$ & 20 & & NS & $\mu \mathrm{g} / \mathrm{L}$ \\
\hline Methacrylonitrile & WA & & & $\mathrm{U}$ & 20 & & NS & $\mu \mathrm{g} / \mathrm{L}$ \\
\hline Methyl bromide & WA & & & $\mathrm{U}$ & 10 & & NS & $\mu \mathrm{g} / \mathrm{L}$ \\
\hline Methyl chloride & WA & & & $\mathrm{U}$ & 10 & & NS & $\mu \mathrm{g} / \mathrm{L}$ \\
\hline Methyl ethyl ketone & WA & & & $\mathrm{U}$ & 10 & & NS & $\mu \mathrm{g} / \mathrm{L}$ \\
\hline Methyl iodide & WA & & & $U$ & 10 & & NS & $\mu \mathrm{g} / \mathrm{L}$ \\
\hline Methylene bromide & WA & & & $\mathbf{U}$ & 10 & & NS & $\mu \mathrm{g} / \mathrm{L}$ \\
\hline Methylene chloride & WA & & & $\mathbf{J}$ & 1.21 & & 5 & $\mu \mathrm{g} / \mathrm{L}$ \\
\hline Propionitrile & WA & & & $\mathrm{U}$ & 50 & & NS & $\mu \mathrm{g} / \mathrm{L}$ \\
\hline
\end{tabular}


FHB014B (cont'd)

\begin{tabular}{|c|c|c|c|c|c|c|c|c|}
\hline Analyte & Lab & Rep & Avg & Qualifier & Result & Acc & Standard & Units \\
\hline$\overline{\text { Styrene }}$ & WA & & & $\overline{\mathrm{U}}$ & 5 & & 100 & $\mu \mathrm{g} / \mathrm{L}$ \\
\hline Tetrachloroethylene & WA & & & $\mathrm{U}$ & 5 & & 5 & $\mu \mathrm{g} / \mathrm{L}$ \\
\hline Toluene & WA & & & $\mathrm{I}$ & 1.33 & & 1000 & $\mu \mathrm{g} / \mathrm{L}$ \\
\hline trans-1,3-Dichloropropene & WA & & & $\mathrm{U}$ & 5 & & NS & $\mu \mathrm{g} / \mathrm{L}$ \\
\hline trans-1,4-Dichloro-2-butene & WA & & & $\mathrm{U}$ & 100 & & NS & $\mu \mathrm{g} / \mathrm{L}$ \\
\hline Trichloroethylene & WA & & & $J$ & 1.57 & & 5 & $\mu \mathrm{g} / \mathrm{L}$ \\
\hline Trichlorofluoromethane & WA & & & $\mathrm{U}$ & 5 & & NS & $\mu \mathrm{g} / \mathrm{L}$ \\
\hline Tritium & EMS & & & & 601 & 6 & 20 & $\mathrm{pCi} / \mathrm{ml}$ \\
\hline Vinyl acetate & WA & & & $\mathbf{U}$ & 10 & & NS & $\mu \mathrm{g} / \mathrm{L}$ \\
\hline Vinyl chloride & WA & & & $\mathrm{U}$ & 10 & & 2 & $\mu \mathrm{g} / \mathrm{L}$ \\
\hline Xylenes (total) & WA & & & U & 5 & & 10000 & $\mu \mathrm{g} / \mathrm{L}$ \\
\hline
\end{tabular}


FHB016

Field Measurements:

Sample Date: 08/25/94

Depth to Water: $5.14 \mathrm{ft}$ below TOC

Water Level Elevation: $216 \mathrm{msl}$

pH: 5.61

Conductivity: $47 \mu \mathrm{S} / \mathrm{cm}$

\begin{tabular}{|c|c|c|c|c|c|c|c|c|}
\hline Analyte & Lab & Rep & Avg & Qualifier & Result & Acc & Standard & Units \\
\hline 1,1,1,2-Tetrachloroethane & WA & & & $\overline{\mathrm{U}}$ & 10 & & NS & $\mu \mathrm{g} / \mathrm{L}$ \\
\hline 1,1,1-Trichloroethane & WA & & & $\mathrm{U}$ & 5 & & 200 & $\mu \mathrm{g} / \mathrm{L}$ \\
\hline 1,1,2,2-Tetrachloroethane & WA & & & $\mathrm{U}$ & 5 & & NS & $\mu \mathrm{g} / \mathrm{L}$ \\
\hline 1,1,2-Trichloroethane & WA & & & $\mathbf{U}$ & 5 & & 5 & $\mu \mathrm{g} / \mathrm{L}$ \\
\hline 1,1-Dichloroethane & WA & & & $\mathrm{U}$ & 5 & & NS & $\mu \mathrm{g} / \mathrm{L}$ \\
\hline 1,1-Dichloroethylene & WA & & & $\mathrm{U}$ & 5 & & 7 & $\mu \mathrm{g} / \mathrm{L}$ \\
\hline 1,2,3-Trichloropropane & WA & & & $\mathrm{U}$ & 10 & & NS & $\mu \mathrm{g} / \mathrm{L}$ \\
\hline 1,2-Dibromo-3-chloropropane & WA & & & $\mathbf{U}$ & 20 & & 0.2 & $\mu g / L$ \\
\hline 1,2-Dibromoethane & WA & & & $\mathbf{U}$ & 20 & & NS & $\mu \mathrm{g} / \mathrm{L}$ \\
\hline 1,2-Dichloroethane & WA & & & $\mathrm{U}$ & 5 & & 5 & $\mu \mathrm{g} / \mathrm{L}$ \\
\hline 1,2-Dichloroethylene (total) & WA & & & & 4.78 & & 70 & $\mu g / L$ \\
\hline 1,2-Dichloropropane & WA & & & $\mathbf{U}$ & 5 & & 5 & $\mu \mathrm{g} / \mathrm{L}$ \\
\hline 2-Hexanone & WA & & & $\mathrm{U}$ & 10 & & NS & $\mu \mathrm{g} / \mathrm{L}$ \\
\hline 4-Methyl-2-pentanone & WA & & & $\mathbf{U}$ & 10 & & NS & $\mu \mathrm{g} / \mathrm{L}$ \\
\hline Acetone & WA & & & $\mathrm{U}$ & 10 & & NS & $\mu \mathrm{g} / \mathrm{L}$ \\
\hline Acetonitrile (Methyl cyanide) & WA & & & $\mathrm{U}$ & 20 & & NS & $\mu \mathrm{g} / \mathrm{L}$ \\
\hline Acrolein & WA & & & $\mathrm{U}$ & 10 & & NS & $\mu \mathrm{g} / \mathrm{L}$ \\
\hline Acrylonitrile & WA & & & $U$ & 10 & & NS & $\mu \mathrm{g} / \mathrm{L}$ \\
\hline Allyl chloride & WA & & & $\mathrm{U}$ & 100 & & NS & $\mu \mathrm{g} / \mathrm{L}$ \\
\hline Benzene & WA & & & $\mathrm{U}$ & 5 & & 5 & $\mu \mathrm{g} / \mathrm{L}$ \\
\hline Bromodichloromethane & WA & & & $\mathbf{U}$ & 5 & & NS & $\mu \mathrm{g} / \mathrm{L}$ \\
\hline Bromoform & WA & & & $\mathrm{U}$ & 5 & & NS & $\mu \mathrm{g} / \mathrm{L}$ \\
\hline Carbon disulfide & WA & & & $\mathrm{U}$ & 5 & & NS & $\mu \mathrm{g} / \mathrm{L}$ \\
\hline Carbon tetrachloride & WA & & & $\mathrm{U}$ & 5 & & 5 & $\mu \mathrm{g} / \mathrm{L}$ \\
\hline Chlorobenzene & WA & & & $\mathbf{U}$ & 5 & & 100 & $\mu \mathrm{g} / \mathrm{L}$ \\
\hline Chloroethane & WA & & & $\mathrm{U}$ & 10 & & NS & $\mu \mathrm{g} / \mathrm{L}$ \\
\hline Chloroform & WA & & & $\mathbf{U}$ & 5 & & 100 & $\mu \mathrm{g} / \mathrm{L}$ \\
\hline Chloroprene & WA & & & $\mathrm{U}$ & 20 & & NS & $\mu g / L$ \\
\hline cis-1,3-Dichloropropene & WA & & & $\mathrm{U}$ & 5 & & NS & $\mu \mathrm{g} / \mathrm{L}$ \\
\hline Dibromochloromethane & WA & & & $\mathrm{U}$ & 5 & & NS & $\mu \mathrm{g} / \mathrm{L}$ \\
\hline Dichlorodifluoromethane & WA & & & $\mathrm{U}$ & 10 & & NS & $\mu \mathrm{g} / \mathrm{L}$ \\
\hline Ethylbenzene & WA & & & $\mathbf{J}$ & 1.26 & & 700 & $\mu \mathrm{g} / \mathrm{L}$ \\
\hline Isobutyl alcohol & WA & & & $\mathrm{U}$ & 20 & & NS & $\mu \mathrm{g} / \mathrm{L}$ \\
\hline Methacrylonitrile & WA & & & $\mathrm{U}$ & 20 & & NS & $\mu \mathrm{g} / \mathrm{L}$ \\
\hline Methyl bromide & WA & & & $\mathrm{U}$ & 10 & & NS & $\mu \mathrm{g} / \mathrm{L}$ \\
\hline Methyl chloride & WA & & & $\mathrm{U}$ & 10 & & NS & $\mu \mathrm{g} / \mathrm{L}$ \\
\hline Methyl ethyl ketone & WA & & & $U$ & 10 & & NS & $\mu \mathrm{g} / \mathrm{L}$ \\
\hline Methyl iodide & WA & & & $\mathrm{U}$ & 10 & & NS & $\mu \mathrm{g} / \mathrm{L}$ \\
\hline Methylene bromide & WA & & & $\mathbf{U}$ & 10 & & NS & $\mu \mathrm{g} / \mathrm{L}$ \\
\hline Methylene chloride & WA & & & $U$ & 5 & & 5 & $\mu \mathrm{g} / \mathrm{L}$ \\
\hline
\end{tabular}


FHB016 (cont'd)

\begin{tabular}{|c|c|c|c|c|c|c|c|c|}
\hline Analyte & Lab & Rep & Avg & Qualifier & Result & Acc & Standard & Units \\
\hline$\overline{\text { Propionitrile }}$ & WA & & & $\overline{\mathrm{U}}$ & 50 & & $\overline{\mathrm{NS}}$ & $\mu \mathrm{g} / \mathrm{L}$ \\
\hline Styrene & WA & & & $\mathrm{U}$ & 5 & & 100 & $\mu \mathrm{g} / \mathrm{L}$ \\
\hline Tetrachloroethylene & WA & & & $\mathrm{U}$ & 5 & & 5 & $\mu \mathrm{g} / \mathrm{L}$ \\
\hline Toluene & WA & & & $\mathrm{U}$ & 5 & & 1000 & $\mu \mathrm{g} / \mathrm{L}$ \\
\hline trans-1,3-Dichloropropene & WA & & & $\mathrm{U}$ & 5 & & NS & $\mu g / L$ \\
\hline trans-1,4-Dichloro-2-butene & WA & & & $\mathrm{U}$ & 100 & & NS & $\mu g / L$ \\
\hline Trichloroethylene & WA & & & $\mathrm{U}$ & 5 & & 5 & $\mu \mathrm{g} / \mathrm{L}$ \\
\hline Trichlorofluoromethane & WA & & & U & 5 & & NS & $\mu \mathrm{g} / \mathrm{L}$ \\
\hline Tritium & EMS & & & & 1520 & 19 & 20 & $\mathrm{pCi} / \mathrm{ml}$ \\
\hline Vinyl acetate & WA & & & $\mathrm{U}$ & 10 & & NS & $\mu \mathrm{g} / \mathrm{L}$ \\
\hline Vinyl chloride & WA & & & $\mathbb{U}$ & 10 & & 2 & $\mu \mathrm{g} / \mathrm{L}$ \\
\hline Xylenes (total) & WA & & & U & 5 & & 10000 & $\mu \mathrm{g} / \mathrm{L}$ \\
\hline
\end{tabular}


FHB017

Field Measurements:

Sample Date: 08/25/94

Depth to Water: $4.2 \mathrm{ft}$ below TOC

Water Level Elevation: $215 \mathrm{msl}$

pH: 4.94

Conductivity: $55 \mu \mathrm{S} / \mathrm{cm}$

\begin{tabular}{|c|c|c|c|c|c|c|c|c|}
\hline Analyte & Lab & Rep & Avg & Qualifier & Result & $\mathrm{Acc}$ & Standard & Units \\
\hline 1,1,1,2-Tetrachloroethane & WA & & & $\bar{U}$ & 10 & & NS & $\mu \mathrm{g} / \mathrm{L}$ \\
\hline 1,1,1-Trichloroethane & WA & & & $\mathbf{U}$ & 5 & & 200 & $\mu g / L$ \\
\hline 1,1,2,2-Tetrachloroethane & WA & & & $\mathrm{U}$ & 5 & & NS & $\mu \mathrm{g} / \mathrm{L}$ \\
\hline 1,1,2-Trichloroethane & WA & & & $\mathbf{U}$ & 5 & & 5 & $\mu \mathrm{g} / \mathrm{L}$ \\
\hline 1,1-Dichloroethane & WA & & & $\mathbf{U}$ & 5 & & NS & $\mu \mathrm{g} / \mathrm{L}$ \\
\hline 1,1-Dichloroethylene & WA & & & $\mathbf{U}$ & 5 & & 7 & $\mu \mathrm{g} / \mathrm{L}$ \\
\hline 1,2,3-Trichloropropane & WA & & & $\mathbf{U}$ & 10 & & NS & $\mu \mathrm{g} / \mathrm{L}$ \\
\hline 1,2-Dibromo-3-chloropropane & WA & & & $\mathrm{U}$ & 20 & & 0.2 & $\mu \mathrm{g} / \mathrm{L}$ \\
\hline 1,2-Dibromoethane & WA & & & $\mathrm{U}$ & 20 & & NS & $\mu \mathrm{g} / \mathrm{L}$ \\
\hline 1,2-Dichloroethane & WA & & & $\mathrm{U}$ & 5 & & 5 & $\mu \mathrm{g} / \mathrm{L}$ \\
\hline 1,2-Dichloroethylene (total) & WA & & & & 35.9 & & 70 & $\mu \mathrm{g} / \mathrm{L}$ \\
\hline 1,2-Dichloropropane & WA & & & $\mathrm{U}$ & 5 & & 5 & $\mu \mathrm{g} / \mathrm{L}$ \\
\hline 2-Hexanone & WA & & & $\mathrm{U}$ & 10 & & NS & $\mu \mathrm{g} / \mathrm{L}$ \\
\hline 4-Methyl-2-pentanone & WA & & & $\mathrm{U}$ & 10 & & NS & $\mu \mathrm{g} / \mathrm{L}$ \\
\hline Acetone & WA & & & $\mathrm{U}$ & 10 & & NS & $\mu \mathrm{g} / \mathrm{L}$ \\
\hline Acetonitrile (Methyl cyanide) & WA & & & $\mathrm{U}$ & 20 & & NS & $\mu \mathrm{g} / \mathrm{L}$ \\
\hline Acrolein & WA & & & $\mathrm{U}$ & 10 & & NS & $\mu \mathrm{g} / \mathrm{L}$ \\
\hline Acrylonitrile & WA & & & $\mathrm{U}$ & 10 & & NS & $\mu \mathrm{g} / \mathrm{L}$ \\
\hline Allyl chloride & WA & & & $\mathrm{U}$ & 100 & & NS & $\mu \mathrm{g} / \mathrm{L}$ \\
\hline Benzene & WA & & & $\mathbf{U}$ & 5 & & 5 & $\mu \mathrm{g} / \mathrm{L}$ \\
\hline Bromodichloromethane & WA & & & $\mathrm{U}$ & 5 & & NS & $\mu \mathrm{g} / \mathrm{L}$ \\
\hline Bromoform & WA & & & $\mathrm{U}$ & 5 & & NS & $\mu \mathrm{g} / \mathrm{L}$ \\
\hline Carbon disulfide & WA & & & $\mathrm{U}$ & 5 & & NS & $\mu \mathrm{g} / \mathrm{L}$ \\
\hline Carbon tetrachloride & WA & & & $\mathrm{U}$ & 5 & & 5 & $\mu \mathrm{g} / \mathrm{L}$ \\
\hline Chlorobenzene & WA & & & $\mathrm{U}$ & 5 & & 100 & $\mu \mathrm{g} / \mathrm{L}$ \\
\hline Chloroethane & WA & & & $U$ & 10 & & NS & $\mu \mathrm{g} / \mathrm{L}$ \\
\hline Chloroform & WA & & & $\mathbf{J}$ & 1.76 & & 100 & $\mu \mathrm{g} / \mathrm{L}$ \\
\hline Chloroprene & WA & & & $\mathbf{U}$ & 20 & & NS & $\mu \mathrm{g} / \mathrm{L}$ \\
\hline cis-1,3-Dichloropropene & WA & & & $\mathrm{U}$ & 5 & & NS & $\mu \mathrm{g} / \mathrm{L}$ \\
\hline Dibromochloromethane & WA & & & $\mathbf{U}$ & 5 & & NS & $\mu \mathrm{g} / \mathrm{L}$ \\
\hline Dichlorodifluoromethane & WA & & & $\mathbf{J}$ & 1.86 & & NS & $\mu \mathrm{g} / \mathrm{L}$ \\
\hline Ethylbenzene & WA & & & $U$ & 5 & & 700 & $\mu \mathrm{g} / \mathrm{L}$ \\
\hline Isobutyl alcohol & WA & & & $\mathrm{U}$ & 20 & & NS & $\mu \mathrm{g} / \mathrm{L}$ \\
\hline Methacrylonitrile & WA & & & $\mathrm{U}$ & 20 & & NS & $\mu \mathrm{g} / \mathrm{L}$ \\
\hline Methyl bromide & WA & & & $\mathbf{U}$ & 10 & & NS & $\mu \mathrm{g} / \mathrm{L}$ \\
\hline Methyl chloride & WA & & & $U$ & 10 & & NS & $\mu \mathrm{g} / \mathrm{L}$ \\
\hline Methyl ethyl ketone & WA & & & $\mathrm{U}$ & 10 & & NS & $\mu \mathrm{g} / \mathrm{L}$ \\
\hline Methyl iodide & WA & & & $U$ & 10 & & NS & $\mu \mathrm{g} / \mathrm{L}$ \\
\hline Methylene bromide & WA & & & $\mathrm{U}$ & 10 & & NS & $\mu \mathrm{g} / \mathrm{L}$ \\
\hline Methylene chloride & WA & & & $\mathrm{U}$ & 5 & & 5 & $\mu \mathrm{g} / \mathrm{L}$ \\
\hline
\end{tabular}


FHB017 (cont'd)

\begin{tabular}{|c|c|c|c|c|c|c|c|c|}
\hline Analyte & Lab & Rep & Avg & Qualifier & Result & Acc & Standard & Units \\
\hline Propionitrile & WA & & & $\bar{U}$ & 50 & & NS & $\mu \mathrm{g} / \mathrm{L}$ \\
\hline Styrene & WA & & & $\mathrm{U}$ & 5 & & 100 & $\mu \mathrm{g} / \mathrm{L}$ \\
\hline Tetrachloroethylene & WA & & & $\mathrm{J}$ & 4.3 & & 5 & $\mu \mathrm{g} / \mathrm{L}$ \\
\hline Toluene & WA & & & $\mathrm{U}$ & 5 & & 1000 & $\mu \mathrm{g} / \mathrm{L}$ \\
\hline trans-1,3-Dichloropropene & WA & & & $\mathrm{U}$ & 5 & & NS & $\mu \mathrm{g} / \mathrm{L}$ \\
\hline trans-1,4-Dichloro-2-butene & WA & & & $\mathrm{U}$ & 100 & & NS & $\mu \mathrm{g} / \mathrm{L}$ \\
\hline Trichloroethylene & WA & & & & 13.2 & & 5 & $\mu \mathrm{g} / \mathrm{L}$ \\
\hline Trichlorofluoromethane & WA & & & $\mathrm{U}$ & 5 & & NS & $\mu \mathrm{g} / \mathrm{L}$ \\
\hline Tritium & EMS & & & & 35500 & 350 & 20 & $\mathrm{pCi} / \mathrm{ml}$ \\
\hline Vinyl acetate & WA & & & $\mathrm{U}$ & 10 & & NS & $\mu \mathrm{g} / \mathrm{L}$ \\
\hline Vinyl chloride & WA & & & $\mathrm{U}$ & 10 & & 2 & $\mu \mathrm{g} / \mathrm{L}$ \\
\hline Xylenes (total) & WA & & & U & 5 & & 10000 & $\mu \mathrm{g} / \mathrm{L}$ \\
\hline
\end{tabular}


FHB018

Field Measurements:

Sample Date: 08/25/94

Depth to Water: $4.6 \mathrm{ft}$ below TOC

Water Level Elevation: $213 \mathrm{msl}$

$\mathrm{pH}: 5.76$

Conductivity: $53 \mu \mathrm{S} / \mathrm{cm}$

\begin{tabular}{|c|c|c|c|c|c|c|c|c|}
\hline Analyte & $\mathrm{Lab}$ & Rep & Avg & Qualifier & Result & Acc & Standard & Units \\
\hline 1,1,1,2-Tetrachloroethane & WA & & & $\bar{U}$ & 10 & & NS & $\mu \mathrm{g} / \mathrm{L}$ \\
\hline 1,1,1-Trichloroethane & ADS & & & $\mathrm{U}$ & 50 & & 200 & $\mu \mathrm{g} / \mathrm{L}$ \\
\hline 1,1,1-Trichloroethane & WA & & & $\mathrm{U}$ & 5 & & 200 & $\mu \mathrm{g} / \mathrm{L}$ \\
\hline 1,1,2,2-Tetrachloroethane & ADS & & & $\mathrm{U}$ & 50 & & NS & $\mu \mathrm{g} / \mathrm{L}$ \\
\hline 1,1,2,2-Tetrachloroethane & WA & & & $\mathrm{U}$ & 5 & & NS & $\mu \mathrm{g} / \mathrm{L}$ \\
\hline 1,1,2-Trichloroethane & ADS & & & $\mathrm{U}$ & 50 & & 5 & $\mu \mathrm{g} / \mathrm{L}$ \\
\hline 1,1,2-Trichloroethane & WA & & & $U$ & 5 & & 5 & $\mu \mathrm{g} / \mathrm{L}$ \\
\hline 1,1-Dichloroethane & ADS & & & $\mathrm{U}$ & 50 & & NS & $\mu \mathrm{g} / \mathrm{L}$ \\
\hline 1,1-Dichloroethane & WA & & & $\mathrm{U}$ & 5 & & NS & $\mu \mathrm{g} / \mathrm{L}$ \\
\hline 1,1-Dichloroethene & ADS & & & $\mathrm{U}$ & 50 & & 7 & $\mu \mathrm{g} / \mathrm{L}$ \\
\hline 1,1-Dichloroethylene & WA & & & $\mathrm{U}$ & 5 & & 7 & $\mu \mathrm{g} / \mathrm{L}$ \\
\hline 1,2,3-Trichloropropane & WA & & & $\mathrm{U}$ & 10 & & NS & $\mu \mathrm{g} / \mathrm{L}$ \\
\hline 1,2-Dibromo-3-chloropropane & WA & & & $\mathrm{U}$ & 20 & & 0.2 & $\mu \mathrm{g} / \mathrm{L}$ \\
\hline 1,2-Dibromoethane & WA & & & $\mathrm{U}$ & 20 & & NS & $\mu \mathrm{g} / \mathrm{L}$ \\
\hline 1,2-Dichloroethane & $\mathrm{ADS}$ & & & $\mathrm{U}$ & 50 & & 5 & $\mu \mathrm{g} / \mathrm{L}$ \\
\hline 1,2-Dichloroethane & WA & & & $\mathrm{U}$ & 5 & & 5 & $\mu \mathrm{g} / \mathrm{L}$ \\
\hline 1,2-Dichloroethylene (total) & WA & & & & 336 & & 70 & $\mu \mathrm{g} / \mathrm{L}$ \\
\hline 1,2-Dichloroethylene (total) ${ }^{1}$ & WA & & & L & 319 & & 70 & $\mu \mathrm{g} / \mathrm{L}$ \\
\hline 1,2-Dichloropropane & ADS & & & $\mathrm{U}$ & 50 & & 5 & $\mu \mathrm{g} / \mathrm{L}$ \\
\hline 1,2-Dichloropropane & WA & & & $\mathrm{U}$ & 5 & & 5 & $\mu \mathrm{g} / \mathrm{L}$ \\
\hline 2-Butanone & ADS & & & $\mathbf{U}$ & 50 & & NS & $\mu \mathrm{g} / \mathrm{L}$ \\
\hline 2-Hexanone & ADS & & & $\mathrm{U}$ & 50 & & NS & $\mu \mathrm{g} / \mathrm{L}$ \\
\hline 2-Hexanone & WA & & & $\mathrm{U}$ & 10 & & NS & $\mu \mathrm{g} / \mathrm{L}$ \\
\hline 4-Methyl-2-Pentanone & ADS & & & $U$ & 50 & & NS & $\mu \mathrm{g} / \mathrm{L}$ \\
\hline 4-Methyl-2-pentanone & WA & & & $\mathrm{U}$ & 10 & & NS & $\mu \mathrm{g} / \mathrm{L}$ \\
\hline Acetone & ADS & & & U & 50 & & NS & $\mu \mathrm{g} / \mathrm{L}$ \\
\hline Acetone & WA & & & $\mathrm{U}$ & 10 & & NS & $\mu \mathrm{g} / \mathrm{L}$ \\
\hline Acetonitrile (Methyl cyanide) & WA & & & $\mathrm{U}$ & 20 & & NS & $\mu \mathrm{g} / \mathrm{L}$ \\
\hline Acrolein & WA & & & $\mathrm{U}$ & 10 & & NS & $\mu \mathrm{g} / \mathrm{L}$ \\
\hline Acrylonitrile & WA & & & $U$ & 10 & & NS & $\mu \mathrm{g} / \mathrm{L}$ \\
\hline Allyl chloride & WA & & & $\mathrm{U}$ & 100 & & NS & $\mu \mathrm{g} / \mathrm{L}$ \\
\hline Benzene & ADS & & & $\mathrm{J}$ & 2 & & 5 & $\mu \mathrm{g} / \mathrm{L}$ \\
\hline Benzene & WA & & & $\mathrm{U}$ & 5 & & 5 & $\mu \mathrm{g} / \mathrm{L}$ \\
\hline Bromodichloromethane & ADS & & & $\mathrm{U}$ & 50 & & NS & $\mu g / L$ \\
\hline Bromodichloromethane & WA & & & $\mathbf{U}$ & 5 & & NS & $\mu \mathrm{g} / \mathrm{L}$ \\
\hline Bromoform & ADS & & & U & 50 & & NS & $\mu g / L$ \\
\hline Bromoform & WA & & & $\mathrm{U}$ & 5 & & NS & $\mu \mathrm{g} / \mathrm{L}$ \\
\hline Bromomethane & ADS & & & $\mathrm{U}$ & 50 & & NS & $\mu \mathrm{g} / \mathrm{L}$ \\
\hline Carbon Disulfide & ADS & & & $J$ & 1 & & NS & $\mu \mathrm{g} / \mathrm{L}$ \\
\hline Carbon disulfide & WA & & & $\mathrm{U}$ & 5 & & NS & $\mu \mathrm{g} / \mathrm{L}$ \\
\hline
\end{tabular}

I This sample was rerun and the result used for data analysis was the second analysis value (336 $\mu \mathrm{g} / \mathrm{L})$. 
FHB018 (cont'd)

\begin{tabular}{|c|c|c|c|c|c|c|c|}
\hline Analyte & Lab & Rep & Qualifier & Result & Acc & Standard & Units \\
\hline Carbon Tetrachloride & $\mathrm{ADS}$ & & $\bar{U}$ & 50 & & 5 & $\mu \mathrm{g} / \mathrm{L}$ \\
\hline Carbon tetrachloride & WA & & $\mathrm{U}$ & 5 & & 5 & $\mu \mathrm{g} / \mathrm{L}$ \\
\hline Chlorobenzene & ADS & & $\mathrm{U}$ & 50 & & 100 & $\mu \mathrm{g} / \mathrm{L}$ \\
\hline Chlorobenzene & WA & & $\mathrm{U}$ & 5 & & 100 & $\mu g / L$ \\
\hline Chloroethane & ADS & & $\mathrm{U}$ & 50 & & NS & $\mu \mathrm{g} / \mathrm{L}$ \\
\hline Chloroethane & WA & & $\mathrm{U}$ & 10 & & NS & $\mu \mathrm{g} / \mathrm{L}$ \\
\hline Chloroform & $\mathrm{ADS}$ & & $\mathrm{U}$ & 50 & & 100 & $\mu \mathrm{g} / \mathrm{L}$ \\
\hline Chloroform & WA & & $\mathrm{U}$ & 5 & & 100 & $\mu \mathrm{g} / \mathrm{L}$ \\
\hline Chloromethane & ADS & & $U$ & 50 & & NS & $\mu \mathrm{g} / \mathrm{L}$ \\
\hline Chloroprene & WA & & $u$ & 20 & & NS & $\mu g / L$ \\
\hline cis-1,2-Dichloroethene & ADS & & & 393 & & 70 & $\mu \mathrm{g} / \mathrm{L}$ \\
\hline cis-1,3-Dichloropropene & ADS & & $U$ & 50 & & NS & $\mu \mathrm{g} / \mathrm{L}$ \\
\hline cis-1,3-Dichloropropene & WA & & $\mathrm{U}$ & 5 & & NS & $\mu \mathrm{g} / \mathrm{L}$ \\
\hline Dibromochloromethane & ADS & & $U$ & 50 & & NS & $\mu \mathrm{g} / \mathrm{L}$ \\
\hline Dibromochloromethane & WA & & $U$ & 5 & & NS & $\mu \mathrm{g} / \mathrm{L}$ \\
\hline Dichlorodifluoromethane & WA & & $\mathrm{y}$ & 3.55 & & NS & $\mu \mathrm{g} / \mathrm{L}$ \\
\hline Ethylbenzene & ADS & & $\mathrm{j}$ & 3 & & 700 & $\mu \mathrm{g} / \mathrm{L}$ \\
\hline Ethylbenzene & WA & & $\mathrm{J}$ & 1.31 & & 700 & $\mu \mathrm{g} / \mathrm{L}$ \\
\hline Isobutyl alcohol & WA & & $\mathrm{U}$ & 20 & & NS & $\mu \mathrm{g} / \mathrm{L}$ \\
\hline Methacrylonitrile & WA & & $\mathrm{U}$ & 20 & & NS & $\mu \mathrm{g} / \mathrm{L}$ \\
\hline Methyl bromide & WA & & $\mathrm{U}$ & 10 & & NS & $\mu \mathrm{g} / \mathrm{L}$ \\
\hline Methyl chloride & WA & & $\mathrm{U}$ & 10 & & NS & $\mu \mathrm{g} / \mathrm{L}$ \\
\hline Methyl ethyl ketone & WA & & $\mathrm{U}$ & 10 & & NS & $\mu \mathrm{g} / \mathrm{L}$ \\
\hline Methyl iodide & WA & & $\mathbf{U}$ & 10 & & NS & $\mu \mathrm{g} / \mathrm{L}$ \\
\hline Methylene bromide & WA & & $\mathrm{U}$ & 10 & & NS & $\mu \mathrm{g} / \mathrm{L}$ \\
\hline Methylene Chloride & ADS & & $\mathbf{J}$ & 2 & & 5 & $\mu \mathrm{g} / \mathrm{L}$ \\
\hline Methylene chloride & WA & & $U$ & 5 & & 5 & $\mu \mathrm{g} / \mathrm{L}$ \\
\hline Propionitrile & WA & & $\mathrm{U}$ & 50 & & NS & $\mu g / L$ \\
\hline Styrene & $\mathrm{ADS}$ & & $\mathrm{U}$ & 50 & & 100 & $\mu \mathrm{g} / \mathrm{L}$ \\
\hline Styrene & WA & & $\mathrm{U}$ & 5 & & 100 & $\mu \mathrm{g} / \mathrm{L}$ \\
\hline Tetrachloroethene & ADS & & $\mathbf{J}$ & 5 & & 5 & $\mu \mathrm{g} / \mathrm{L}$ \\
\hline Tetrachloroethylene & WA & & $\mathrm{U}$ & 5 & & 5 & $\mu \mathrm{g} / \mathrm{L}$ \\
\hline Toluene & $\mathrm{ADS}$ & & $\mathrm{U}$ & 50 & & 1000 & $\mu \mathrm{g} / \mathrm{L}$ \\
\hline Toluene & WA & & U & 5 & & 1000 & $\mu \mathrm{g} / \mathrm{L}$ \\
\hline trans-1,2-Dichloroethene & $\mathrm{ADS}$ & & $\mathrm{J}$ & 5 & & 100 & $\mu \mathrm{g} / \mathrm{L}$ \\
\hline trans-1,3-Dichloropropene & ADS & & $\mathrm{U}$ & 50 & & NS & $\mu \mathrm{g} / \mathrm{L}$ \\
\hline trans-1,3-Dichloropropene & WA & & $\mathrm{U}$ & 5 & & NS & $\mu \mathrm{g} / \mathrm{L}$ \\
\hline trans-1,4-Dichloro-2-butene & WA & & $\mathrm{U}$ & 100 & & NS & $\mu \mathrm{g} / \mathrm{L}$ \\
\hline Trichloroethene & ADS & & $\mathrm{U}$ & 50 & & 5 & $\mu \mathrm{g} / \mathrm{L}$ \\
\hline Trichloroethylene & WA & & $J$ & 1.48 & & 5 & $\mu \mathrm{g} / \mathrm{L}$ \\
\hline Trichlorofluoromethane & WA & & $\mathbf{U}$ & 5 & & NS & $\mu \mathrm{g} / \mathrm{L}$ \\
\hline Tritium & EMS & & & 61300 & 570 & 20 & $\mathrm{pCi} / \mathrm{ml}$ \\
\hline Vinyl Acetate & $\mathrm{ADS}$ & & $\mathrm{U}$ & 50 & & NS & $\mu \mathrm{g} / \mathrm{L}$ \\
\hline Vinyl acetate & WA & & $\mathrm{U}$ & 10 & & NS & $\mu \mathrm{g} / \mathrm{L}$ \\
\hline Vinyl Chloride & ADS & & $\mathrm{U}$ & 50 & & 2 & $\mu \mathrm{g} / \mathrm{L}$ \\
\hline Vinyl chloride & WA & & $\mathrm{U}$ & 10 & & 2 & $\mu \mathrm{g} / \mathrm{L}$ \\
\hline
\end{tabular}


FHB018 (cont'd)

Analyte

Lab $\quad$ Rep $\quad$ Avg $\quad$ Qual

Xylenes (total)

ADS

\begin{tabular}{ccccc} 
Qualifier & Result & Acc & Standard & Units \\
\hline $\mathrm{U}$ & 5 & & 10000 & $\mu \mathrm{g} / \mathrm{L}$ \\
$\mathrm{U}$ & 100 & & 10000 & $\mu \mathrm{g} / \mathrm{L}$ \\
\hline
\end{tabular}

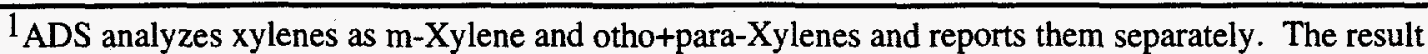
reported is the sum of the two analytes. 
FHB018B

Field Measurements:

Sample Date: 08/25/94

pH: 5.72

Conductivity: $196 \mu \mathrm{S} / \mathrm{cm}$

\begin{tabular}{|c|c|c|c|c|c|c|c|}
\hline Analyte & $\mathrm{Lab}$ & Rep Avg & Qualifier & Result & Acc & Standard & Units \\
\hline 1,1,1,2-Tetrachloroethane & WA & & $\bar{U}$ & 10 & & NS & $\mu \mathrm{g} / \mathrm{L}$ \\
\hline 1,1,1-Trichloroethane & WA & & $U$ & 5 & & 200 & $\mu g / L$ \\
\hline 1,1,2,2-Tetrachloroethane & WA & & $U$ & 5 & & NS & $\mu \mathrm{g} / \mathrm{L}$ \\
\hline 1,1,2-Trichloroethane & WA & & $U$ & 5 & & 5 & $\mu \mathrm{g} / \mathrm{L}$ \\
\hline 1,1-Dichloroethane & WA & & $\mathrm{U}$ & 5 & & NS & $\mu \mathrm{g} / \mathrm{L}$ \\
\hline 1,1-Dichloroethylene & WA & & $\mathbf{U}$ & 5 & & 7 & $\mu \mathrm{g} / \mathrm{L}$ \\
\hline 1,2,3-Trichloropropane & WA & & U & 10 & & NS & $\mu \mathrm{g} / \mathrm{L}$ \\
\hline 1,2-Dibromo-3-chloropropane & WA & & $\mathbf{U}$ & 20 & & 0.2 & $\mu \mathrm{g} / \mathrm{L}$ \\
\hline 1,2-Dibromoethane & WA & & U & 20 & & NS & $\mu \mathrm{g} / \mathrm{L}$ \\
\hline 1,2-Dichloroethane & WA & & $\mathrm{U}$ & 5 & & 5 & $\mu \mathrm{g} / \mathrm{L}$ \\
\hline 1,2-Dichloroethylene (total) & WA & & & 85.4 & & 70 & $\mu \mathrm{g} / \mathrm{L}$ \\
\hline 1,2-Dichloropropane & WA & & $\mathrm{U}$ & 5 & & 5 & $\mu \mathrm{g} / \mathrm{L}$ \\
\hline 2-Hexanone & WA & & $\mathrm{U}$ & 10 & & NS & $\mu \mathrm{g} / \mathrm{L}$ \\
\hline 4-Methyl-2-pentanone & WA & . & $\mathrm{U}$ & 10 & & NS & $\mu \mathrm{g} / \mathrm{L}$ \\
\hline Acetone & WA & & $\mathrm{U}$ & 10 & & NS & $\mu \mathrm{g} / \mathrm{L}$ \\
\hline Acetonitrile (Methyl cyanide) & WA & & $\mathrm{U}$ & 20 & & NS & $\mu \mathrm{g} / \mathrm{L}$ \\
\hline Acrolein & WA & & $\mathrm{U}$ & 10 & & NS & $\mu \mathrm{g} / \mathrm{L}$ \\
\hline Acrylonitrile & WA & & $\mathbf{U}$ & 10 & & NS & $\mu g / L$ \\
\hline Allyl chloride & WA & & $\mathrm{U}$ & 100 & & NS & $\mu \mathrm{g} / \mathrm{L}$ \\
\hline Benzene & WA & & $\mathrm{U}$ & 5 & & 5 & $\mu \mathrm{g} / \mathrm{L}$ \\
\hline Bromodichloromethane & WA & & $\mathrm{U}$ & 5 & & NS & $\mu \mathrm{g} / \mathrm{L}$ \\
\hline Bromoform & WA & & $\mathrm{U}$ & 5 & & NS & $\mu \mathrm{g} / \mathrm{L}$ \\
\hline Carbon disulfide & WA & & $\mathbf{U}$ & 5 & & NS & $\mu \mathrm{g} / \mathrm{L}$ \\
\hline Carbon tetrachloride & WA & & $\mathrm{U}$ & 5 & & 5 & $\mu \mathrm{g} / \mathrm{L}$ \\
\hline Chlorobenzene & WA & & $\mathrm{U}$ & 5 & & 100 & $\mu \mathrm{g} / \mathrm{L}$ \\
\hline Chloroethane & WA & $\theta$ & $\mathrm{U}$ & 10 & & NS & $\mu \mathrm{g} / \mathrm{L}$ \\
\hline Chloroform & WA & & $\mathbf{J}$ & 2.03 & & 100 & $\mu \mathrm{g} / \mathrm{L}$ \\
\hline Chloroprene & WA & & $\mathrm{U}$ & 20 & & NS & $\mu \mathrm{g} / \mathrm{L}$ \\
\hline cis-1,3-Dichloropropene & WA & & $\mathbf{U}$ & 5 & & NS & $\mu \mathrm{g} / \mathrm{L}$ \\
\hline Dibromochloromethane & WA & & $\mathbf{U}$ & 5 & & NS & $\mu \mathrm{g} / \mathrm{L}$ \\
\hline Dichlorodifluoromethane & WA & & $\mathrm{J}$ & 4.46 & & NS & $\mu \mathrm{g} / \mathrm{L}$ \\
\hline Ethylbenzene & WA & & $\mathrm{U}$ & 5 & & 700 & $\mu g / L$ \\
\hline Isobutyl alcohol & WA & & $\mathrm{U}$ & 20 & & NS & $\mu \mathrm{g} / \mathrm{L}$ \\
\hline Methacrylonitrile & WA & & $\mathrm{U}$ & 20 & & NS & $\mu \mathrm{g} / \mathrm{L}$ \\
\hline Methyl bromide & WA & & $\mathbf{U}$ & 10 & & NS & $\mu \mathrm{g} / \mathrm{L}$ \\
\hline Methyl chloride & WA & & $\mathbf{U}$ & 10 & & NS & $\mu \mathrm{g} / \mathrm{L}$ \\
\hline Methyl ethyl ketone & WA & & $\mathbf{U}$ & 10 & & NS & $\mu \mathrm{g} / \mathrm{L}$ \\
\hline Methyl iodide & WA & & $\mathrm{U}$ & 10 & & NS & $\mu \mathrm{g} / \mathrm{L}$ \\
\hline Methylene bromide & WA & & $\mathrm{U}$ & 10 & & NS & $\mu g / L$ \\
\hline Methylene chloride & WA & & $\mathbf{U}$ & 5 & & 5 & $\mu \mathrm{g} / \mathrm{L}$ \\
\hline Propionitrile & WA & & $\mathrm{U}$ & 50 & & NS & $\mu \mathrm{g} / \mathrm{L}$ \\
\hline
\end{tabular}


FHB018B (cont'd)

\begin{tabular}{|c|c|c|c|c|c|c|c|c|}
\hline Analyte & Lab & Rep & Avg & Qualifier & Result & Acc & Standard & Units \\
\hline Styrene & WA & & & $\bar{U}$ & 5 & & 100 & $\mu \mathrm{g} / \mathrm{L}$ \\
\hline Tetrachloroethylene & WA & & & & 4.56 & & 5 & $\mu \mathrm{g} / \mathrm{L}$ \\
\hline Toluene & WA & & & $J$ & 1.13 & & 1000 & $\mu g / L$ \\
\hline trans-1,3-Dichloropropene & WA & & & $\mathrm{U}$ & 5 & & NS & $\mu \mathrm{g} / \mathrm{L}$ \\
\hline trans-1,4-Dichloro-2-butene & WA & & & $\mathrm{U}$ & 100 & & NS & $\mu \mathrm{g} / \mathrm{L}$ \\
\hline Trichloroethylene & WA & & & & 12.7 & & 5 & $\mu \mathrm{g} / \mathrm{L}$ \\
\hline Trichlorofluoromethane & WA & & & $\mathrm{U}$ & 5 & & NS & $\mu \mathrm{g} / \mathrm{L}$ \\
\hline Tritium & EMS & & & & 36800 & 360 & 20 & $\mathrm{pCi} / \mathrm{ml}$ \\
\hline Vinyl acetate & WA & & & U & 10 & & NS & $\mu \mathrm{g} / \mathrm{L}$ \\
\hline Vinyl chloride & WA & & & & 15.1 & & 2 & $\mu \mathrm{g} / \mathrm{L}$ \\
\hline Xylenes (total) & WA & & & $\mathrm{U}$ & 5 & & 10000 & $\mu \mathrm{g} / \mathrm{L}$ \\
\hline
\end{tabular}


FHB019

Field Measurements:

Sample Date: 08/25/94

Depth to Water: $3.2 \mathrm{ft}$ below TOC

Water Level Elevation: $210 \mathrm{msl}$

pH: 5.12

Conductivity: $41 \mu \mathrm{S} / \mathrm{cm}$

\begin{tabular}{|c|c|c|c|c|c|c|c|c|}
\hline Analyte & $\mathrm{Lab}$ & Rep & Avg & Qualifier & Result & Acc & Standard & Units \\
\hline 1,1,1,2-Tetrachloroethane & WA & & & $\bar{U}$ & 10 & & NS & $\mu \mathrm{g} / \mathrm{L}$ \\
\hline 1,1,1-Trichloroethane & WA & & & $\mathrm{U}$ & 5 & & 200 & $\mu \mathrm{g} / \mathrm{L}$ \\
\hline 1,1,2,2-Tetrachloroethane & WA & & & $\mathrm{U}$ & 5 & & NS & $\mu \mathrm{g} / \mathrm{L}$ \\
\hline 1,1,2-Trichloroethane & WA & & & $\mathbb{U}$ & 5 & & 5 & $\mu \mathrm{g} / \mathrm{L}$ \\
\hline 1,1-Dichloroethane & WA & & & $\mathrm{U}$ & 5 & & NS & $\mu \mathrm{g} / \mathrm{L}$ \\
\hline 1,1-Dichloroethylene & WA & & & $\mathrm{U}$ & 5 & & 7 & $\mu \mathrm{g} / \mathrm{L}$ \\
\hline 1,2,3-Trichloropropane & WA & & & U & 10 & & NS & $\mu \mathrm{g} / \mathrm{L}$ \\
\hline 1,2-Dibromo-3-chloropropane & WA & & & $\mathrm{U}$ & 20 & & 0.2 & $\mu \mathrm{g} / \mathrm{L}$ \\
\hline 1,2-Dibromoethane & WA & & & $\mathrm{U}$ & 20 & & NS & $\mu \mathrm{g} / \mathrm{L}$ \\
\hline 1,2-Dichloroethane & WA & & & $\mathrm{U}$ & 5 & & 5 & $\mu \mathrm{g} / \mathrm{L}$ \\
\hline 1,2-Dichloroethylene (total) & WA & & & & 67.2 & & 70 & $\mu \mathrm{g} / \mathrm{L}$ \\
\hline 1,2-Dichloropropane & WA & & & $\mathrm{U}$ & 5 & & 5 & $\mu \mathrm{g} / \mathrm{L}$ \\
\hline 2-Hexanone & WA & & & $\mathrm{U}$ & 10 & & NS & $\mu \mathrm{g} / \mathrm{L}$ \\
\hline 4-Methyl-2-pentanone & WA & & & U & 10 & & NS & $\mu \mathrm{g} / \mathrm{L}$ \\
\hline Acetone & WA & & & $\mathrm{U}$ & 10 & & NS & $\mu \mathrm{g} / \mathrm{L}$ \\
\hline Acetonitrile (Methyl cyanide) & WA & & & $\mathrm{U}$ & 20 & & NS & $\mu \mathrm{g} / \mathrm{L}$ \\
\hline Acrolein & WA & & & $\mathrm{U}$ & 10 & & NS & $\mu \mathrm{g} / \mathrm{L}$ \\
\hline Acrylonitrile & WA & & & $\mathrm{U}$ & 10 & & NS & $\mu \mathrm{g} / \mathrm{L}$ \\
\hline Allyl chloride & WA & & & $\mathrm{U}$ & 100 & & NS & $\mu \mathrm{g} / \mathrm{L}$ \\
\hline Benzene & WA & & & $\mathrm{U}$ & 5 & & 5 & $\mu \mathrm{g} / \mathrm{L}$ \\
\hline Bromodichloromethane & WA & & & $\mathrm{U}$ & 5 & & NS & $\mu \mathrm{g} / \mathrm{L}$ \\
\hline Bromoform & WA & & & $\mathrm{U}$ & 5 & & NS & $\mu \mathrm{g} / \mathrm{L}$ \\
\hline Carbon disulfide & WA & & & $\mathrm{U}$ & 5 & & NS & $\mu \mathrm{g} / \mathrm{L}$ \\
\hline Carbon tetrachloride & WA & & & $\mathrm{U}$ & 5 & & 5 & $\mu \mathrm{g} / \mathrm{L}$ \\
\hline Chlorobenzene & WA & & & $\mathrm{U}$ & 5 & & 100 & $\mu \mathrm{g} / \mathrm{L}$ \\
\hline Chloroethane & WA & & & $\mathrm{U}$ & 10 & & NS & $\mu \mathrm{g} / \mathrm{L}$ \\
\hline Chloroform & WA & & & $\mathrm{J}$ & 2.29 & & 100 & $\mu \mathrm{g} / \mathrm{L}$ \\
\hline Chloroprene & WA & & & $\mathrm{U}$ & 20 & & NS & $\mu \mathrm{g} / \mathrm{L}$ \\
\hline cis-1,3-Dichloropropene & WA & & & $\mathrm{U}$ & 5 & & NS & $\mu \mathrm{g} / \mathrm{L}$ \\
\hline Dibromochloromethane & WA & & & $\mathrm{U}$ & 5 & & NS & $\mu \mathrm{g} / \mathrm{L}$ \\
\hline Dichlorodifluoromethane & WA & & & $\mathbf{J}$ & 3.13 & & NS & $\mu \mathrm{g} / \mathrm{L}$ \\
\hline Ethylbenzene & WA & & & $\mathrm{U}$ & 5 & & 700 & $\mu \mathrm{g} / \mathrm{L}$ \\
\hline Isobutyl alcohol & WA & & & $\mathrm{U}$ & 20 & & NS & $\mu \mathrm{g} / \mathrm{L}$ \\
\hline Methacrylonitrile & WA & & & $\mathrm{U}$ & 20 & & NS & $\mu \mathrm{g} / \mathrm{L}$ \\
\hline Methyl bromide & WA & & & $\mathrm{U}$ & 10 & & NS & $\mu \mathrm{g} / \mathrm{L}$ \\
\hline Methyl chloride & WA & & & $\mathrm{U}$ & 10 & & NS & $\mu \mathrm{g} / \mathrm{L}$ \\
\hline Methyl ethyl ketone & WA & & & $\mathrm{U}$ & 10 & & NS & $\mu \mathrm{g} / \mathrm{L}$ \\
\hline Methyl iodide & WA & & & $\mathrm{U}$ & 10 & & NS & $\mu \mathrm{g} / \mathrm{L}$ \\
\hline Methylene bromide & WA & & & $\mathrm{U}$ & 10 & & NS & $\mu \mathrm{g} / \mathrm{L}$ \\
\hline Methylene chloride & WA & & & $\mathrm{U}$ & 5 & & 5 & $\mu \mathrm{g} / \mathrm{L}$ \\
\hline
\end{tabular}


FHB019 (cont'd)

\begin{tabular}{|c|c|c|c|c|c|c|c|}
\hline Analyte & Lab & Rep & Qualifier & Result & Acc & Standard & Units \\
\hline Propionitrile & WA & & $\bar{U}$ & 50 & & NS & $\mu \mathrm{g} / \mathrm{L}$ \\
\hline Styrene & WA & & $\mathrm{U}$ & 5 & & 100 & $\mu \mathrm{g} / \mathrm{L}$ \\
\hline Tetrachloroethylene & WA & & & 16.1 & & 5 & $\mu \mathrm{g} / \mathrm{L}$ \\
\hline Toluene & WA & & $\mathrm{U}$ & 5 & & 1000 & $\mu \mathrm{g} / \mathrm{L}$ \\
\hline trans-1,3-Dichloropropene & WA & & $\mathrm{U}$ & 5 & & NS & $\mu \mathrm{g} / \mathrm{L}$ \\
\hline trans-1,4-Dichloro-2-butene & WA & & $\mathrm{U}$ & 100 & & NS & $\mu \mathrm{g} / \mathrm{L}$ \\
\hline Trichloroethylene & WA & & & 34.8 & & 5 & $\mu \mathrm{g} / \mathrm{L}$ \\
\hline Trichlorofluoromethane & WA & & $\mathrm{U}$ & 5 & & NS & $\mu \mathrm{g} / \mathrm{L}$ \\
\hline Tritium & EMS & & & 31500 & 310 & 20 & $\mathrm{pCi} / \mathrm{ml}$ \\
\hline Vinyl acetate & WA & & $\mathrm{U}$ & 10 & & NS & $\mu \mathrm{g} / \mathrm{L}$ \\
\hline Vinyl chloride & WA & & $\mathrm{U}$ & 10 & & 2 & $\mu \mathrm{g} / \mathrm{L}$ \\
\hline Xylenes (total) & WA & & U & 5 & & 10000 & $\mu \mathrm{g} / \mathrm{L}$ \\
\hline
\end{tabular}


FHB020

Field Measurements:

Sample Date: 08/25/94

Depth to Water: $4.2 \mathrm{ft}$ below TOC

Water Level Elevation: $212 \mathrm{msl}$

pH: 4.92

Conductivity: $29 \mu \mathrm{S} / \mathrm{cm}$

\begin{tabular}{|c|c|c|c|c|c|c|c|c|}
\hline Analyte & Lab & Rep & Avg & Qualifier & Result & Acc & Standard & Units \\
\hline 1,1,1,2-Tetrachloroethane & WA & & & $\bar{U}$ & 10 & & NS & $\mu \mathrm{g} / \mathrm{L}$ \\
\hline 1,1,1-Trichloroethane & WA & & & $\mathrm{U}$ & 5 & & 200 & $\mu \mathrm{g} / \mathrm{L}$ \\
\hline 1,1,2,2-Tetrachloroethane & WA & & & $\mathrm{U}$ & 5 & & NS & $\mu \mathrm{g} / \mathrm{L}$ \\
\hline 1,1,2-Trichloroethane & WA & & & $\mathrm{U}$ & 5 & & 5 & $\mu \mathrm{g} / \mathrm{L}$ \\
\hline 1,1-Dichloroethane & WA & & & $\mathrm{U}$ & 5 & & NS & $\mu g / L$ \\
\hline 1,1-Dichloroethylene & WA & & & $\mathrm{U}$ & 5 & & 7 & $\mu \mathrm{g} / \mathrm{L}$ \\
\hline 1,2,3-Trichloropropane & WA & & & $\mathrm{U}$ & 10 & & NS & $\mu \mathrm{g} / \mathrm{L}$ \\
\hline 1,2-Dibromo-3-chloropropane & WA & & & U & 20 & & 0.2 & $\mu \mathrm{g} / \mathrm{L}$ \\
\hline 1,2-Dibromoethane & WA & & & $\mathrm{U}$ & 20 & & NS & $\mu \mathrm{g} / \mathrm{L}$ \\
\hline 1,2-Dichloroethane & WA & & & U & 5 & & 5 & $\mu \mathrm{g} / \mathrm{L}$ \\
\hline 1,2-Dichloroethylene (total) & WA & & & $\mathrm{U}$ & 5 & & 70 & $\mu g / L$ \\
\hline 1,2-Dichloropropane & WA & & & $\mathrm{U}$ & 5 & & 5 & $\mu \mathrm{g} / \mathrm{L}$ \\
\hline 2-Hexanone & WA & & & U & 10 & & NS & $\mu g / L$ \\
\hline 4-Methyl-2-pentanone & WA & & & $\mathrm{U}$ & 10 & & NS & $\mu \mathrm{g} / \mathrm{L}$ \\
\hline Acetone & WA & & & $\mathrm{U}$ & 10 & & NS & $\mu \mathrm{g} / \mathrm{L}$ \\
\hline Acetonitrile (Methyl cyanide) & WA & & & $\mathrm{U}$ & 20 & & NS & $\mu \mathrm{g} / \mathrm{L}$ \\
\hline Acrolein & WA & & & $\mathrm{U}^{\mathrm{Y}}$ & 10 & & NS & $\mu \mathrm{g} / \mathrm{L}$ \\
\hline Acrylonitrile & WA & & & $\mathbf{U}$ & 10 & & NS & $\mu \mathrm{g} / \mathrm{L}$ \\
\hline Allyl chloride & WA & & & $\mathrm{U}$ & 100 & & NS & $\mu g / L$ \\
\hline Benzene & WA & & & $\mathrm{U}$ & 5 & & 5 & $\mu \mathrm{g} / \mathrm{L}$ \\
\hline Bromodichloromethane & WA & & & $\mathrm{U}$ & 5 & & NS & $\mu \mathrm{g} / \mathrm{L}$ \\
\hline Bromoform & WA & & & $\mathrm{U}$ & 5 & & NS & $\mu g / L$ \\
\hline Carbon disulfide & WA & & & $\mathbf{U}$ & 5 & & NS & $\mu \mathrm{g} / \mathrm{L}$ \\
\hline Carbon tetrachloride & WA & & & $\mathrm{U}$ & 5 & & 5 & $\mu \mathrm{g} / \mathrm{L}$ \\
\hline Chlorobenzene & WA & & & $\mathrm{U}$ & 5 & & 100 & $\mu \mathrm{g} / \mathrm{L}$ \\
\hline Chloroethane & WA & & & $\mathrm{U}$ & 10 & & NS & $\mu \mathrm{g} / \mathrm{L}$ \\
\hline Chloroform & WA & & & $\mathrm{U}$ & 5 & & 100 & $\mu g / L$ \\
\hline Chloroprene & WA & & & $\mathrm{U}$ & 20 & & NS & $\mu \mathrm{g} / \mathrm{L}$ \\
\hline cis-1,3-Dichloropropene & WA & & & $\mathrm{U}$ & 5 & & NS & $\mu \mathrm{g} / \mathrm{L}$ \\
\hline Dibromochloromethane & WA & & & $\mathrm{U}$ & 5 & & NS & $\mu \mathrm{g} / \mathrm{L}$ \\
\hline Dichlorodifluoromethane & WA & & & $U$ & 10 & & NS & $\mu \mathrm{g} / \mathrm{L}$ \\
\hline Ethylbenzene & WA & & & $\mathrm{U}$ & 5 & & 700 & $\mu \mathrm{g} / \mathrm{L}$ \\
\hline Isobutyl alcohol & WA & & & $\mathrm{U}$ & 20 & & NS & $\mu g / L$ \\
\hline Methacrylonitrile & WA & & & $\mathbf{U}$ & 20 & & NS & $\mu \mathrm{g} / \mathrm{L}$ \\
\hline Methyl bromide & WA & & & $\mathrm{U}$ & 10 & & NS & $\mu \mathrm{g} / \mathrm{L}$ \\
\hline Methyl chloride & WA & & & $\mathrm{U}$ & 10 & & NS & $\mu \mathrm{g} / \mathrm{L}$ \\
\hline Methyl ethyl ketone & WA & & & $\mathbf{U}$ & 10 & & NS & $\mu \mathrm{g} / \mathrm{L}$ \\
\hline Methyl iodide & WA & & & $\mathrm{U}$ & 10 & & NS & $\mu \mathrm{g} / \mathrm{L}$ \\
\hline Methylene bromide & WA & & & $\mathrm{U}$ & 10 & & NS & $\mu \mathrm{g} / \mathrm{L}$ \\
\hline Methylene chloride & WA & & & $\mathrm{J}$ & 1.1 & & 5 & $\mu \mathrm{g} / \mathrm{L}$ \\
\hline
\end{tabular}


FHB020 (cont'd)

\begin{tabular}{|c|c|c|c|c|c|c|c|c|}
\hline Analyte & Lab & Rep & Avg & Qualifier & Result & Acc & Standard & Units \\
\hline Propionitrile & WA & & & $\mathrm{U}$ & 50 & & NS & $\mu \mathrm{g} / \mathrm{L}$ \\
\hline Styrene & WA & & & $\mathrm{U}$ & 5 & & 100 & $\mu \mathrm{g} / \mathrm{L}$ \\
\hline Tetrachloroethylene & WA & & & $\mathrm{U}$ & 5 & & 5 & $\mu g / L$ \\
\hline Toluene & WA & & & $\mathrm{U}$ & 5 & & 1000 & $\mu \mathrm{g} / \mathrm{L}$ \\
\hline trans-1,3-Dichloropropene & WA & & & $\mathrm{U}$ & 5 & & NS & $\mu \mathrm{g} / \mathrm{L}$ \\
\hline trans-1,4-Dichloro-2-butene & WA & & & $\mathrm{U}$ & 100 & & NS & $\mu \mathrm{g} / \mathrm{L}$ \\
\hline Trichloroethylene & WA & & & $\mathrm{U}$ & 5 & & 5 & $\mu \mathrm{g} / \mathrm{L}$ \\
\hline Trichlorofluoromethane & WA & & & $\mathrm{U}$ & 5 & & NS & $\mu \mathrm{g} / \mathrm{L}$ \\
\hline Tritium & EMS & & & & 18.3 & 0.61 & 20 & $\mathrm{pCi} / \mathrm{ml}$ \\
\hline Vinyl acetate & WA & & & $\mathrm{U}$ & 10 & & NS & $\mu \mathrm{g} / \mathrm{L}$ \\
\hline Vinyl chloride & WA & & & $\mathrm{U}$ & 10 & & 2 & $\mu \mathrm{g} / \mathrm{L}$ \\
\hline Xylenes (total) & WA & & & $\mathrm{U}$ & 5 & & 10000 & $\mu \mathrm{g} / \mathrm{L}$ \\
\hline
\end{tabular}




\section{FHB020B}

Field Measurements:

Sample Date: 08/25/94

pH: 5.62

Conductivity: $66 \mu \mathrm{S} / \mathrm{cm}$

\begin{tabular}{|c|c|c|c|c|c|c|c|c|}
\hline Analyte & Lab & Rep & Avg & Qualifier & Result & Acc & Standard & Units \\
\hline 1,1,1,2-Tetrachloroethane & WA & & & $\bar{U}$ & 10 & & NS & $\mu \mathrm{g} / \mathrm{L}$ \\
\hline 1,1,1-Trichloroethane & WA & & & $\mathrm{U}$ & 5 & & 200 & $\mu \mathrm{g} / \mathrm{L}$ \\
\hline 1,1,2,2-Tetrachloroethane & WA & & & $\mathrm{U}$ & 5 & & NS & $\mu \mathrm{g} / \mathrm{L}$ \\
\hline 1,1,2-Trichloroethane & WA & & & $U$ & 5 & & 5 & $\mu \mathrm{g} / \mathrm{L}$ \\
\hline 1,1-Dichloroethane & WA & & & U & 5 & & NS & $\mu \mathrm{g} / \mathrm{L}$ \\
\hline 1,1-Dichloroethylene & WA & & & $U$ & 5 & & 7 & $\mu \mathrm{g} / \mathrm{L}$ \\
\hline 1,2,3-Trichloropropane & WA & & & $\mathrm{U}$ & 10 & & NS & $\mu \mathrm{g} / \mathrm{L}$ \\
\hline 1,2-Dibromo-3-chloropropane & WA & & & $\mathrm{U}$ & 20 & & 0.2 & $\mu \mathrm{g} / \mathrm{L}$ \\
\hline 1,2-Dibromoethane & WA & & & $U$ & 20 & & NS & $\mu \mathrm{g} / \mathrm{L}$ \\
\hline 1,2-Dichloroethane & WA & & & $\mathrm{U}$ & 5 & & 5 & $\mu \mathrm{g} / \mathrm{L}$ \\
\hline 1,2-Dichloroethylene (total) & WA & & & $\mathrm{U}$ & 5 & & 70 & $\mu \mathrm{g} / \mathrm{L}$ \\
\hline 1,2-Dichloropropane & WA & & & $\mathrm{U}$ & 5 & & 5 & $\mu \mathrm{g} / \mathrm{L}$ \\
\hline 2-Hexanone & WA & & & $\mathrm{U}$ & 10 & & NS & $\mu \mathrm{g} / \mathrm{L}$ \\
\hline 4-Methyl-2-pentanone & WA & & & $\mathrm{U}$ & 10 & & NS & $\mu \mathrm{g} / \mathrm{L}$ \\
\hline Acetone & WA & & & JV & 7.13 & & NS & $\mu \mathrm{g} / \mathrm{L}$ \\
\hline Acetonitrile (Methyl cyanide) & WA & & & $\mathrm{U}$ & 20 & & NS & $\mu \mathrm{g} / \mathrm{L}$ \\
\hline Acrolein & WA & & & $U$ & 10 & & NS & $\mu \mathrm{g} / \mathrm{L}$ \\
\hline Acrylonitrile & WA & & & $\mathrm{U}$ & 10 & & NS & $\mu \mathrm{g} / \mathrm{L}$ \\
\hline Allyl chloride & WA & & & $\mathrm{U}$ & 100 & & NS & $\mu \mathrm{g} / \mathrm{L}$ \\
\hline Benzene & WA & & & $\mathrm{U}$ & 5 & & 5 & $\mu \mathrm{g} / \mathrm{L}$ \\
\hline Bromodichloromethane & WA & & & $\mathrm{U}$ & 5 & & NS & $\mu \mathrm{g} / \mathrm{L}$ \\
\hline Bromoform & WA & & & $\mathrm{U}$ & 5 & & NS & $\mu \mathrm{g} / \mathrm{L}$ \\
\hline Carbon disulfide & WA & & & $\mathrm{U}$ & 5 & & NS & $\mu \mathrm{g} / \mathrm{L}$ \\
\hline Carbon tetrachloride & WA & & & $\mathrm{U}$ & 5 & & 5 & $\mu \mathrm{g} / \mathrm{L}$ \\
\hline Chlorobenzene & WA & & & $\mathrm{U}$ & 5 & & 100 & $\mu \mathrm{g} / \mathrm{L}$ \\
\hline Chloroethane & WA & & & $\mathrm{U}$ & 10 & & NS & $\mu \mathrm{g} / \mathrm{L}$ \\
\hline Chloroform & WA & & & $\mathrm{U}$ & 5 & & 100 & $\mu \mathrm{g} / \mathrm{L}$ \\
\hline Chloroprene & WA & & & $\mathrm{U}$ & 20 & & NS & $\mu \mathrm{g} / \mathrm{L}$ \\
\hline cis-1,3-Dichloropropene & WA & & & $\mathrm{U}$ & 5 & & NS & $\mu \mathrm{g} / \mathrm{L}$ \\
\hline Dibromochloromethane & WA & & & U & 5 & & NS & $\mu \mathrm{g} / \mathrm{L}$ \\
\hline Dichlorodifluoromethane & WA & & & U & 10 & & NS & $\mu g / L$ \\
\hline Ethylbenzene & WA & & & $\mathbf{U}$ & 5 & & 700 & $\mu \mathrm{g} / \mathrm{L}$ \\
\hline Isobutyl alcohol & WA & & & $\mathbf{U}$ & 20 & & NS & $\mu \mathrm{g} / \mathrm{L}$ \\
\hline Methacrylonitrile & WA & & & U & 20 & & NS & $\mu \mathrm{g} / \mathrm{L}$ \\
\hline Methyl bromide & WA & & & $\mathrm{U}$ & 10 & & NS & $\mu \mathrm{g} / \mathrm{L}$ \\
\hline Methyl chloride & WA & & & $\mathrm{U}$ & 10 & & NS & $\mu \mathrm{g} / \mathrm{L}$ \\
\hline Methyl ethyl ketone & WA & & & $\mathrm{U}$ & 10 & & NS & $\mu \mathrm{g} / \mathrm{L}$ \\
\hline Methyl iodide & WA & & & $\mathrm{U}$ & 10 & & NS & $\mu \mathrm{g} / \mathrm{L}$ \\
\hline Methylene bromide & WA & & & $\mathrm{U}$ & 10 & & NS & $\mu \mathrm{g} / \mathrm{L}$ \\
\hline Methylene chloride & WA & & & $\mathbf{J}$ & 1.09 & & 5 & $\mu \mathrm{g} / \mathrm{L}$ \\
\hline Propionitrile & WA & & & $\mathrm{U}$ & 50 & & NS & $\mu \mathrm{g} / \mathrm{L}$ \\
\hline
\end{tabular}


FHB020B

\begin{tabular}{|c|c|c|c|c|c|c|c|c|}
\hline Analyte & Lab & Rep & Avg & Qualifier & Result & Acc & Standard & Units \\
\hline Styrene & WA & & & $\bar{U}$ & 5 & & 100 & $\mu \mathrm{g} / \mathrm{L}$ \\
\hline Tetrachloroethylene & WA & & & $\mathrm{U}$ & 5 & & 5 & $\mu \mathrm{g} / \mathrm{L}$ \\
\hline Toluene & WA & & & $\mathrm{U}$ & 5 & & 1000 & $\mu \mathrm{g} / \mathrm{L}$ \\
\hline trans-1,3-Dichloropropene & WA & & & $\mathrm{U}$ & 5 & & NS & $\mu g / L$ \\
\hline trans-1,4-Dichloro-2-butene & WA & & & $\mathrm{U}$ & 100 & & NS & $\mu \mathrm{g} / \mathrm{L}$ \\
\hline Trichloroethylene & WA & & & $\mathrm{U}$ & 5 & & 5 & $\mu \mathrm{g} / \mathrm{L}$ \\
\hline Trichlorofluoromethane & WA & & & $\mathrm{U}$ & 5 & & NS & $\mu \mathrm{g} / \mathrm{L}$ \\
\hline Tritium & EMS & & & & 34.9 & 0.85 & 20 & $\mathrm{pCi} / \mathrm{ml}$ \\
\hline Vinyl acetate & WA & & & $\mathrm{U}$ & 10 & & NS & $\mu \mathrm{g} / \mathrm{L}$ \\
\hline Vinyl chloride & WA & & & $\mathrm{U}$ & 10 & & 2 & $\mu \mathrm{g} / \mathrm{L}$ \\
\hline Xylenes (total) & WA & & & $\mathrm{U}$ & 5 & & 10000 & $\mu \mathrm{g} / \mathrm{L}$ \\
\hline
\end{tabular}


FVA001

(Volatile Trip Blank)

Field Measurements:

Sample Date: 08/25/94

\begin{tabular}{|c|c|c|c|c|c|c|c|}
\hline Analyte & $\mathrm{Lab}$ & Avg & Qualifier & Result & Acc & Standard & Units \\
\hline 1,1,1,2-Tetrachloroethane & WA & & $\bar{U}$ & 10 & & NS & $\mu \mathrm{g} / \mathrm{L}$ \\
\hline 1,1,1-Trichloroethane & WA & & $\mathrm{U}$ & 5 & & 200 & $\mu \mathrm{g} / \mathrm{L}$ \\
\hline 1,1,2,2-Tetrachloroethane & WA & & $\mathbf{U}$ & 5 & & NS & $\mu \mathrm{g} / \mathrm{L}$ \\
\hline 1,1,2-Trichloroethane & WA & & $\mathbf{U}$ & 5 & & 5 & $\mu \mathrm{g} / \mathrm{L}$ \\
\hline 1,1-Dichloroethane & WA & & $\mathrm{U}$ & 5 & & NS & $\mu \mathrm{g} / \mathrm{L}$ \\
\hline 1,1-Dichloroethylene & WA & & U & 5 & & 7 & $\mu \mathrm{g} / \mathrm{L}$ \\
\hline 1,2,3-Trichloropropane & WA & & $\mathrm{U}$ & 10 & & NS & $\mu \mathrm{g} / \mathrm{L}$ \\
\hline 1,2-Dibromo-3-chloropropane & WA & & $\mathrm{U}$ & 20 & & 0.2 & $\mu \mathrm{g} / \mathrm{L}$ \\
\hline 1,2-Dibromoethane & WA & & $\mathrm{U}$ & 20 & & NS & $\mu \mathrm{g} / \mathrm{L}$ \\
\hline 1,2-Dichloroethane & WA & & $\mathrm{U}$ & 5 & & 5 & $\mu \mathrm{g} / \mathrm{L}$ \\
\hline 1,2-Dichloropropane & WA & & $\mathrm{U}$ & 5 & & 5 & $\mu \mathrm{g} / \mathrm{L}$ \\
\hline 2-Hexanone & WA & & $\mathbf{U}$ & 10 & & NS & $\mu \mathrm{g} / \mathrm{L}$ \\
\hline 4-Methyl-2-pentanone & WA & & $\mathbf{U}$ & 10 & & NS & $\mu \mathrm{g} / \mathrm{L}$ \\
\hline Acetone & WA & & JV & 7.96 & & NS & $\mu \mathrm{g} / \mathrm{L}$ \\
\hline Acetonitrile (Methyl cyanide) & WA & & $\mathrm{U}$ & 20 & & NS & $\mu \mathrm{g} / \mathrm{L}$ \\
\hline Acrolein & WA & & $\mathrm{U}$ & 10 & & NS & $\mu \mathrm{g} / \mathrm{L}$ \\
\hline Acrylonitrile & WA & & $\mathbf{U}$ & 10 & & NS & $\mu \mathrm{g} / \mathrm{L}$ \\
\hline Allyl chloride & WA & & $U$ & 100 & & NS & $\mu \mathrm{g} / \mathrm{L}$ \\
\hline Benzene & WA & & $\mathrm{U}$ & 5 & & 5 & $\mu \mathrm{g} / \mathrm{L}$ \\
\hline Bromodichloromethane & WA & & $\mathbf{U}$ & 5 & & NS & $\mu g / L$ \\
\hline Bromoform & WA & & $\mathbf{U}$ & 5 & & NS & $\mu \mathrm{g} / \mathrm{L}$ \\
\hline Carbon disulfide & WA & & $\mathbf{U}$ & 5 & & NS & $\mu \mathrm{g} / \mathrm{L}$ \\
\hline Carbon tetrachloride & WA & & $\mathbf{U}$ & 5 & & 5 & $\mu \mathrm{g} / \mathrm{L}$ \\
\hline Chlorobenzene & WA & & $\mathrm{U}$ & 5 & & 100 & $\mu \mathrm{g} / \mathrm{L}$ \\
\hline Chloroethane & WA & & $\mathrm{U}$ & 10 & & NS & $\mu \mathrm{g} / \mathrm{L}$ \\
\hline Chloroform & WA & & $\mathbf{U}$ & 5 & & 100 & $\mu \mathrm{g} / \mathrm{L}$ \\
\hline Chloroprene & WA & & $\mathbf{U}$ & 20 & & NS & $\mu \mathrm{g} / \mathrm{L}$ \\
\hline cis-1,3-Dichloropropene & WA & & $\mathbf{U}$ & 5 & & NS & $\mu \mathrm{g} / \mathrm{L}$ \\
\hline Dibromochloromethane & WA & & $\mathrm{U}$ & 5 & & NS & $\mu \mathrm{g} / \mathrm{L}$ \\
\hline Dichlorodifluoromethane & WA & & $\mathrm{U}$ & 10 & & NS & $\mu \mathrm{g} / \mathrm{L}$ \\
\hline Ethylbenzene & WA & & $\mathrm{U}$ & 5 & & 700 & $\mu \mathrm{g} / \mathrm{L}$ \\
\hline Isobutyl alcohol & WA & & $\mathbf{U}$ & 20 & & NS & $\mu \mathrm{g} / \mathrm{L}$ \\
\hline Methacrylonitrile & WA & & $\mathrm{U}$ & 20 & & NS & $\mu \mathrm{g} / \mathrm{L}$ \\
\hline Methyl bromide & WA & & $\mathbf{U}$ & 10 & & NS & $\mu \mathrm{g} / \mathrm{L}$ \\
\hline Methyl chloride & WA & & J & 3.7 & & NS & $\mu \mathrm{g} / \mathrm{L}$ \\
\hline Methyl ethyl ketone & WA & & $\mathrm{U}$ & 10 & & NS & $\mu \mathrm{g} / \mathrm{L}$ \\
\hline Methyl iodide & WA & & $U$ & 10 & & NS & $\mu \mathrm{g} / \mathrm{L}$ \\
\hline Methylene bromide & WA & & $\mathrm{U}$ & 10 & & NS & $\mu \mathrm{g} / \mathrm{L}$ \\
\hline Methylene chloride & WA & & $\mathrm{U}$ & 5 & & 5 & $\mu \mathrm{g} / \mathrm{L}$ \\
\hline Propionitrile & WA & & $\mathrm{U}$ & 50 & & NS & $\mu \mathrm{g} / \mathrm{L}$ \\
\hline
\end{tabular}


FVA001 (cont'd)

\begin{tabular}{|c|c|c|c|c|c|c|c|c|}
\hline Analyte & $\mathrm{Lab}$ & Rep & Avg & Qualifier & Result & Acc & Standard & Units \\
\hline Styrene & WA & & & $\bar{U}$ & 5 & & 100 & $\mu \mathrm{g} / \mathrm{L}$ \\
\hline Tetrachloroethylene & WA & & & $\mathrm{U}$ & 5 & & 5 & $\mu \mathrm{g} / \mathrm{L}$ \\
\hline Toluene & WA & & & $\mathrm{U}$ & 5 & & 1000 & $\mu \mathrm{g} / \mathrm{L}$ \\
\hline trans-1,3-Dichloropropene & WA & & & $\mathrm{U}$ & 5 & & NS & $\mu \mathrm{g} / \mathrm{L}$ \\
\hline trans-1,4-Dichloro-2-butene & WA & & & $\mathrm{U}$ & 100 & & NS & $\mu \mathrm{g} / \mathrm{L}$ \\
\hline Trichloroethylene & WA & & & $\mathrm{U}$ & 5 & & 5 & $\mu \mathrm{g} / \mathrm{L}$ \\
\hline Trichlorofluoromethane & WA & & & $\mathrm{U}$ & 5 & & NS & $\mu \mathrm{g} / \mathrm{L}$ \\
\hline Vinyl acetate & WA & & & $\mathrm{U}$ & 10 & & NS & $\mu \mathrm{g} / \mathrm{L}$ \\
\hline Vinyl chloride & WA & & & $\mathrm{U}$ & 10 & & 2 & $\mu \mathrm{g} / \mathrm{L}$ \\
\hline Xylenes (total) & WA & & & $\mathrm{U}$ & 5 & & 10000 & $\mu \mathrm{g} / \mathrm{L}$ \\
\hline
\end{tabular}


QA002

(Trip Blank)

Field Measurements:

Sample Date: 08/25/94

\begin{tabular}{|c|c|c|c|c|c|c|c|}
\hline Analyte & $\mathrm{Lab}$ & Rep & Qualifier & Result & Acc & Standard & Units \\
\hline 1,1,1,2-Tetrachloroethane & WA & & $\mathrm{U}$ & 10 & & NS & $\mu \mathrm{g} / \mathrm{L}$ \\
\hline 1,1,1-Trichloroethane & WA & & $\mathrm{U}$ & 5 & & 200 & $\mu \mathrm{g} / \mathrm{L}$ \\
\hline 1,1,2,2-Tetrachloroethane & WA & & $\mathrm{U}$ & 5 & & NS & $\mu \mathrm{g} / \mathrm{L}$ \\
\hline 1,1,2-Trichloroethane & WA & & $\mathrm{U}$ & 5 & & 5 & $\mu \mathrm{g} / \mathrm{L}$ \\
\hline 1,1-Dichloroethane & WA & & $\mathrm{U}$ & 5 & & NS & $\mu \mathrm{g} / \mathrm{L}$ \\
\hline 1,1-Dichloroethylene & WA & & $\mathrm{U}$ & 5 & & 7 & $\mu \mathrm{g} / \mathrm{L}$ \\
\hline 1,2,3-Trichloropropane & WA & & $\mathrm{U}$ & 10 & & NS & $\mu \mathrm{g} / \mathrm{L}$ \\
\hline 1,2-Dibromo-3-chloropropane & WA & & $U$ & 20 & & 0.2 & $\mu \mathrm{g} / \mathrm{L}$ \\
\hline 1,2-Dibromoethane & WA & & $\mathrm{U}$ & 20 & & NS & $\mu \mathrm{g} / \mathrm{L}$ \\
\hline 1,2-Dichloroethane & WA & & $\mathrm{U}$ & 5 & & 5 & $\mu \mathrm{g} / \mathrm{L}$ \\
\hline 1,2-Dichloropropane & WA & & $\mathrm{U}$ & 5 & & 5 & $\mu \mathrm{g} / \mathrm{L}$ \\
\hline 2-Hexanone & WA & & $\mathrm{U}$ & 10 & & NS & $\mu \mathrm{g} / \mathrm{L}$ \\
\hline 4-Methyl-2-pentanone & WA & & $\mathrm{U}$ & 10 & & NS & $\mu \mathrm{g} / \mathrm{L}$ \\
\hline Acetone & WA & & $\mathrm{U}$ & 10 & & NS & $\mu \mathrm{g} / \mathrm{L}$ \\
\hline Acetonitrile (Methyl cyanide) & WA & & $\mathrm{U}$ & 20 & & NS & $\mu \mathrm{g} / \mathrm{L}$ \\
\hline Acrolein & WA & & $\mathrm{U}$ & 10 & & NS & $\mu \mathrm{g} / \mathrm{L}$ \\
\hline Acrylonitrile & WA & & $\mathbf{U}$ & 10 & & NS & $\mu \mathrm{g} / \mathrm{L}$ \\
\hline Allyl chloride & WA & & $\mathbf{U}$ & 100 & & NS & $\mu g / L$ \\
\hline Benzene & WA & & $\mathbf{U}$ & 5 & & 5 & $\mu \mathrm{g} / \mathrm{L}$ \\
\hline Bromodichloromethane & WA & & $\mathrm{U}$ & 5 & & NS & $\mu \mathrm{g} / \mathrm{L}$ \\
\hline Bromoform & WA & & $U$ & 5 & & NS & $\mu \mathrm{g} / \mathrm{L}$ \\
\hline Carbon disulfide & WA & & $\mathrm{U}$ & 5 & & NS & $\mu \mathrm{g} / \mathrm{L}$ \\
\hline Carbon tetrachloride & WA & & $\mathrm{U}$ & 5 & & 5 & $\mu \mathrm{g} / \mathrm{L}$ \\
\hline Chlorobenzene & WA & & $\mathrm{U}$ & 5 & & 100 & $\mu \mathrm{g} / \mathrm{L}$ \\
\hline Chloroethane & WA & & $\mathrm{U}$ & 10 & & NS & $\mu \mathrm{g} / \mathrm{L}$ \\
\hline Chloroform & WA & & $\mathrm{U}$ & 5 & & 100 & $\mu \mathrm{g} / \mathrm{L}$ \\
\hline Chloroprene & WA & & $\mathrm{U}$ & 20 & & NS & $\mu \mathrm{g} / \mathrm{L}$ \\
\hline cis-1,3-Dichloropropene & WA & & $\mathbf{U}$ & 5 & & NS & $\mu \mathrm{g} / \mathrm{L}$ \\
\hline Dibromochloromethane & WA & & $\mathrm{U}$ & 5 & & NS & $\mu \mathrm{g} / \mathrm{L}$ \\
\hline Dichlorodifluoromethane & WA & & $\mathrm{U}$ & 10 & & NS & $\mu \mathrm{g} / \mathrm{L}$ \\
\hline Ethylbenzene & WA & & $\mathrm{U}$ & 5 & & 700 & $\mu \mathrm{g} / \mathrm{L}$ \\
\hline Isobutyl alcohol & WA & & $\mathrm{U}$ & 20 & & NS & $\mu \mathrm{g} / \mathrm{L}$ \\
\hline Methacrylonitrile & WA & & $\mathrm{U}$ & 20 & & NS & $\mu \mathrm{g} / \mathrm{L}$ \\
\hline Methyl bromide & WA & & $U$ & 10 & & NS & $\mu \mathrm{g} / \mathrm{L}$ \\
\hline Methyl chloride & WA & & & 13.4 & & NS & $\mu \mathrm{g} / \mathrm{L}$ \\
\hline Methyl ethyl ketone & WA & & $U$ & 10 & & NS & $\mu \mathrm{g} / \mathrm{L}$ \\
\hline Methyl iodide & WA & & $\mathrm{U}$ & 10 & & NS & $\mu \mathrm{g} / \mathrm{L}$ \\
\hline Methylene bromide & WA & & $\mathbf{U}$ & 10 & & NS & $\mu \mathrm{g} / \mathrm{L}$ \\
\hline Methylene chloride & WA & & $\mathrm{U}$ & 5 & & 5 & $\mu \mathrm{g} / \mathrm{L}$ \\
\hline Propionitrile & WA & & $\mathbf{U}$ & 50 & & NS & $\mu \mathrm{g} / \mathrm{L}$ \\
\hline
\end{tabular}


QA002 (cont'd)

\begin{tabular}{|c|c|c|c|c|c|c|c|c|}
\hline Analyte & Lab & Rep & Avg & Qualifier & Result & Acc & Standard & Units \\
\hline$\overline{\text { Styrene }}$ & WA & & & $\overline{\mathrm{U}}$ & 5 & & 100 & $\mu \mathrm{g} / \mathrm{L}$ \\
\hline Tetrachloroethylene & WA & & & $\mathrm{U}$ & 5 & & 5 & $\mu \mathrm{g} / \mathrm{L}$ \\
\hline Toluene & WA & & & $\mathrm{U}$ & 5 & & 1000 & $\mu \mathrm{g} / \mathrm{L}$ \\
\hline trans-1,3-Dichloropropene & WA & & & $\mathrm{U}$ & 5 & & NS & $\mu \mathrm{g} / \mathrm{L}$ \\
\hline trans-1,4-Dichloro-2-butene & WA & & & $\mathrm{U}$ & 100 & & NS & $\mu \mathrm{g} / \mathrm{L}$ \\
\hline Trichloroethylene & WA & & & U & 5 & & 5 & $\mu \mathrm{g} / \mathrm{L}$ \\
\hline Trichlorofluoromethane & WA & & & $\mathrm{U}$ & 5 & & NS & $\mu \mathrm{g} / \mathrm{L}$ \\
\hline Tritium & EMS & & & U & 1.1 & 0.37 & 20 & $\mathrm{pCi} / \mathrm{ml}$ \\
\hline Vinyl acetate & WA & & & $\mathrm{U}$ & 10 & & NS & $\mu \mathrm{g} / \mathrm{L}$ \\
\hline Vinyl chloride & WA & & & $\mathrm{U}$ & 10 & & 2 & $\mu \mathrm{g} / \mathrm{L}$ \\
\hline Xylenes (total) & WA & & & $\mathrm{U}$ & 5 & & 10000 & $\mu \mathrm{g} / \mathrm{L}$ \\
\hline
\end{tabular}


QA003

(Trip Blank)

Field Measurements:

Sample Date: 08/25/94

\begin{tabular}{|c|c|c|c|c|c|c|c|c|}
\hline Analyte & $\mathrm{Lab}$ & Rep & Avg & Qualifier & Result & Acc & Standard & Units \\
\hline 1,1,1,2-Tetrachloroethane & WA & & & $\bar{U}$ & 10 & & NS & $\mu \mathrm{g} / \mathrm{L}$ \\
\hline 1,1,1-Trichloroethane & WA & & & $\mathrm{U}$ & 5 & & 200 & $\mu \mathrm{g} / \mathrm{L}$ \\
\hline 1,1,2,2-Tetrachloroethane & WA & & & $\mathrm{U}$ & 5 & & NS & $\mu \mathrm{g} / \mathrm{L}$ \\
\hline 1,1,2-Trichloroethane & WA & & & $\mathrm{U}$ & 5 & & 5 & $\mu \mathrm{g} / \mathrm{L}$ \\
\hline 1,1-Dichloroethane & WA & & & U & 5 & & NS & $\mu g / L$ \\
\hline 1,1-Dichloroethylene & WA & & & $\mathrm{U}$ & 5 & & 7 & $\mu \mathrm{g} / \mathrm{L}$ \\
\hline 1,2,3-Trichloropropane & WA & & & $\mathrm{U}$ & 10 & & NS & $\mu \mathrm{g} / \mathrm{L}$ \\
\hline 1,2-Dibromo-3-chloropropane & WA & & & $\mathrm{U}$ & 20 & & 0.2 & $\mu \mathrm{g} / \mathrm{L}$ \\
\hline 1,2-Dibromoethane & WA & & & $\mathrm{U}$ & 20 & & NS & $\mu \mathrm{g} / \mathrm{L}$ \\
\hline 1,2-Dichloroethane & WA & & & $\mathrm{U}$ & 5 & & 5 & $\mu \mathrm{g} / \mathrm{L}$ \\
\hline 1,2-Dichloropropane & WA & & & $\mathrm{U}$ & 5 & & 5 & $\mu \mathrm{g} / \mathrm{L}$ \\
\hline 2-Hexanone & WA & & & $\mathrm{U}$ & 10 & & NS & $\mu \mathrm{g} / \mathrm{L}$ \\
\hline 4-Methyl-2-pentanone & WA & & & $\mathrm{U}$ & 10 & & NS & $\mu \mathrm{g} / \mathrm{L}$ \\
\hline Acetone & WA & & & JV & 7.48 & & NS & $\mu \mathrm{g} / \mathrm{L}$ \\
\hline Acetonitrile (Methyl cyanide) & WA & & & $\mathrm{U}$ & 20 & & NS & $\mu \mathrm{g} / \mathrm{L}$ \\
\hline Acrolein & WA & & & $\mathrm{U}$ & 10 & & NS & $\mu \mathrm{g} / \mathrm{L}$ \\
\hline Acrylonitrile & WA & & & $\mathrm{U}$ & 10 & & NS & $\mu \mathrm{g} / \mathrm{L}$ \\
\hline Allyl chloride & WA & & & $\mathrm{U}$ & 100 & & NS & $\mu \mathrm{g} / \mathrm{L}$ \\
\hline Benzene & WA & & & $\mathrm{U}$ & 5 & & 5 & $\mu \mathrm{g} / \mathrm{L}$ \\
\hline Bromodichloromethane & WA & & & $\mathrm{U}$ & 5 & & NS & $\mu \mathrm{g} / \mathrm{L}$ \\
\hline Bromoform & WA & & & $\mathrm{U}$ & 5 & & NS & $\mu \mathrm{g} / \mathrm{L}$ \\
\hline Carbon disulfide & WA & & & $\mathrm{U}$ & 5 & & NS & $\mu \mathrm{g} / \mathrm{L}$ \\
\hline Carbon tetrachloride & WA & & & $\mathrm{U}$ & 5 & & 5 & $\mu \mathrm{g} / \mathrm{L}$ \\
\hline Chlorobenzene & WA & & & U & 5 & & 100 & $\mu \mathrm{g} / \mathrm{L}$ \\
\hline Chloroethane & WA & & & $\mathrm{U}$ & 10 & & NS & $\mu \mathrm{g} / \mathrm{L}$ \\
\hline Chloroform & WA & & & $\mathbf{U}$ & 5 & & 100 & $\mu g / L$ \\
\hline Chloroprene & WA & & & $\mathrm{U}$ & 20 & & NS & $\mu \mathrm{g} / \mathrm{L}$ \\
\hline cis-1,3-Dichloropropene & WA & & & $U$ & 5 & & NS & $\mu \mathrm{g} / \mathrm{L}$ \\
\hline Dibromochloromethane & WA & & & $\mathrm{U}$ & 5 & & NS & $\mu \mathrm{g} / \mathrm{L}$ \\
\hline Dichlorodifluoromethane & WA & & & $\mathbf{U}$ & 10 & & NS & $\mu \mathrm{g} / \mathrm{L}$ \\
\hline Ethylbenzene & WA & & & $\mathrm{U}$ & 5 & & 700 & $\mu g / L$ \\
\hline Isobutyl alcohol & WA & & & $\mathrm{U}$ & 20 & & NS & $\mu \mathrm{g} / \mathrm{L}$ \\
\hline Methacrylonitrile & WA & & & U & 20 & & NS & $\mu \mathrm{g} / \mathrm{L}$ \\
\hline Methyl bromide & WA & & & U & 10 & & NS & $\mu \mathrm{g} / \mathrm{L}$ \\
\hline Methyl chloride & WA & & & & 17.2 & & NS & $\mu \mathrm{g} / \mathrm{L}$ \\
\hline Methyl ethyl ketone & WA & & & $\mathrm{U}$ & 10 & & NS & $\mu \mathrm{g} / \mathrm{L}$ \\
\hline Methyl iodide & WA & & & $\mathbf{U}$ & 10 & & NS & $\mu \mathrm{g} / \mathrm{L}$ \\
\hline Methylene bromide & WA & & & $\mathrm{U}$ & 10 & & NS & $\mu \mathrm{g} / \mathrm{L}$ \\
\hline Methylene chloride & WA & & & $\mathrm{U}$ & 5 & & 5 & $\mu \mathrm{g} / \mathrm{L}$ \\
\hline Propionitrile & WA & & & $\mathrm{U}$ & 50 & & NS & $\mu \mathrm{g} / \mathrm{L}$ \\
\hline
\end{tabular}


QA003 (cont'd)

\begin{tabular}{|c|c|c|c|c|c|c|c|c|}
\hline Analyte & Lab & Rep & Avg & Qualifier & Result & Acc & Standard & Units \\
\hline Styrene & $\overline{W A}$ & & & $\overline{\mathrm{U}}$ & $\overline{5}$ & & 100 & $\mu \mathrm{g} / \mathrm{L}$ \\
\hline Tetrachloroethylene & WA & & & $\mathrm{U}$ & 5 & & 5 & $\mu \mathrm{g} / \mathrm{L}$ \\
\hline Toluene & WA & & & $\mathrm{U}$ & 5 & & 1000 & $\mu \mathrm{g} / \mathrm{L}$ \\
\hline trans-1,3-Dichloropropene & WA & & & $\mathrm{U}$ & 5 & & NS & $\mu \mathrm{g} / \mathrm{L}$ \\
\hline trans-1,4-Dichloro-2-butene & WA & & & $\mathrm{U}$ & 100 & & NS & $\mu g / L$ \\
\hline Trichloroethylene & WA & & & $\mathrm{U}$ & 5 & & 5 & $\mu \mathrm{g} / \mathrm{L}$ \\
\hline Trichlorofluoromethane & WA & & & $\mathrm{U}$ & 5 & & NS & $\mu \mathrm{g} / \mathrm{L}$ \\
\hline Tritium 1 & EMS & & & & 62000 & 545 & 20 & $\mathrm{pCi} / \mathrm{ml}$ \\
\hline Vinyl acetate & WA & & & $\mathrm{U}$ & 10 & & NS & $\mu \mathrm{g} / \mathrm{L}$ \\
\hline Vinyl chloride & WA & & & $U$ & 10 & & 2 & $\mu \mathrm{g} / \mathrm{L}$ \\
\hline Xylenes (total) & WA & & & U & 5 & & 10000 & $\mu \mathrm{g} / \mathrm{L}$ \\
\hline
\end{tabular}

1Blind Replicate Sample collected at FHB018. 
Appendix $B$

Information on Electronic Data Diskettes 
INFORMATION PROVIDED TO ESS ON ELECTRONINC DATA DISKETTES

\begin{tabular}{|lll|}
\hline Sample name & Laboratory sample number & Accuracy \\
Chain of custody number & Laboratory replicate & Number of dilutions \\
Sample date & Testname & Dilution factor \\
Received date & Extraction/digestion method & Instrument \\
Extraction date & Analysis method & Analyst \\
Extraction time & Detection limit & Nominal concentration \\
Analysis date & Result qualifier & \\
Analysis time & Analysis qualifier & \\
Analysis batch & Bias & \\
Laboratory code & Analytical result & \\
\end{tabular}


